\title{
Sustainable wastewater management
}

\author{
Citation for published version (APA):
}

Oteng-Peprah, M. (2020). Sustainable wastewater management: exploring the option of greywater reuse in a developing country - Ghana. [Doctoral Thesis, Maastricht University]. ProefschriftMaken. https://doi.org/10.26481/dis.20200916mo

Document status and date:

Published: 01/01/2020

DOI:

10.26481/dis.20200916mo

Document Version:

Publisher's PDF, also known as Version of record

\section{Please check the document version of this publication:}

- A submitted manuscript is the version of the article upon submission and before peer-review. There can be important differences between the submitted version and the official published version of record.

People interested in the research are advised to contact the author for the final version of the publication, or visit the DOI to the publisher's website.

- The final author version and the galley proof are versions of the publication after peer review.

- The final published version features the final layout of the paper including the volume, issue and page numbers.

Link to publication

\footnotetext{
General rights rights.

- You may freely distribute the URL identifying the publication in the public portal. please follow below link for the End User Agreement:

www.umlib.nl/taverne-license

Take down policy

If you believe that this document breaches copyright please contact us at:

repository@maastrichtuniversity.nl

providing details and we will investigate your claim.
}

Copyright and moral rights for the publications made accessible in the public portal are retained by the authors and/or other copyright owners and it is a condition of accessing publications that users recognise and abide by the legal requirements associated with these

- Users may download and print one copy of any publication from the public portal for the purpose of private study or research.

- You may not further distribute the material or use it for any profit-making activity or commercial gain

If the publication is distributed under the terms of Article $25 \mathrm{fa}$ of the Dutch Copyright Act, indicated by the "Taverne" license above, 


\section{Sustainable wastewater management;}

\section{exploring the option of greywater reuse}

in a developing country - Ghana
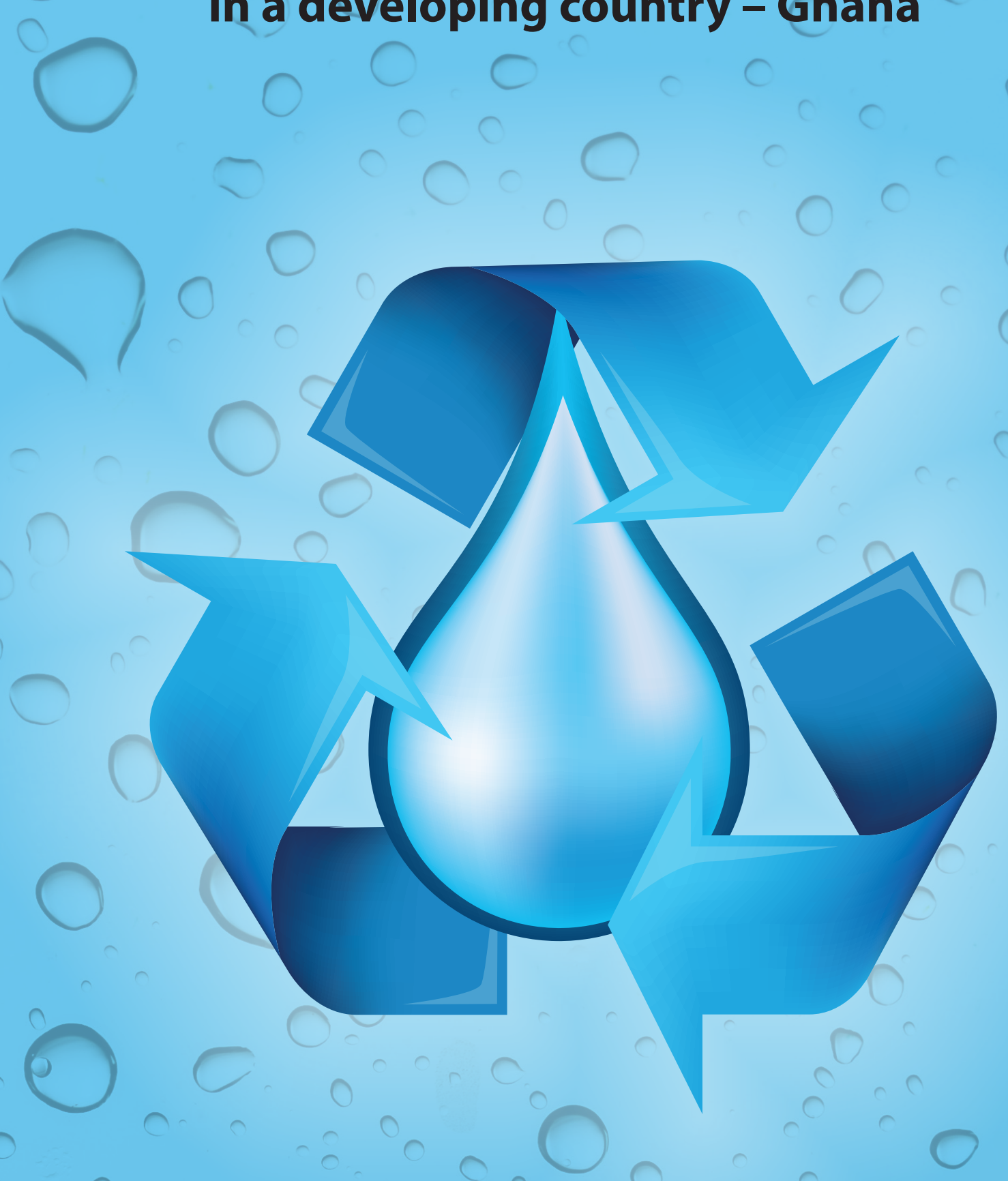

Michael Oteng-Peprah 

Sustainable wastewater management; exploring the option of greywater reuse in a developing country - Ghana

\author{
Michael Oteng-Peprah
}




\section{Supervisor}

Prof. dr. Nanne de Vries

\section{Co-supervisor}

Prof. Mike Agbesi Acheampong

\section{Assessment Committee}

Prof. dr. R.M.M. Crutzen, (Chairman)

Prof. dr. M. Honing

Prof. dr. R.P.M. Kemp

Prof. dr. ir. P.N.L. Lens, IHE Delft Institute for Water Education;

Dr. R.J.W. Meulepas, Wetsus, European Centre of Excellence for Sustainable Water Technology, Leeuwarden.

The research presented in this dissertation was conducted at the School of Public Health and Primary Care: CAPHRI, Department of Health Promotion of the Maastricht University. CAPHRI participates in the research school CARE, Netherlands School of Primary Care Research.

This research presented in this dissertation was supported by the Dutch Ministry for Foreign Affairs (through NUFFIC, project NICHE 194-01 [grant number CF9419]) and University of Cape Coast (UCC) Ghana. Opinions expressed and conclusions arrived at, are those of the authors and are not necessarily to be attributed to UCC.

ISBN: 978-94-6380-932-0 
Sustainable wastewater management; exploring the option of greywater reuse in a developing country - Ghana

\author{
Dissertation \\ to obtain the degree of Doctor at Maastricht University, \\ on the authority of the Rector Magnificus, \\ Prof. Dr. Rianne M. Letschert, \\ In accordance with the decision of the Board of Deans, \\ to be defended in public on
}

Wednesday the $16^{\text {th }}$ of September 2020

At 10:00am

by

MICHAEL OTENG-PEPRAH 



\section{Table of Contents}

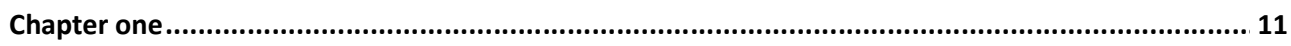

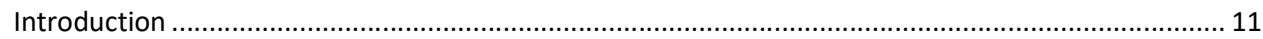

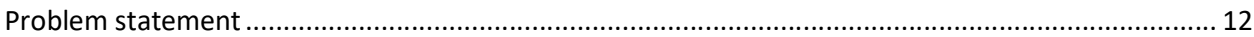

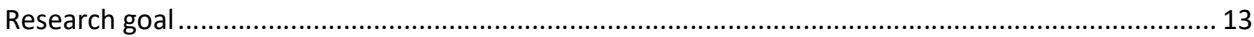

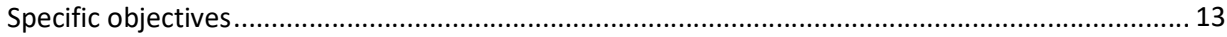

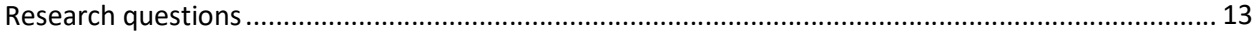

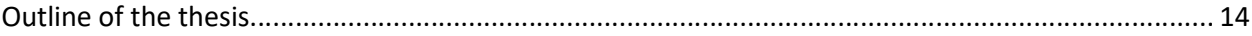

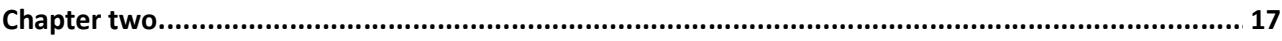

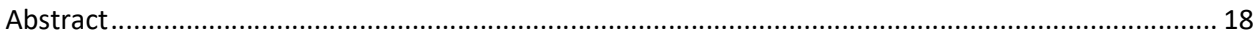

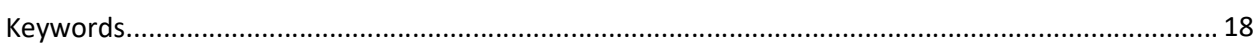

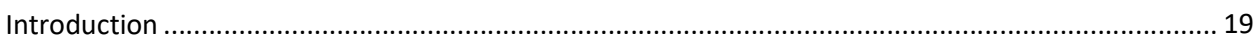

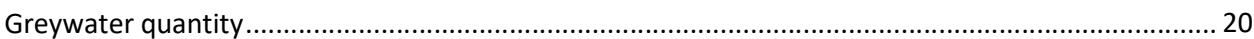

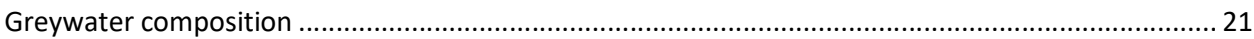

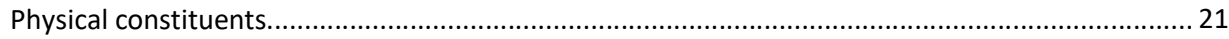

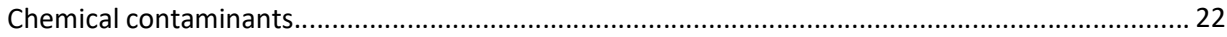

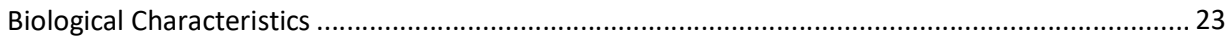

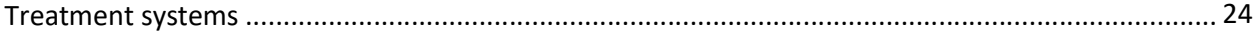

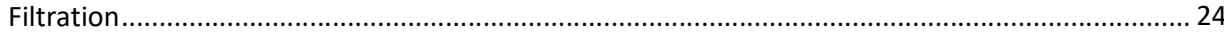

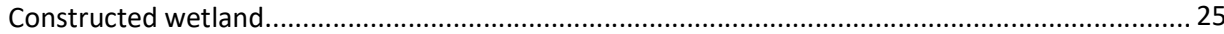

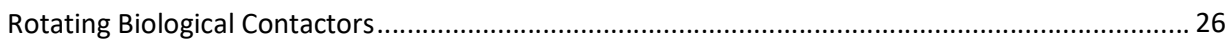

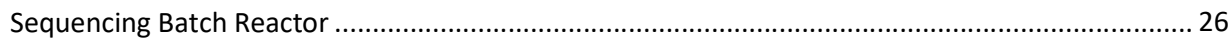

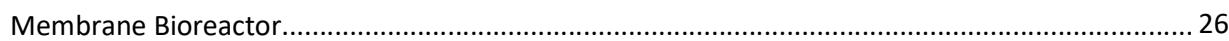

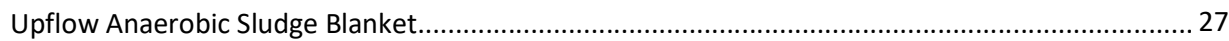

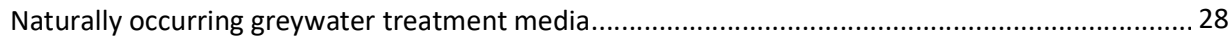

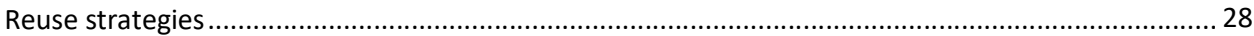

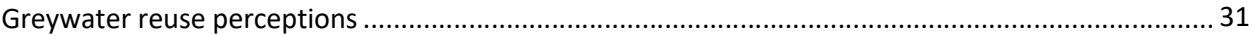

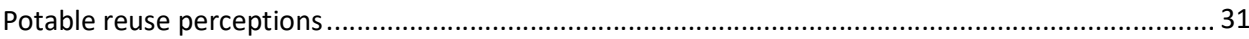

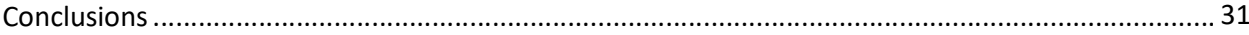

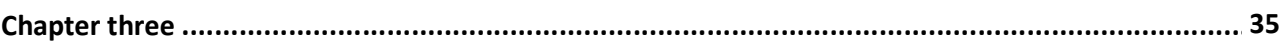

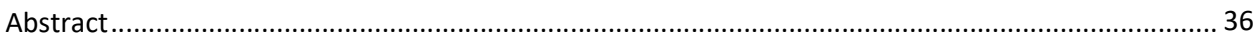

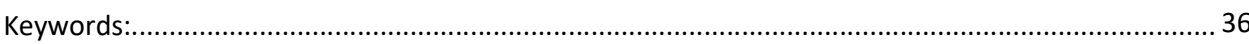




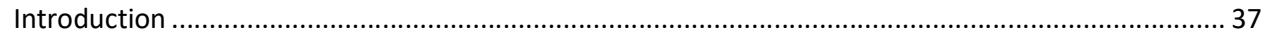

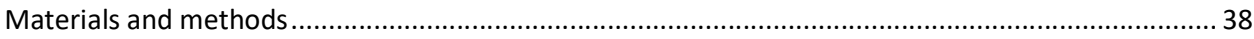

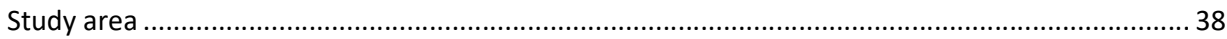

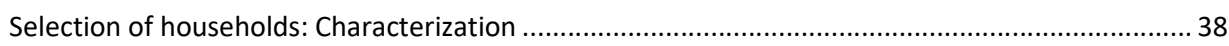

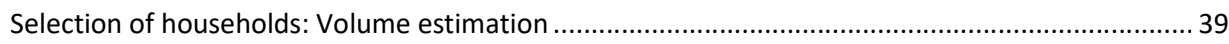

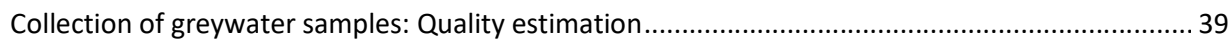

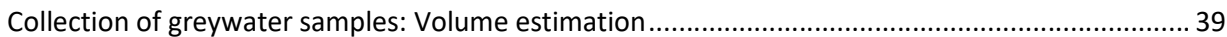

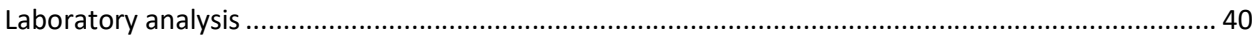

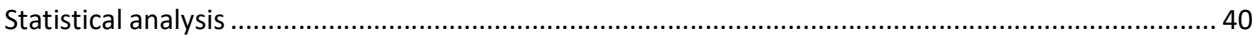

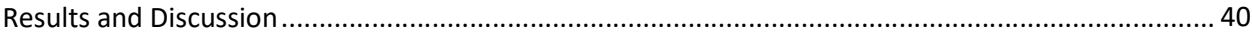

Water consumption and greywater volume generation .................................................... 40

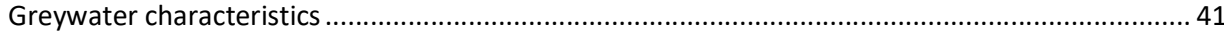

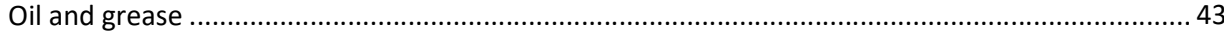

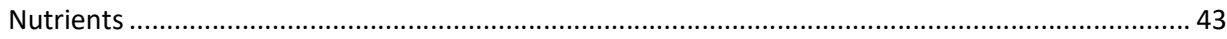

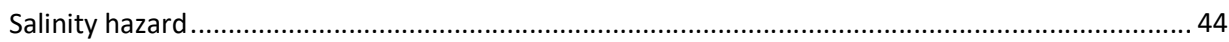

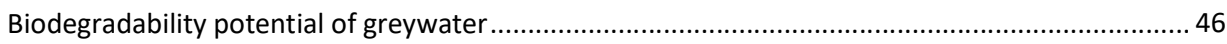

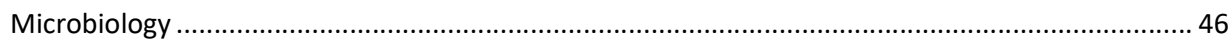

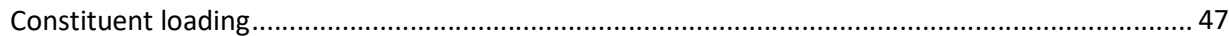

Evaluation of factors influencing greywater quality (Principal Component Analysis) .....................48

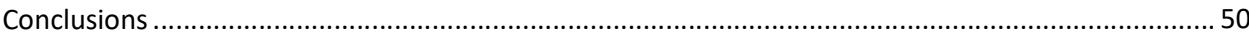

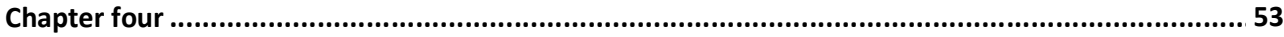

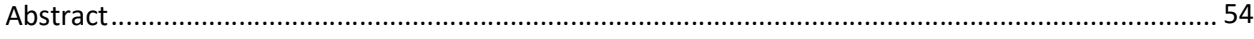

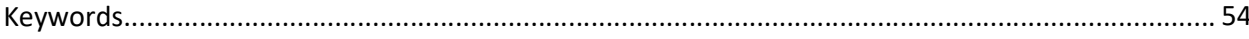

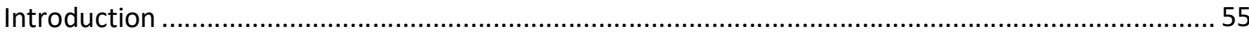

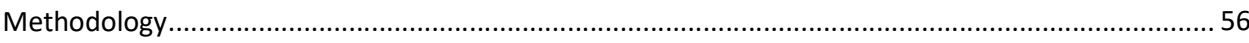

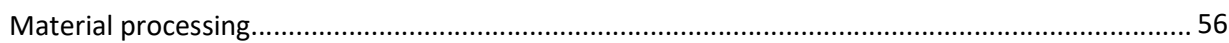

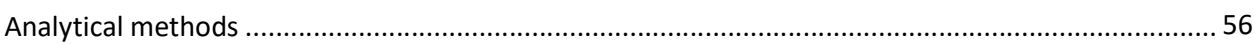

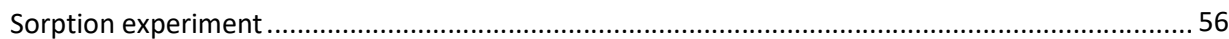

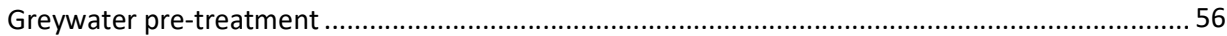

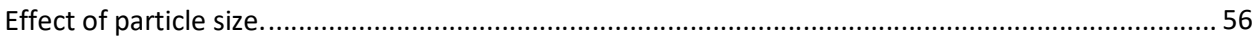

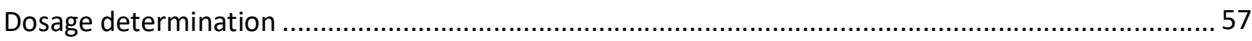

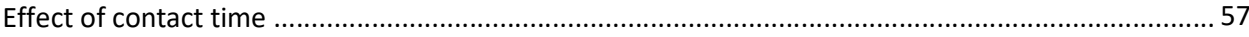

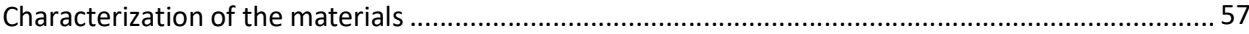


Calculations

Mathematical equations and models of adsorption isotherms ................................................... 57

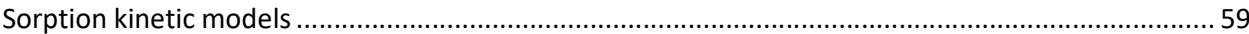

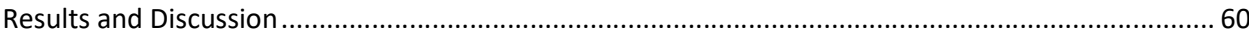

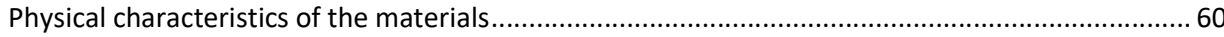

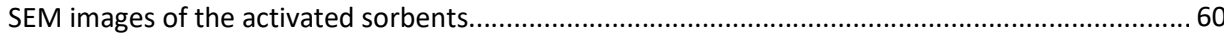

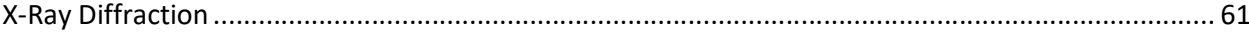

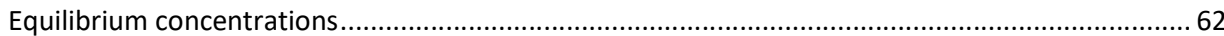

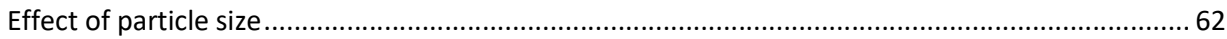

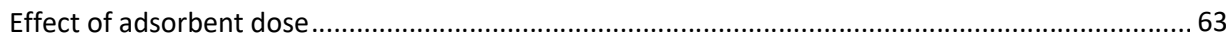

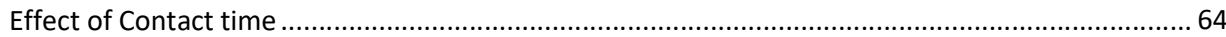

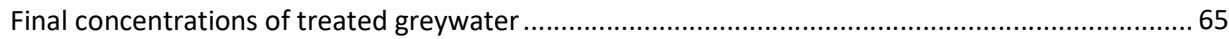

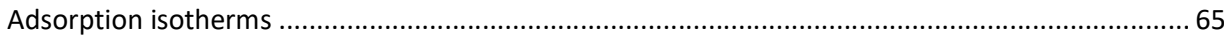

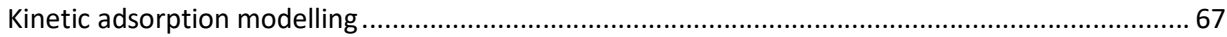

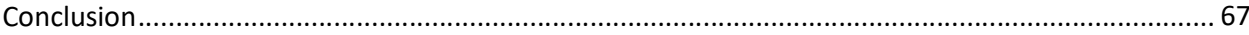

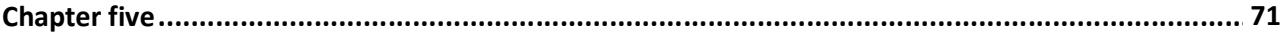

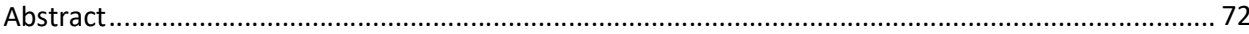

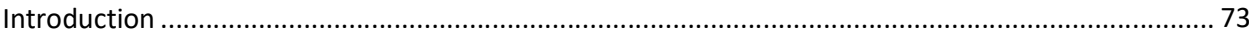

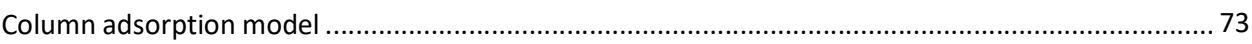

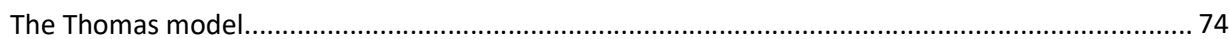

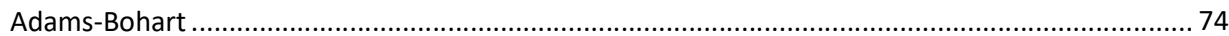

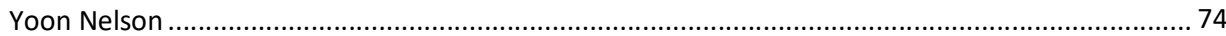

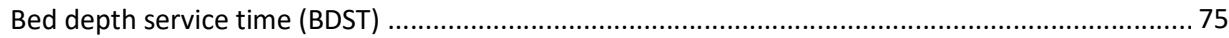

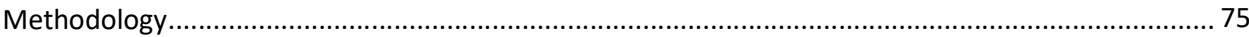

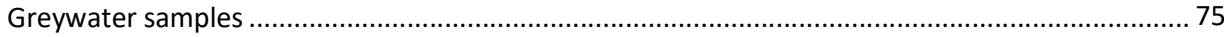

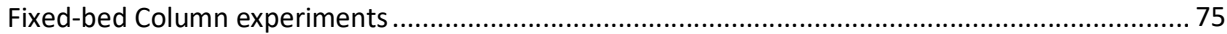

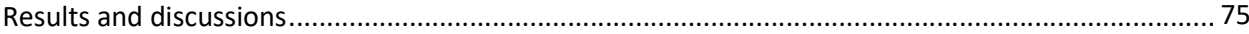

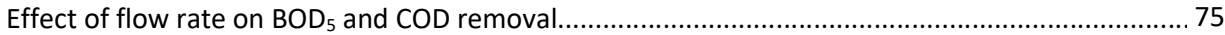

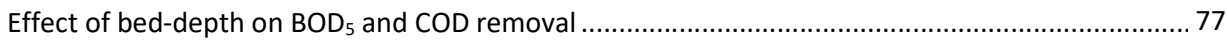

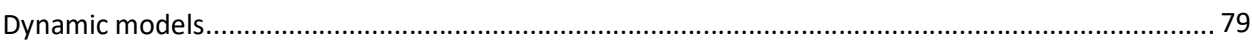

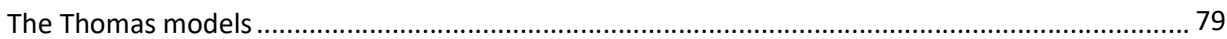

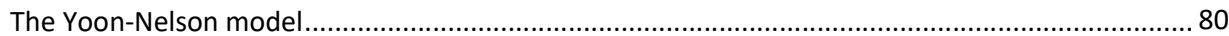

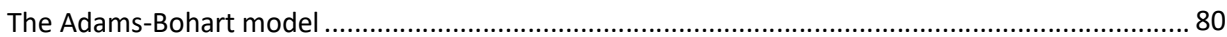




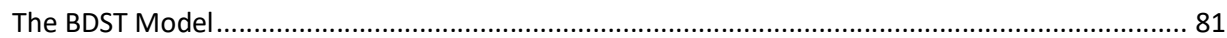

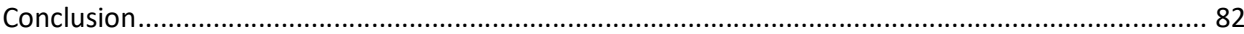

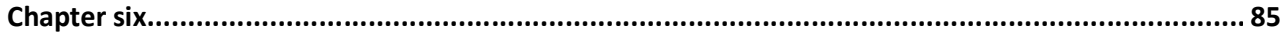

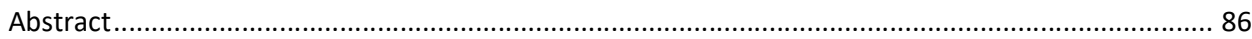

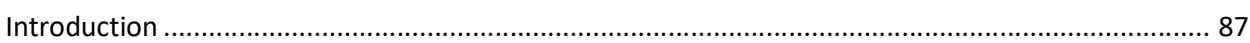

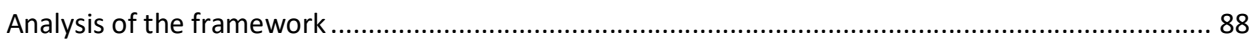

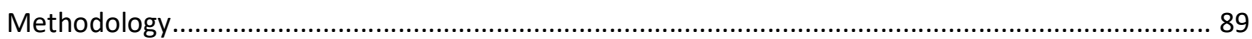

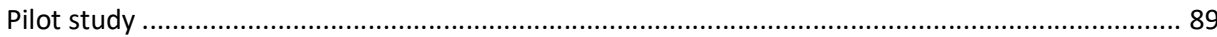

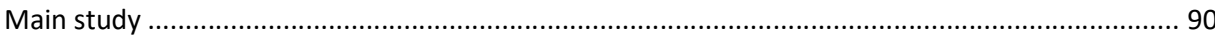

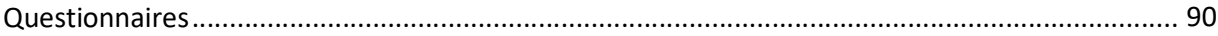

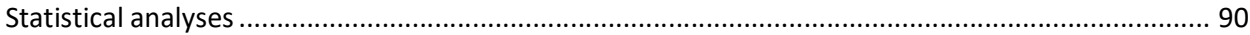

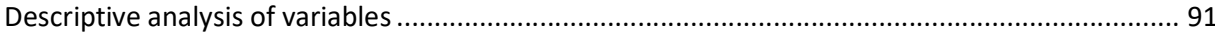

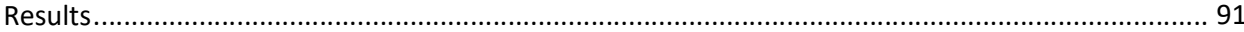

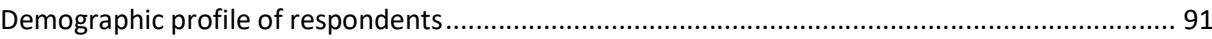

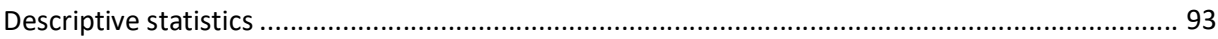

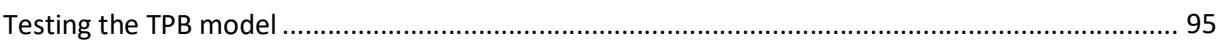

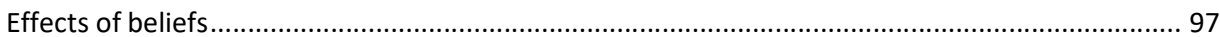

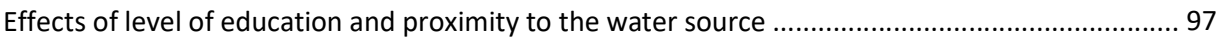

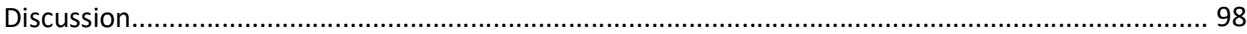

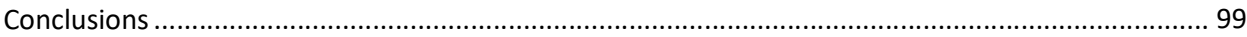

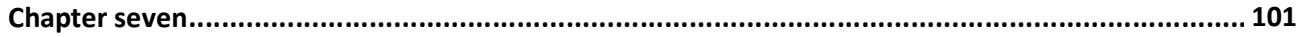

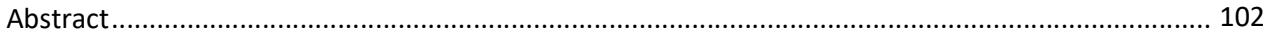

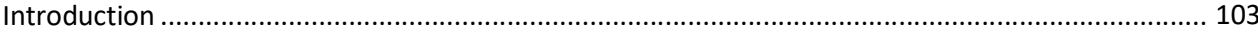

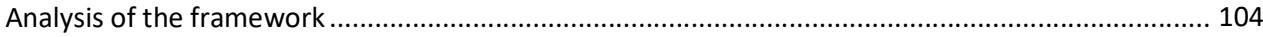

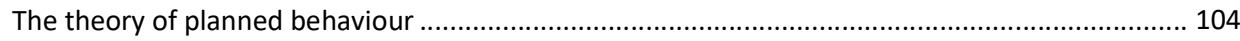

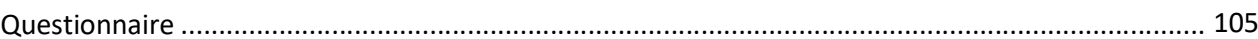

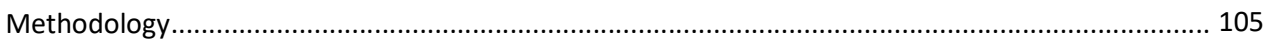

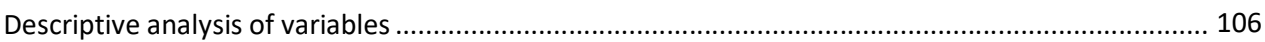

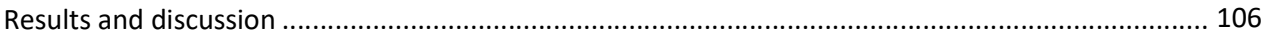

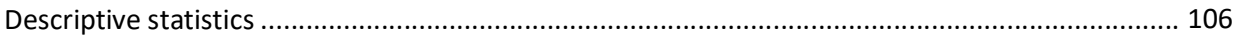

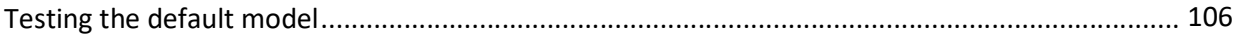

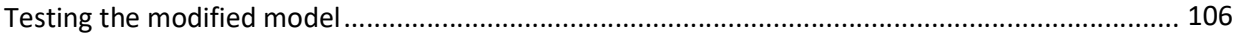

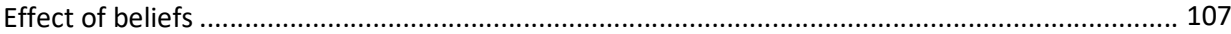




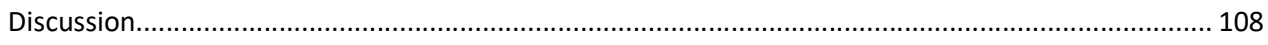

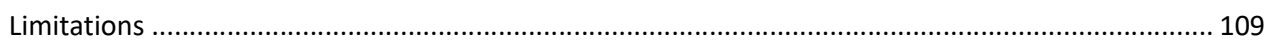

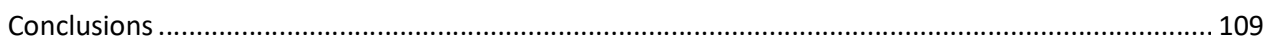

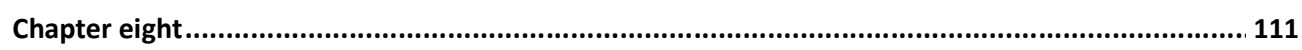

General discussions............................................................................................................. 111

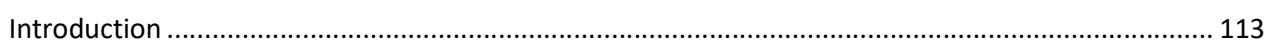

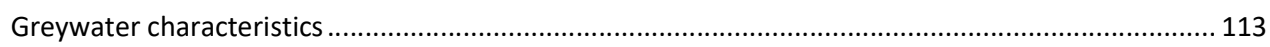

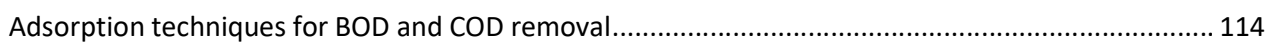

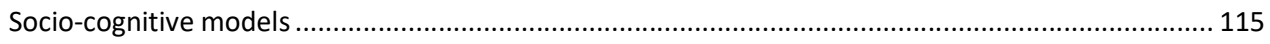

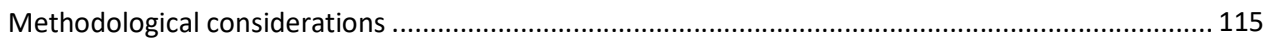

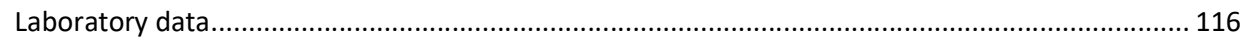

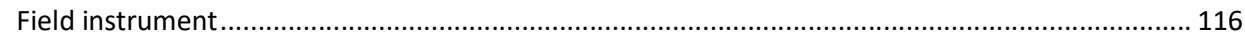

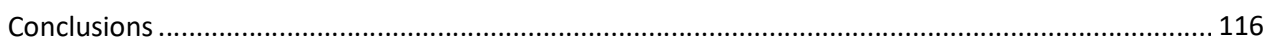

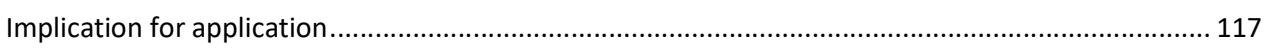

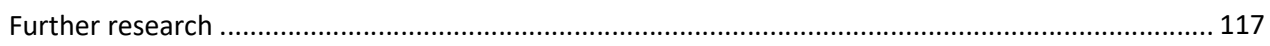

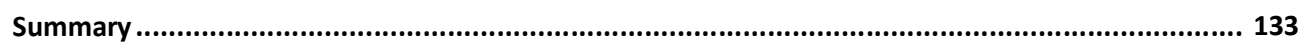

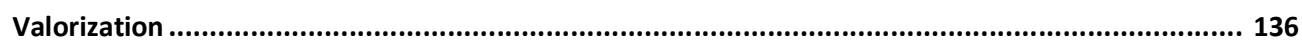

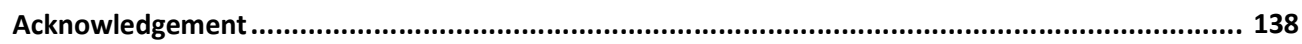

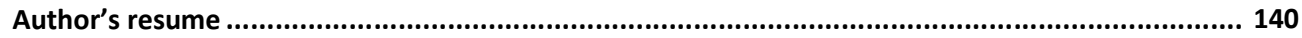

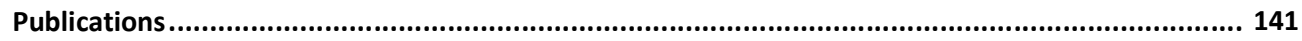



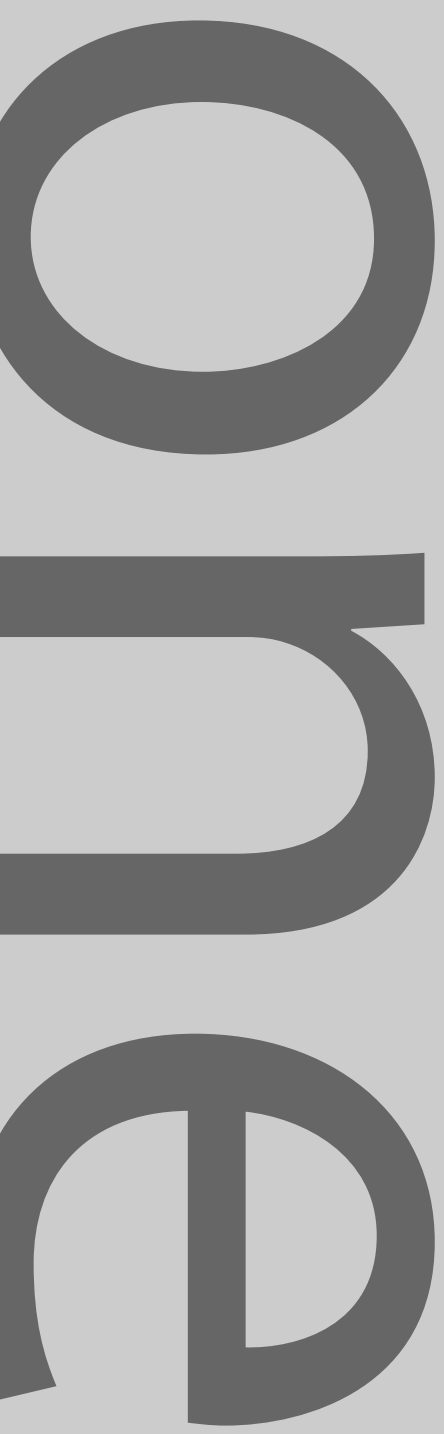


\section{Chapter one}

\section{Introduction}

Due to urbanization, industrialization and population growth, the demand for water is evident so is the associated increase in freshwater pollution resulting from discharging of untreated wastewater into freshwater bodies. Meeting the water demand and wastewater management requirements has also become increasingly difficult. Although there is supposed to be enough water resources to support the functions of water, however, this assertion is defeated due to uneven distribution of this resource in both time and space. An increase in water scarcity is progressively being observed as a universal risk since nearly 4.8 billion of the world's population live in areas where there is some form of water scarcity threat (Bakker, 2012; Vorosmarty et al., 2010). It has been estimated that approximately 1.6 billion people representing approximately a fourth of the human population are already facing acute water shortages and this is expected to double in the next decade (Roson \& Damania, 2017).

Many parts of the world are hit by acute water shortage, over exploitation leading to gradual destruction of these water resources and high levels of freshwater pollution resulting from anthropogenic factors (UNESCO, 2009; Vorosmarty, Douglas, Green, \& Revenga, 2005). It has also been estimated that over 300 million people in Africa reside in water scarce environments and rely on close to $70 \%$ of their scarce water resources for agricultural irrigation (NEPAD, 2006; Brown, 2006). It has been established that many developing countries are faced with direct disposal of untreated sewage into freshwater resources (Vigneswaran \& Sundaravadivel, 2004). These conditions have raised awareness of the state of water quality and the quantity of the water supplies within these regions. The challenges posed by water pollution has received a lot of attention and was a heavily debated subject in the United Nations conference on Environment and Development popularly known as the Earth Summit of Rio de Janeiro (UN, 1992). At this conference, it was decided that freshwater resources should be protected from contaminations in order to achieve global environmentally sustainable development. Again, this was revisited in the 2017 world water day which was dedicated to wastewater management as a means of protecting water resources (WHO, 2019). A very critical question to ask is will the available water resources be able to meet the ever-increasing demands across the globe? Where will the extra water that is required to sustain activities come from? Goal 6 of the sustainable development goals is to ensure availability and sustainable management of water and sanitation for all (UNDP, 2017). Part of the approach to achieving this is to reuse wastewater and this is where a cursory look at greywater recycling worth considering. Greywater is defined as wastewater without any contributions from toilet water (Casanova, Gerba, \& Karpiscak, 2001; Ledin, Eriksson, \& Henze, 2001; Ottoson \& Stenstrom, 2003). This water contains a maximum of up to 95 percent water with only 5 percent being solid wastes (Tchobanoglous, Burton, \& Stensel, 2002). Recycling and reusing of greywater that is being generated due to urbanization, population growth and industrialization can be a critical area that can be exploited in order to reduce the burden on the already stressed available freshwater resources.

Recycling greywater can help augment the already scarce water resources by providing alternative water sources for other uses. It plays a very key role by reducing the level of contamination to other freshwater 
resources. The excessive costs incurred in treating water for potable use is also reduced due to the reduction in demand for potable water. Reuse therefore can be a supplementary source to existing water sources in areas where there is acute water crisis or in arid climatic regions. Greywater contains nutrients which can promote plant growth when used for irrigation. While the nutrients in wastewater can promote plant growth when reused for irrigation, their disposal, in extreme cases, is detrimental to ecosystems of the receiving environment. In addition, there may be concerns about the levels of other toxic pollutants in wastewater.

The major concerns with greywater reuse has been issues with public health perceptions and appropriate technology for the reuse option (Vigneswaran \& Sundaravadivel, 2004). Recycled wastewater can be used to meet different water - demanding activities. The reuse option basically depends on the physical and biochemical characteristics of the wastewater. Greywater can be reused for potable or non-potable purposes because it can be used directly or treated to meet the appropriate reuse option. Among some of the non - potable uses are, agriculture, aquaculture, flushing toilets, car washing and other equally non - potable water uses. Potable reuse options require stringent treatment protocols.

\section{Problem statement}

Growth in water demand and increasing water pollution has led to acute water shortages in many parts of Africa and other developing countries. The resultant effect of this condition leads to inadequate access to sanitation and other related water use activities. The stop-gap measure has always been the provision other alternative sources of water such as development of groundwater resources, rainwater harvesting and water vending. However, all these sources are prone to some level of uncertainty in supply and availability. The current approach and existing modes of solving this and improving sanitation are not expected to lead to any major breakthrough in the near future. Many developed countries in arid and semi-arid areas have practiced greywater reuse to augment water supplies and this has been in existence for many years as part of the integrated water resource management (IWRM). Not only does this concept augment their water resources, but it also reduces the cost incurred in paying for water services. As this practice is worth adopting, developing countries and in particular sub-Saharan Africa has not yet embraced this concept of greywater reuse. People living within such water stressed communities have to walk for long distances in search of water which is used only once for a particular activity. Also, due to the non-existence of sewer systems in many developing countries, greywater generated in many households are left to join other freshwater bodies without being treated. These water bodies serve as point sources for some communities downstream and also source of water for livestock. Discharge of untreated greywater into the environment can lead to deterioration of freshwater resources due to the presence of many contaminants in greywater. However, this resource can be harnessed and reused in order to augment water supplies at the household levels. Due to the various cultural, religious and societal norms associated with many developing countries, this concept is seen as foreign and, in some instances, it may be regarded as a taboo to use 'spent water' for other water needs. Evidently, there is a need for a new approach to greywater management especially in developing countries. This thesis explores this practice of greywater reuse within a developing country by using a two-pronged approach. The first approach involved experimenting how to reduce a major contaminant from greywater using locally available agricultural waste material. The second approach involved using a socio-cognitive model to explore the 
main reasons why people will be willing to adopt this practice or otherwise taking into consideration cultural, religious and societal dynamics that exists in many developing countries within sub-Saharan Africa. Research around greywater reuse has largely focused on what exists in developed countries. However, studies that explore the dynamics of greywater reuse in a developing country viz the cultural, social, religious and appropriate technology are limited. This study has been designed to inform stakeholders on how to initiate or promote this concept in a developing country. Understanding and promoting greywater reuse can support the attainment of other sustainable development goals. Irrigation with greywater can help attain food security and improve nutrition which is the focus of goal 2 on ending hunger. Reducing water born-borne and other water related diseases as well as reducing the number of illness associated with soil and water pollution which is the focus of goal 3 on ensuring healthy lives (UNDP, 2015) .

\section{Research goal}

The main aim of the research was to explore greywater reuse at the household level in the study area taking into consideration the technical and non-technical approaches.

\section{Specific objectives}

1. To explore existing literature on greywater quality, reuse, perception and treatment systems.

2. To study the environmental impact associated with discharging untreated greywater into the environment within the study area.

3. To explore the potential of two agricultural waste materials on $\mathrm{BOD}_{5}$ and $\mathrm{COD}$ removal in greywater under batch conditions.

4. To study the $\mathrm{BOD}_{5}$ and $\mathrm{COD}$ removal using the best performing agricultural waste under continuous condition.

5. To identify the preferred reuse application of greywater using a socio-cognitive model known as the theory of planned behaviour.

6. To assess the willingness of households to adopt a greywater treatment and reuse system using an extended theory of planned behaviour model to include personal norms.

\section{Research questions}

To be able to explore and promote the option of greywater reuse, the following questions will have to be addressed:

i. What are the existing knowledge and gaps in greywater treatment and reuse?

ii. What are the pollutants of importance in regulatory discharge of greywater into the environment?

iii. What is the current greywater quality and generation rates within the study area?

iv. Which of the proposed materials have the optimum capacity for removing the important pollutants in the research?

v. What is the effect of process parameters in the treatment process?

vi. What are the factors that will determine the choice of reuse option with respect to societal, religious, educational factors? 
vii. What are the factors that will influence willingness of households to adopt a low-cost greywater reuse system?

\section{Outline of the thesis}

This thesis has been divided into eight chapters. Chapter 1 (current chapter) gives a brief background to the study including the problem being investigated, the objectives to be addressed and the relevance of this study to water resources.

Chapter two is a comprehensive review on the topic of greywater reuse and reviews literature on greywater characteristics, treatment systems and user perception.

Chapter three presents the quality and quantity assessment of greywater within the study area and the parameters of importance were identified to be BOD and COD.

Chapter four presents an exploration of activated carbon prepared from tropical almond shell and palm kernel shell in batch adsorption of BOD and COD. The capacity and kinetics of these materials were investigated using adsorption and kinetic models. The best performing material in this study was palm kernel shell and this was used in the next stage of the study.

Chapter four presents the performance of a fixed-bed column packed with activated carbon prepared from palm kernel shells for reducing BOD and COD in greywater. the data is evaluated using column models such as the Yoon Nelson, Thomas, BDST and Adams-Bohart.

Chapter six presents the use of socio-cognitive model known as the theory of planned behaviour (TPB) to predict the most preferred greywater reuse option that will be most appealing to users taking into consideration the cultural, social, religious, educational and gender perspectives.

Chapter seven explores the willingness of households to adopt or initiate greywater treatment and reuse systems at home using an extended model of the theory of planned behaviour with personal norm.

Chapter eight presents a general overview of the results of the study and lessons learnt and provides recommendations for future research and strategies for implementation. 

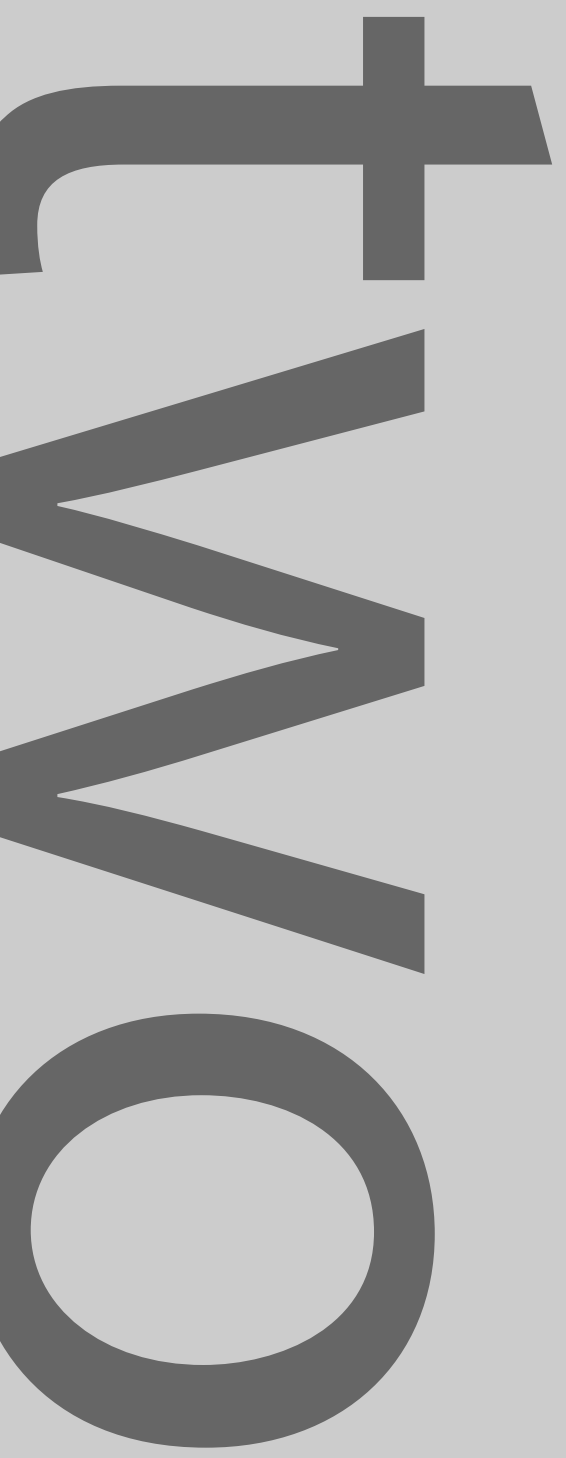


\section{Chapter two}

\section{Published as:}

Oteng-Peprah, M., Acheampong, M. A., \& de Vries, N. K. (2018). Greywater Characteristics, Treatment Systems, Reuse Strategies and User Perception-a Review. Water, Air, \& Soil Pollution, 229(8), 255. doi:10.1007/s11270-018-3909-8 


\begin{abstract}
This paper presents a literature review of the quality of greywater generated in different, especially developing, countries, constituents found in greywater, some treatment systems, natural materials for treatment, some reuse strategies and public perception regarding greywater reuse. The review shows that generation rates are mostly influenced by lifestyle, types of fixtures used and climatic conditions. Contaminants found in greywater are largely associated with the type of detergent used and influenced by other household practices. Many of the treatment systems reviewed were unable to provide total treatment as each system has its unique strength in removing a group of targeted pollutants. The review revealed that some naturally occurring materials such as moringa oliefera, saw dust, can be used to remove targeted pollutants in greywater. The study further showed that user perceptions towards greywater treatment and reuse were only favorable towards non-potable purposes, mostly due to perceived contamination or lack of trust in the level of treatment offered by the treatment system.
\end{abstract}

\title{
Keywords
}

Greywater, Reuse, Natural media, treatment systems, user perception. 


\section{Introduction}

The total volume of freshwater on earth far outweighs the human demands. Out of the overall water resources on earth, about $97 \%$ can be found in the oceans while the remaining $3 \%$ remains available for direct exploitation, however, out of this $3 \%$, the quantity of water that is available for use by humans is estimated at one-hundredth (Eakin \& Sharman, 2010; Gleick, 1993). Uneven distribution of water in both time and space sways the use of water to other geographical areas depriving others of this resource. Biological survival remains one of the key factors of water use with its associated use also for household needs and for food production and other developmental needs. Many parts of the world are hit by acute water shortage, over-exploitation of water resources leading to gradual destruction of these water resources and high levels of freshwater pollution resulting from anthropogenic factors. Currently, it has been estimated that about 800 million people live under a threshold of water stress and this number is expected to reach three billion in 2025 (Qureshi \& Hanjra, 2010; UNDP, 2017). Due to urbanization, industrialization and population growth, the demand for water is evident; however, will the available water resources meet the ever-growing needs in a sustainable manner? Where will the extra water that is required to sustain human activities come from? This question calls for interventions and strategies that will help address these concerns. This is where a cursory look at greywater reuse is worthwhile.

Greywater is defined as wastewater without any contributions from toilet water (Casanova et al., 2001; Ledin et al., 2001; Ottoson \& Stenstrom, 2003). It is considered high volume, low strength wastewater with high potential for reuse and application. The composition of greywater is varied and depends on the lifestyle, fixtures and climatic conditions (Abedin \& Rakib, 2013; do Couto, Calijuri, Assemany, Santiago, \& Carvalho, 2013; Katukiza, Ronteltap, Niwagaba, Kansiime, \& Lens, 2014). Reuse of greywater has been an old practice and it is still being done in areas that are water stressed. This practice if given the needed attention can help reduce the overreliance on freshwater resources and reduce the pollution caused by discharge of untreated greywater into freshwater resources. It can also be a supplementary source to existing water sources in areas where there is acute water crisis or in arid climatic regions. Recycled greywater can be used for different water - demanding activities including potable and non-potable uses such as toilet flushing and agriculture. The major concerns with greywater reuse have been issues with public health perceptions and inappropriate technology for the reuse option (Vigneswaran \& Sundaravadivel, 2004). Many researchers have studied characteristics of greywater with respect to fixtures, life style patterns and type of settlement (Alsulaili \& Hamoda, 2015; do Couto et al., 2013; Katukiza et al., 2014). However, the aim of this study is to assess the performance of greywater treatment system, to further review greywater reuse perceptions, to identify gaps of greywater systems with emphasis on developing countries and to identify scope for further research. This review used resources from peer reviewed journals, documents from the internet and text books. The methodological framework that guided this review is presented in figure 2.1. 

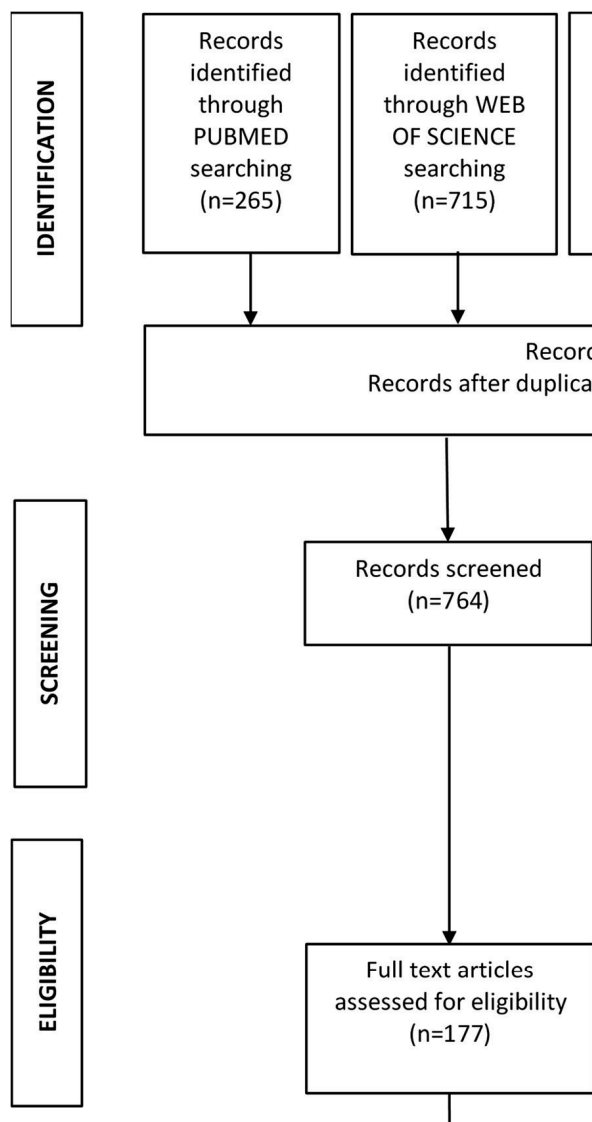
Technical briefs, Text books and dissertations $(n=9)$

\begin{tabular}{|c|} 
Records \\
identified \\
through \\
GOOGLE \\
SCHOLAR \\
searching \\
( $\mathrm{n}=979)$ \\
\hline
\end{tabular}

Documents and other resources identified through internet $(n=15)$

Records after duplicates removed $(n=1,983-1,219=764)$

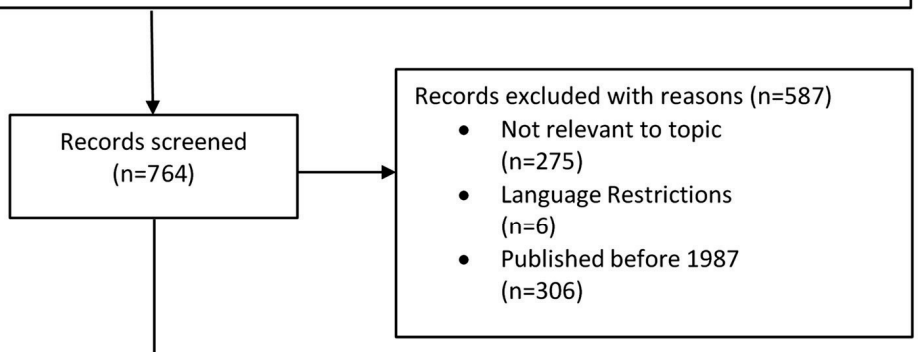

름

Figure 2. 1 Methodological framework

\section{Greywater quantity}

Greywater reuse has been considered as a reliable method of ensuring water security as compared to other methods of water capture such as rainwater harvesting which is dependent on hydrological conditions. The amount of greywater produced in a household can vary greatly ranging from as low as $15 \mathrm{~L}$ per person per 
day for poor areas to several hundred per person per day. Factors that account for such huge disparities are mostly attributed to geographical location, lifestyle, climatic conditions, type of infrastructure, culture, habits among others. Greywater accounts for up to $75 \%$ of the wastewater volume produced by households and this can increase to about $90 \%$ if dry toilets are used (Hernandez Leal, Temmink, Zeeman, \& Buisman, 2010). It has also been estimated that greywater produced accounts for about $69 \%$ of domestic water consumption (A. Jamrah, Al Omari, Al Qasem, \& Abdel Ghani, 2011). Table 2.1 presents different greywater generation rates in some reported studies in different countries.

Table 2. 1 Greywater generation rates in different studies

\begin{tabular}{lll}
\hline Location & $\begin{array}{l}\text { Generation } \\
\left(\mathrm{LC}^{-1} \mathrm{~d}^{-1}\right)\end{array}$ & Reference \\
\hline Africa and Middle East & $14-161$ & $\begin{array}{l}\text { (Al-Hamaiedeh \& Bino, 2010; Halalsheh et al., 2008; Morel \& } \\
\text { Diener, 2006) } \\
\text { (Morel \& Diener, 2006) }\end{array}$ \\
Asia & $72-225$ & $\begin{array}{l}\text { (Adendorff \& Stimie, 2005) } \\
\text { Guateng, South-Africa }\end{array}$ \\
$\begin{array}{l}\text { (Faraqui \& Al-Jayyousi, 2002) } \\
\text { Jordan }\end{array}$ & 50 & (M. C. Alderlieste \& J. G. Langeveld, 2005) \\
Mali & 30 & (A. Jamrah, Al-Futaisi, Prathapar, \& Harrasi, 2008) \\
Muscat, Oman & 151 & (Shresta, 1999) \\
Nepal & 72 & (Ottoson \& Stenstrom, 2003) \\
Stockholm & 65 & (Casanova et al., 2001) \\
Tucson Arizona, USA & 123 & (Busser, Pham, Morel, \& Nguyen, 2006) \\
Vietnam & $80-110$ &
\end{tabular}

\section{Greywater composition}

The composition of greywater varies and it is largely a reflection of the lifestyle and the type and choice of chemicals used for laundry, cleaning and bathing. The quality of the water supply and the type of distribution network also affects the characteristics of greywater. There will be significant variations in the composition of greywater in both place and time which may be due to variations in water usage in relation to the discharged quantity. The composition may also be affected by chemical and biological degradation of some compounds within the transportation and storage network. Generally, greywater contains high concentrations of easily biodegradable organic materials and some basic constituents which are largely generated from households. These include nutrients such as nitrates and all its derivatives, phosphorus and its derivatives, but others include xenobiotic organic compounds (XOC's) (Fatta-Kassinos, Kalavrouziotis, Koukoulakis, \& Vasquez, 2011), biological microbes such as faecal coliforms, salmonella, and general hydrochemical constituents. Recent studies have however found pharmaceuticals, health and beauty products, aerosols, pigments, (Eriksson, Auffarth, Eilersen, Henze, \& Ledin, 2003) and toxic heavy metals such as $\mathrm{Pb}, \mathrm{Ni} \mathrm{Cd}, \mathrm{Cu}, \mathrm{Hg}, \mathrm{Cr}$, (Aonghusa \& Gray, 2002; Eriksson, Srigirisetty, \& Eilersen, 2010) in appreciable concentrations in greywater. The presence of these contaminants in greywater is an indication of the gradual increase in the level of complexity in the composition of greywater.

\section{Physical constituents}

These are constituents that are associated with the physical appearance of greywater and include, temperature, turbidity, electrical conductivity, suspended solids, among others. Greywater normally has temperature range of between $18-35^{\circ} \mathrm{C}$ and the rather high temperature may be originating from warm water used for personal hygiene and cooking activities. These high temperatures may favour microbiological growth which is undesirable and may also cause precipitation of certain carbonates such as $\mathrm{CaCO}_{3}$ and other inorganic salts which become less soluble at high temperatures. The concentration of total suspended solids 
in greywater can range within 190-537mg/L as has been reported (Edwin, Gopalsamy, \& Muthu, 2014; M. Oteng-Peprah, de Vries, \& Acheampong, 2018). Greywater with much of the water originating from the kitchen and laundry accounts for the relatively high values of TSS and this may be due to washing of clothes, shoes, vegetables, fruits, tubers and many others which may contain sand, clay and other materials that could increase TSS. The ranges recorded for electrical conductivity in greywater is between $14-3000 \mu \mathrm{Scm}^{-1}$ (Ciabatti, Cesaro, Faralli, Fatarella, \& Tognotti, 2009; Prathapar et al., 2005). Groundwater sources and water scarce areas are mostly associated with high electrical conductivity due to dissolved materials. Poor or old plumbing materials also contribute to the increase in electrical conductivity due to leaching into greywater sources. The range of turbidity recorded for greywater is between 19 and 444NTU and it is mostly influenced by the water use activities. Greywater that has most of its sources originating from the kitchen and laundry is expected to become more turbid due to the presence of suspended matter.

\section{Chemical contaminants}

To identify the different chemical constituents in greywater, it is important to understand the sources of contaminants. Significant chemical constituents in greywater are from chemicals used for cleaning, cooking and bathing purposes. The $\mathrm{pH}$ in greywater to a large extent depends on the $\mathrm{pH}$ and alkalinity in the water supply and normally is within the range of 5-9. Greywater with most of its sources originating from the laundry will generally exhibit high $\mathrm{pH}$ due to the presence of alkaline materials used in detergents. The major chemical constituents found in greywater which is generated as a result of cleaning or washing activities are surfactant. These surfactants serve as the main active agent in most cleaning products. They can be either cationic or anionic in nature with a majority of cleaning and laundry products being anionic (Jakobi \& Lohr, 1987). Cationic surfactants are generally salt based and they constitute a source of ammonium in the greywater. Other constituents found in greywater also include nitrates and phosphate which are reportedly from ammonium and, cationic surfactants and laundry disinfectants respectively (Eriksson, Auffarth, Henze, \& Ledin, 2002). Other constituents such as sodium which is also from cooking and preservation activities in the kitchen can also be found in appreciable levels. Sodium based soaps also contribute significant quantity of sodium into greywater. Other additives such as builders control water hardness in detergents and also serve as the main source of phosphate contaminant in greywater (Lange, 1994). Nutrients such as $\mathrm{N}$ and $\mathrm{P}$ are associated with kitchen and laundry activities. Greywater sources with high nutrients concentrations are mostly made up of a high fraction of kitchen and laundry sources (Boyjoo, Pareek, \& Ang, 2013). Kitchen waste are the primary source of nitrogen in greywater and range between $4-74 \mathrm{mg} / \mathrm{L}$ while washing detergents are the primary source of phosphates found in grey water which also range between $4-14 \mathrm{mg} / \mathrm{L}$ (Boyjoo et al., 2013).

The conventional wastewater parameters such as biochemical oxygen demand $\left(\mathrm{BOD}_{5}\right)$ and chemical oxygen demand $(C O D)$ always show a dominance of $C O D$ over $\mathrm{BOD}_{5}$. The biodegradability of greywater is determined by the $\mathrm{BOD}_{5} / \mathrm{COD}$ ratios. The ratio determines the ease with which bacteria can decompose the organic matter in the greywater. Mostly, all types of greywater show good biodegradability in terms of the $\mathrm{BOD}_{5} / \mathrm{COD}$ ratios (Li, Wichmann, \& Otterpohl, 2009). The average $\mathrm{BOD}_{5} / \mathrm{COD}$ ratios in greywater have ranged between 0.31-0.71 which is an indication that almost half of the organic matter in greywater is biodegradable (Halalsheh et al., 2008). However, other studies have recorded ratios as high as 4:1 (Boyjoo et al., 2013). The dominance of $C O D$ to $\mathrm{BOD}_{5}$ has largely been due to the presence of XOC's that increases COD. XOC's are synthetic organic compounds that are present in household chemicals and pharmaceuticals such as bleaches, surfactants, softeners and builders and beauty products. XOC's can also be formed by partial modification of chemicals in chemical or biological treatment of greywater (Fatta-Kassinos et al., 2011). XOC's are recalcitrant to conventional treatment protocols and can easily accumulate in plants and animals and subsequently pose risks to the natural environment (Fatta-Kassinos et al., 2011). It has been reported that about 900 potential 
XOC's have been identified in greywater solely based on the ingredients of different cosmetics and detergents in Denmark (Eriksson et al., 2002). A study identified the presence of antibiotics in greywater which may lead to proliferation of resistant bacteria strains (Le-Minh, Khan, Drewes, \& Stuetz, 2010). Another study (Revitt, Eriksson, \& Donner, 2011) also identified the presence of benzene and 4-nitrophenol in greywater in appreciable concentrations. Other hazardous substances such as brominated flame retardants, polycyclic aromatic hydrocarbons, monocyclic aromatics and triclosans, phthalates have been identified in greywater (Palmquist \& Hanaeus, 2005). Table 2.2 presents some selected physicochemical parameters of greywater with their concentrations in some selected high and low-income countries.

Table 2. 2 Physicochemical characteristic of Greywater sin low and high-income countries

\begin{tabular}{|c|c|c|c|c|c|c|c|c|}
\hline \multirow[t]{2}{*}{ Parameter } & \multicolumn{4}{|c|}{ Low income countries } & \multicolumn{4}{|c|}{ High income countries } \\
\hline & India ${ }^{a}$ & Pakistan $^{\text {b }}$ & Niger $^{c}$ & Yemen $^{d}$ & USA $^{\mathrm{e}}$ & $U^{f}$ & Spaing & Germany $^{h}$ \\
\hline $\mathrm{pH}$ & $7.3-8.1$ & 6.2 & 6.9 & 6 & 6.4 & $6.6-7.6$ & 7.6 & 7.6 \\
\hline Turbidity NTU & - & - & 85 & 619 & 31.1 & $26.5-164$ & 20 & 29 \\
\hline $\mathrm{EC} \mu \mathrm{S} / \mathrm{m}$ & - & - & - & - & 23 & 32.7 & - & 64.5 \\
\hline TSS mg/L & $100-283$ & 155 & - & 511 & 17 & $37-153$ & 32 & - \\
\hline TDS mg/L & 573 & 102 & - & - & 171 & - & - & - \\
\hline $\mathrm{BOD}_{5} \mathrm{mg} / \mathrm{L}$ & $100-188$ & 56 & 106 & 518 & 86 & $39-155$ & - & 59 \\
\hline COD mg/L & $250-375$ & 146 & - & 2000 & - & $96-587$ & $151-177$ & 109 \\
\hline $\mathrm{Cl} \mathrm{mg/L}$ & 53 & - & - & - & - & - & - & - \\
\hline Oil \& Grease mg/L & 7 & - & - & - & - & - & - & - \\
\hline Nitrate $\mathrm{mg} / \mathrm{L}$ & 0.67 & - & - & 98 & - & 3.9 & - & - \\
\hline T. Nitrate $\mathrm{mg} / \mathrm{L}$ & - & - & - & - & 13.5 & 4.6-10.4 & $10-11$ & 15.2 \\
\hline T. Phosp mg/L & 0.012 & - & - & - & 4 & $0.4-0.9$ & - & 1.6 \\
\hline $\mathrm{FC}(\mathrm{CFU})$ & - & - & - & 1.9 & - & - & - & $1.4 \times 10^{5}$ \\
\hline E. Coli (CFU) & - & - & - & - & $5.4 \times 10^{5}$ & $10-3.9 \times 10^{5}$ & - & - \\
\hline Ca mg/L & 0.13 & - & - & - & - & - & - & - \\
\hline $\mathrm{Mg} \mathrm{mg/L}$ & 0.11 & - & - & - & - & - & - & - \\
\hline $\mathrm{Na} \mathrm{mg/L}$ & $32-50$ & - & - & - & - & - & - & - \\
\hline
\end{tabular}

a(Parjane \& Sane, 2011)

b(Pathan, Mahar, \& Ansari, 2011)

'(Hu et al., 2011)

d(Al-Mughalles, Rahman, F.B., Mahmud, \& Jahil, 2012)

e(Jokerst, Sharvelle, Hollowed, \& Roesner, 2011)

f(Birks \& Hills, 2007; Pidou et al., 2008)

g(March \& Gual, 2007; March, Gual, \& Simonet, 2004)

${ }^{h}$ (Merz, Scheumann, El Hamouri, \& Kraume, 2007)

\section{Biological Characteristics}

Greywater contains microorganisms such as bacteria, protozoa and helminths which are introduced into it by body contact. Inappropriate food handling in the kitchen and direct handling of contaminated food have been identified as sources of enteric pathogenic bacteria such as Salmonella and Campylobacter into greywater (Maimon, Friedler, \& Gross, 2014; Ottoson \& Stenstrom, 2003). Fecal contamination is also common in greywater and is largely associated with poor personal hygiene and disposal of greywater which contains washed nappies. Pathogenic E. coli and enteric viruses have been detected in greywater with majority of the water originating from laundry sources during a microbial monitoring programme in Melbourne Australia (O'Toole et al., 2012). In this study, $18 \%$ of samples contained enteric viruses, $7 \%$ 
enterovirus and $11 \%$ of $\mathrm{E}$. coli. The most common indicators used to assess fecal contamination are coliform bacteria and E. coli. Studies conducted by (Eriksson et al., 2002; Ottoson \& Stenstrom, 2003) revealed a large collection of excreta-related pathogens associated with greywater. Other studies have further identified a number of pathogens in greywater and these are Pseudomonas (Benami, Gillor, \& Gross, 2015a; Khalaphallah \& Andres, 2012), Legionella (Birks, Colbourne, Hills, \& Hobson, 2004), Giardia (Birks et al., 2004; Birks \& Hills, 2007), Cryptosporidium (Birks et al., 2004), and Staphylococcus Aureus (Benami et al., 2015a; Kim et al., 2009; Maimon et al., 2014; Shoults \& Ashbolt, 2017) in greywater. Table 2.3 presents some selected biological parameters with their concentrations as reported in other studies.

Table 2. 3 Biological characteristic of Greywater s in low and high-income countries

\begin{tabular}{|c|c|c|}
\hline Name of microbe & Concentration & Source \\
\hline Total coliforms Counts $/ 100 \mathrm{~mL}$ & $1.2 \times 10^{3}-8.2 \times 10^{8}$ & $\begin{array}{l}\text { (Alsulaili, Hamoda, Al-Jarallah, \& Alrukaibi, 2017; } \\
\text { Dwumfour-Asare, Adantey, Nyarko, \& Appiah-Effah, } \\
\text { 2017; Mandal et al., 2011; Masi et al., 2010; M. } \\
\text { Oteng-Peprah et al., 2018) }\end{array}$ \\
\hline E. coli & Up to $6.5 \times 10^{6}$ & $\begin{array}{l}\text { (Atanasova et al., 2017; Friedler, Kovalio, \& Ben-Zvi, } \\
\text { 2006; Khalaphallah \& Andres, 2012; Kim et al., 2009; } \\
\text { M. Oteng-Peprah et al., 2018; Paulo, Begosso, } \\
\text { Pansonato, Shrestha, \& Boncz, 2009) }\end{array}$ \\
\hline Fecal coliforms & Up to $1 \times 10^{6}$ & $\begin{array}{l}\text { (Halalsheh et al., 2008; Mandal et al., 2011; Masi et } \\
\text { al., 2010) }\end{array}$ \\
\hline Pseudomonas aeruginosa & $1.4 \times 10^{4}$ & (Benami et al., 2015a; Khalaphallah \& Andres, 2012) \\
\hline Staphylococcus aureus & $1.2 \times 10^{2}-1.8 \times 10^{3}$ & $\begin{array}{l}\text { (Benami, Gillor, \& Gross, 2015b; Kim et al., 2009; } \\
\text { Maimon et al., 2014; Shoults \& Ashbolt, 2017) }\end{array}$ \\
\hline Salmonella typhi & $5.4 \times 10^{3}$ & (Kim et al., 2009) \\
\hline Salmonella spp & $3.1 \times 10^{3}$ & (M. Oteng-Peprah et al., 2018) \\
\hline
\end{tabular}

\section{Treatment systems}

Management of greywater graduates from simple to extremely complex when the necessary strategies and technology is not in place or not properly implemented. Many developed countries have however implemented from simple to advanced methods of handling, managing and treating greywater with some countries recycling the greywater for both potable and non-potable uses. Treatment systems have been used to reduce the level of contamination in greywater before reuse or final disposal. They are contaminantspecific and each is applied along the conventional wastewater treatment sequence (pre-treatment, primary, secondary and tertiary treatment). Each of these systems adopt either a physicochemical or biological means of treatment. Physicochemical methods adopt physical and/or chemical methods of treatment including filtration, adsorption, reverse osmosis, among others. Biological treatment methods adopt a combination of microbes, sunlight and oxygen manipulation; examples of such systems include activated sludge systems, trickling filters, waste stabilization ponds, rotating biological contactors and many others. The widely used systems have mostly been filtration, rotating biological contactors, membrane bioreactors, constructed wetlands and upflow anaerobic sludge blankets (UASB). These systems have found their application in addressing the emerging greywater pollution experienced in most developing countries. This review therefore discusses the performance of these systems.

\section{Filtration}

Filtration involves removal of particulate matter which is not removed by preceding processes. In filtration systems, both physical and biological processes remove solids, however, this review considers only physical 
removal of solids because that is the method adopted in most greywater treatment schemes. Filtration media could be in the form of sand, gravel, fine mesh and many others. Gross, Shmueli, Ronen, and Raveh (2007) studied the performance of a filtration system in greywater treatment using pebbles of $2 \mathrm{~cm}$ thick placed over drain holes and followed by a $12 \mathrm{~cm}$ middle layer consisting of $12 \mathrm{~cm}$ of plastic filter media and finally topped by $4 \mathrm{~cm}$ thick layer of peat. Dalahmeh et al. (2012) also studied the performance of a filtration system using pine bark, activated charcoal, polyurethane foam and sand as filter media in treating greywater. The performance of a coarse filtration system followed by slow sand filtration with a hydraulic retention time of $8 \mathrm{hr}$ and $24 \mathrm{hrs}$ respectively was studied by Finley, Barrington, and Lyew (2009). Parjane and Sane (2011) used coconut shell, coarse saw dust, charcoal, bricks and sand as filter materials to assess the performance of greywater treatment. A four-barrel filtration unit has been used to investigate greywater treatment by AlHamaiedeh and Bino (2010). These barrels were arranged in series and the first three were loaded with gravels of $2-3 \mathrm{~cm}$ diameter. The final barrel was used to collect the treated effluent for irrigation. Gross (2008) adopted a hybrid filtration system utilizing a $130 \mu \mathrm{m}$ net filtration, a tuff filter, a sand filter and followed by electrolysis in Israel. Zuma, R, Whittington-Jones, and Burgess (2009) used a mulch tower system to treat greywater in south Africa. This was constructed by using mulch, coarse sand, fine and coarse gravel. This was contained in a $650 \mathrm{~mm}$ high plastic column of $150 \mathrm{~mm}$ diameter with a stainless-steel sieve mesh placed on top to remove big particles. From the reviewed filtration systems, only bark filters were able to meet the $\mathrm{pH}$ criteria for reuse. More so, only the bark and charcoal filters could meet the $\mathrm{BOD}_{5}$ regulatory standard for reuse. Removal rates of total phosphorous was high in bark, charcoal and sand filters. The performance of filtration systems discussed is presented in table 2.4 .

\section{Constructed wetland}

Constructed wetland (CW) is an artificial wetland constructed utilizing ecological technology to mimic conditions that occur in a natural wetland. The technology adopts special flora and fauna, soil and microorganisms to remove pollutants of interest. They are normally classified under three main types namely subsurface flow, surface flow and floating treatment wetland. The subsurface flow systems have been the most widely used constructed wetlands and they come in two main technologies, vertical flow constructed wetland (RVFCW) and horizontal flow constructed wetland (HFCW). Each removes contaminants by a combination of physical, chemical and biological processes and the treatment efficiency depends on factors such as loading rate and the availability of electron acceptors (Halalsheh et al., 2008). They have high potential of removing $\mathrm{BOD}_{5}$, suspended solids, and some heavy metals such as $\mathrm{Pb}, \mathrm{Zn}$, Fe among others. The performance of a RVFCW was studied and it was observed that removal of ammonia nitrate was very low as compared to other systems (Gross et al., 2007; Travis, Wiel-Shafran, Weisbrod, Adar, \& Gross, 2010). Gross (2008) also investigated the performance of HFCW in greywater treatment and observed that the quality of effluent improved if there was a pretreatment of the greywater. In this study, the average retention time was about 30hrs and it was realized that electrical conductivity increased from 170 to $190 \mathrm{mS} / \mathrm{m}$, T-N was reduced from 31 to $23 \mathrm{mg} / \mathrm{L}$ and T-P was also reduced from 48 to $46 \mathrm{mg} / \mathrm{L}$ representing 25.8 and $4.2 \%$ respectively. One major advantage of $\mathrm{CW}$ is its ability to run on its own without the attention of an operator. However, its removal rates for $\mathrm{Na}, \mathrm{Ca}$ and $\mathrm{Mg}$ are relatively low and it also leads to increases in electrical conductivity (EC) which might be due to the dissolution of organic matter in the treated water leading to increase in the Total dissolved solids (TDS) and subsequently affecting the EC. They are also unable to remove some microbiological agents such as $E$. coli and helminth eggs and as such will require further treatment if the objective of the treatment is reuse. However, $\mathrm{CW}$ can produce effluents with $\mathrm{BOD}_{5}$ and TSS meeting the regulatory limits. The removal efficiencies of these discussed CW are presented in table 2.4. 


\section{Rotating Biological Contactors}

Rotating biological contactors (RBCs) are fixed bed reactors consisting of rotating disks and mounted on a horizontal shaft. They are partially submerged and rotated as wastewater flows through. The microbes that do the treatment are alternatively exposed to the atmosphere allowing both aeration and assimilation of dissolved organic pollutants and nutrients for degradation. Pathan et al. (2011) studied the performance of a single-stage RBC on greywater in Pakistan. The RBC was made of plastic sheets and the disks from textured plastic. The greywater was kept in the system for a specified period of time while the rotating discs were submerged up to $40 \%$ in the greywater. Friedler, Yardeni, Gilboa, and Alfiya (2011) studied the potential of RBC to remove indicator bacteria (Faecal Coliforms, Heterotrophic bacteria) and specific pathogens (Pseudomonas aeruginosa sp., Staphylococcus aureus sp.). The study concluded that RBC removed 88.599.9\% of all four bacteria groups. Gilboa and Friedler (2008) studied the performance of RBC on removal of faecal coliforms (FC), Staphylococcus Aureus sp., Pseudomonas aeruginosa sp. and Clostridium perfringes sp in greywater using RBC followed by sedimentation. The study concluded that the system removed up to $99 \%$ of all these microorganisms which were in the greywater. RBC systems perform well with respect to $\mathrm{pH}$, $\mathrm{BOD}_{5}, \mathrm{COD}$, reduced microbial loads and produced effluents that meet discharge guidelines. Performance of the system is presented in table 2.4 .

\section{Sequencing Batch Reactor}

A sequencing batch reactor (SBR) is a type of activated sludge process used for wastewater treatment. All the treatment process takes place in batches in the reactor tank. The batch is sequenced through a series of treatment stages and performs equalization, biological treatment and secondary clarification in a single tank using a time-controlled sequence. Lamine, Bousselmi, and Ghrabi (2007) conducted a study on greywater treatment using SBR in a student house. This study assessed the performance of treatment by varying the hydraulic retention times (HRTs) and it revealed an effect on nitrification with the varying HRT. A similar study by (Scheumann \& Kraume, 2009) also used a pilot scale SBR by varying the retention time and observed the removal of $\mathrm{COD}, \mathrm{NH}_{4}-\mathrm{N}$, and $\mathrm{TN}$ was sufficient to meet discharge reuse guidelines, however, there was nitrification in this study as also reported by (Lamine et al., 2007). In this study, feed stock concentration of COD $250 \mathrm{mg} / \mathrm{L}, \mathrm{NH} 4-\mathrm{N} 11.9 \mathrm{mg} / \mathrm{L}$ and TN $=17.1$ were reduced to $18.9 \mathrm{mg} / \mathrm{L}, 4.1 \mathrm{mg} / \mathrm{L}$ and $0.37 \mathrm{mg} / \mathrm{L}$ respectively all being below the mandatory values for reuse applications. Krishnan, Ahmad, and Jeru (2008) investigated the performance of greywater treatment from residential houses in Malaysia on a square bottom SBR at fixed HRT. An SBR has also been used in a demonstration project in the Netherlands to treat greywater from 32 houses (Hernandez Leal et al., 2010). SBRs have removal efficiencies of up to $98 \%$ for $\mathrm{BOD}_{5}$ and COD, up to $80 \%$ TN and up to $99 \%$ for $\mathrm{NH}_{4}-\mathrm{N}$. The HRT has been found to be a limiting factor in the performance of SBRs since difference HRTs result in different effluent qualities as is shown in the different studies (Lamine et al., 2007; Scheumann \& Kraume, 2009). The performance of this system has been presented in table 2.4.

\section{Membrane Bioreactor}

A membrane bioreactor (MBR) is a perm-selective process integrated with a biological process for treating greywater. It works on a combination of biological, microfiltration and ultrafiltration systems to achieve treatment. It is an appropriate solution that can be used for greywater treatment and reuse in densely urbanized areas where space has high value, due to its compact size. Atanasova et al. (2017) studied the performance of an MBR on greywater treatment in a hotel in Spain. The removal efficiency for COD ranged from 80 to $95 \%$, where COD concentration in the effluent was below the quantification limit $30 \mathrm{mg} / \mathrm{L}$ based on the Spanish legislation for water reuse. Ammonia and TN removal were on average at high level $80.5 \%$ and $85.1 \%$ respectively. The treatment performance of an MBR made up of an ultrafitration membrane was also studied by Merz et al. (2007) on greywater from a sports complex in Morocco. Huelgas and Funamizu (2010) studied the treatment of greywater using a laboratory scale MBR under varying pressure. Jong et al. 
(2010) also used anaerobic-anoxic-oxic MBR to treat greywater in Korea with micro filter of pore size $0.45 \mu \mathrm{m}$. These systems could achieve very good effluent which meets regulatory standards for reuse. A nominal pore size of $0.1 \mu \mathrm{m}$ has been found to remove fecal coliforms. Performance of this system is presented in table 2.4 .

\section{Upflow Anaerobic Sludge Blanket}

The Upflow anaerobic sludge blanket (UASB) has remained one of the most widely used wastewater treatment system for various types of wastewater streams. It works on an anaerobic process and retains a high concentration of active suspended biomass and produces better settleable sludge than other treatment systems. Greywater from 32 houses in the Netherlands were treated using this system (Hernandez Leal et al., 2010). Elmitwalli, Shalabi, Wendland, and Otterpohl (2007) also used this system to study the treatment of greywater in Lubeck Germany by varying the retention time. Abdel-Shafy, Al-Sulaiman, and Mansour (2015) investigated the efficiency of UASB in greywater treatment for unrestricted use in Egypt. The raw greywater characteristics with average concentrations of $95,392,298,10.45,0.4,118.5$ and 28mg/L for TSS, $\mathrm{COD}, \mathrm{BOD}_{5}, \mathrm{TP}$, Nitrates, oil and grease, and TKN respectively was treated in a UASB. After treatment, the effluents concentration was 76.65, 165.496 .85 and $19.31 \mathrm{mg} / \mathrm{L}$ for TSS, COD, BOD ${ }_{5}$ and oil and grease respectively. This represents removal efficiencies of $19.3 \%$ for TSS, $57.8 \%$ for COD, $67.5 \%$ for $\mathrm{BOD}_{5}$ and $83 \%$ for oil and grease. UASB's perform better when they are integrated with other systems. The performance of the system is presented in table 2.4 .

Table 2. 4 Treatment efficiencies of some selected greywater treatment systems

\begin{tabular}{|c|c|c|c|c|c|c|}
\hline Parameter & Filtration $^{a}$ & Wetlands ${ }^{b}$ & $\mathrm{SBR}^{\mathrm{C}}$ & $\mathrm{RBC}^{\mathrm{d}}$ & $\mathrm{MBR}^{\mathrm{e}}$ & UASB $^{f}$ \\
\hline Turbidity NTU & - & - & - & - & $98-99 \%$ & - \\
\hline $\mathrm{EC} \mathrm{uS} / \mathrm{m}$ & - & - & - & - & - & - \\
\hline TSS mg/L & $53-93 \%$ & $90-98 \%$ & - & $9-12 \%$ & Up to $100 \%$ & - \\
\hline TDS mg/L & - & - & - & - & - & - \\
\hline $\mathrm{BOD}_{5} \mathrm{mg} / \mathrm{L}$ & $89-98 \%$ & up to $99 \%$ & $90-98 \%$ & $27-53 \%$ & $93-97 \%$ & Up to $67 \%$ \\
\hline COD mg/L & $37-94 \%$ & $81-82 \%$ & $90-98 \%$ & $21-61 \%$ & $86-99 \%$ & $38-79 \%$ \\
\hline $\mathrm{Cl} \mathrm{mg} / \mathrm{L}$ & - & $92-94 \%$ & - & - & - & - \\
\hline Oil \& Grease mg/L & Up to $97 \%$ & Up to 95.45 & - & - & - & $83.7 \%$ \\
\hline Nitrate $\mathrm{mg} / \mathrm{L}$ & $17-73 \%$ & - & - & - & $6-72 \%$ & - \\
\hline T. Nitrate $\mathrm{mg} / \mathrm{L}$ & $5-98 \%$ & $26-82$ & $80 \%$ & - & $52-63 \%$ & 24 to $58 \%$ \\
\hline T. Phosp mg/L & Up to $100 \%$ & Up to $71 \%$ & - & - & Up to $19 \%$ & 10 to $39 \%$ \\
\hline $\mathrm{FC}(\mathrm{CFU})$ & - & - & & $88.5-99.9 \%$ & Up to $99 \%$ & - \\
\hline E. Coli (CFU) & Up to $100 \%$ & - & & $88.5-99.9 \%$ & - & - \\
\hline Ca mg/L & Up to $100 \%$ & - & - & - & - & - \\
\hline $\mathrm{Mg} \mathrm{mg/L}$ & Up to $100 \%$ & - & - & - & - & - \\
\hline $\mathrm{Na} \mathrm{mg} / \mathrm{L}$ & $47 \%$ & - & - & - & - & - \\
\hline \multicolumn{7}{|c|}{$\begin{array}{l}\text { a (Al-Hamaiedeh \& Bino, 2010; Dalahmeh et al., 2012; Finley et al., 2009; Gross, 2008; Parjane \& Sane, } \\
\text { 2011; Zuma et al., 2009) }\end{array}$} \\
\hline \multicolumn{7}{|c|}{ b (Gross, 2008; Gross et al., 2007; Travis et al., 2010) } \\
\hline \multicolumn{7}{|c|}{ c (Hernandez Leal et al., 2010; Krishnan et al., 2008; Lamine et al., 2007; Scheumann \& Kraume, 2009) } \\
\hline \multicolumn{7}{|c|}{ d (Friedler et al., 2011; Gilboa \& Friedler, 2008; Pathan et al., 2011) } \\
\hline \multicolumn{7}{|c|}{ e (Atanasova et al., 2017; Huelgas \& Funamizu, 2010; Jong et al., 2010; Merz et al., 2007) } \\
\hline \multicolumn{7}{|c|}{ f (Abdel-Shafy et al., 2015; Elmitwalli et al., 2007; Hernandez Leal et al., 2010) } \\
\hline
\end{tabular}




\section{Naturally occurring greywater treatment media}

These are naturally occurring materials that have been applied as either standalone media or used as a complementary medium in some of the available conventional greywater treatment systems. Many researchers have studied the effect of treatment offered by these media and their performance is listed in table 2.5. Unlike other conventional treatment systems, these media are used for removing targeted contaminants and their mode of treatment is either by adsorption, filtration or coagulation.

\begin{tabular}{|c|c|c|c|c|}
\hline Type of material & $\begin{array}{l}\text { Target pollutant } \\
\text { removal }\end{array}$ & $\begin{array}{l}\text { Percentage } \\
\text { removal }\end{array}$ & $\begin{array}{l}\text { Mode of } \\
\text { removal }\end{array}$ & Source \\
\hline \multirow[t]{4}{*}{ Activated carbon } & $\mathrm{BOD}_{5}$ & $97 \%$ & Adsorption & (Sahar et al., 2012) \\
\hline & COD & $94 \%$ & & \\
\hline & TN & $98 \%$ & & \\
\hline & TP & $91 \%$ & & \\
\hline \multirow[t]{2}{*}{ Activated Charcoal } & EC & $12 \%$ & Adsorption & (Dalahmeh et al., 2012) \\
\hline & $\mathrm{BOD}_{5}$ & $97 \%$ & & \\
\hline Peat Moss and Lime & COD & $90 \%$ & Filtration & \\
\hline \multirow[t]{2}{*}{ pebbles } & $\mathrm{BOD}_{5}$ & $95 \%$ & & \\
\hline & E.Coli & $100 \%$ & & \\
\hline \multirow[t]{4}{*}{ Pine Bark } & $\mathrm{BOD}_{5}$ & $98 \%$ & Adsorption & (Sahar et al., 2012) \\
\hline & COD & $74 \%$ & & \\
\hline & TN & $19 \%$ & & \\
\hline & TP & $97 \%$ & & \\
\hline \multirow[t]{7}{*}{ Moringa oliefera } & COD & $64 \%$ & Coagulation & (Bhuptawat, Folkard, \& \\
\hline & & & & Chaudhari, 2007) \\
\hline & Turbidity & $98 \%$ & & (Hendrawati et al., 2016) \\
\hline & Conductivity & $11 \%$ & & \\
\hline & $\mathrm{BOD}_{5}$ & $12 \%$ & & \\
\hline & Turbidity & $96 \%$ & & (Effendi, Sari, \& Hasibuan, \\
\hline & TSS & $88 \%$ & & 2015) \\
\hline \multirow[t]{4}{*}{ Saw dust } & TSS & $83 \%$ & Filtration & (Parjane \& Sane, 2011) \\
\hline & TDS & $70 \%$ & & \\
\hline & O\&G & $97 \%$ & & \\
\hline & COD & $82 \%$ & & \\
\hline
\end{tabular}

\section{Reuse strategies}

A number of greywater treatment and reuse schemes have been implemented across the globe using both conventional and hybrid systems. Most of these systems have been developed as an environmental intervention measure and have since been operational while some have had their own challenges from both the technical and public point of view. Table 6 presents some examples of successful application of greywater treatment and reuse schemes in some countries. 


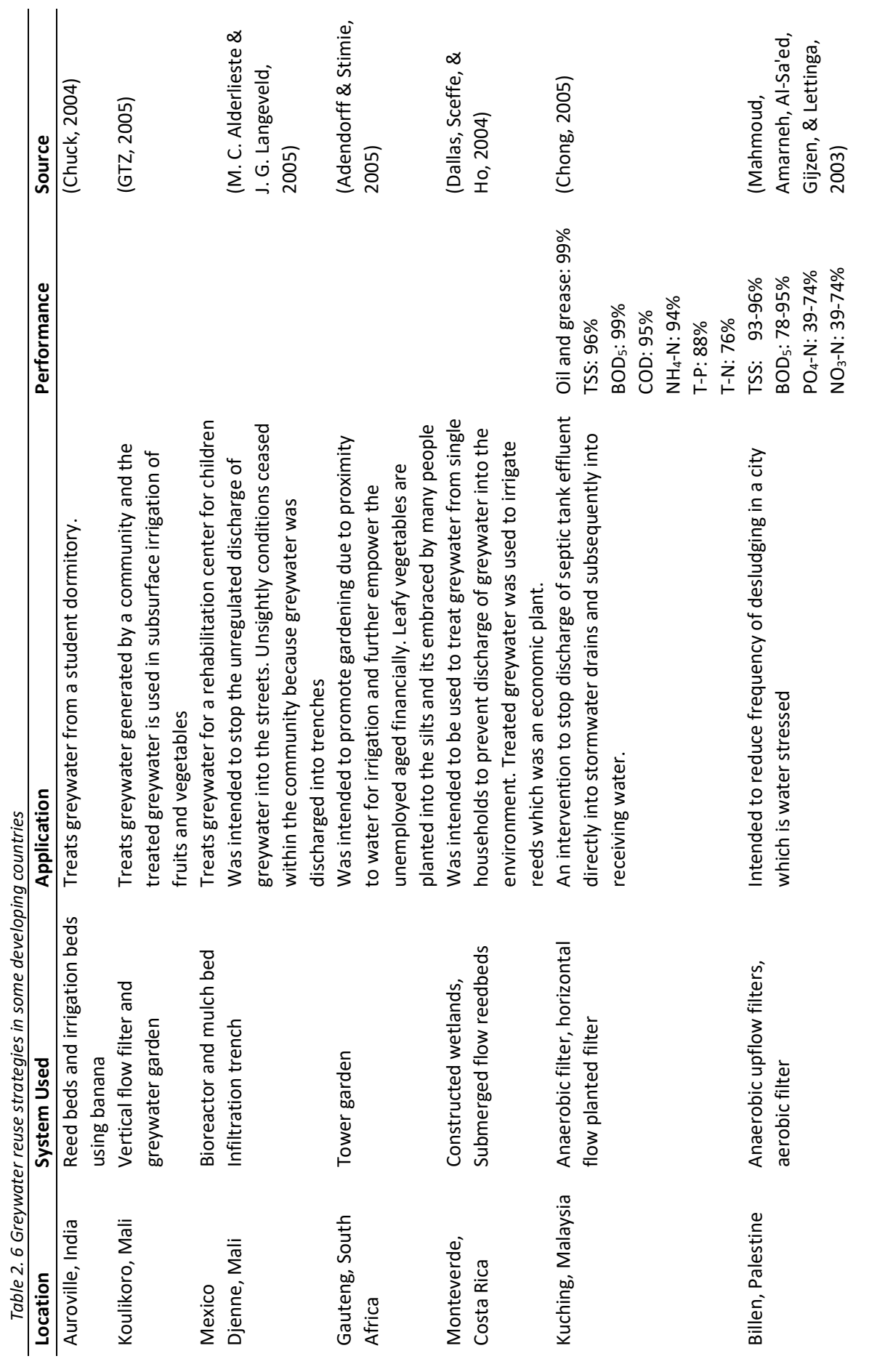




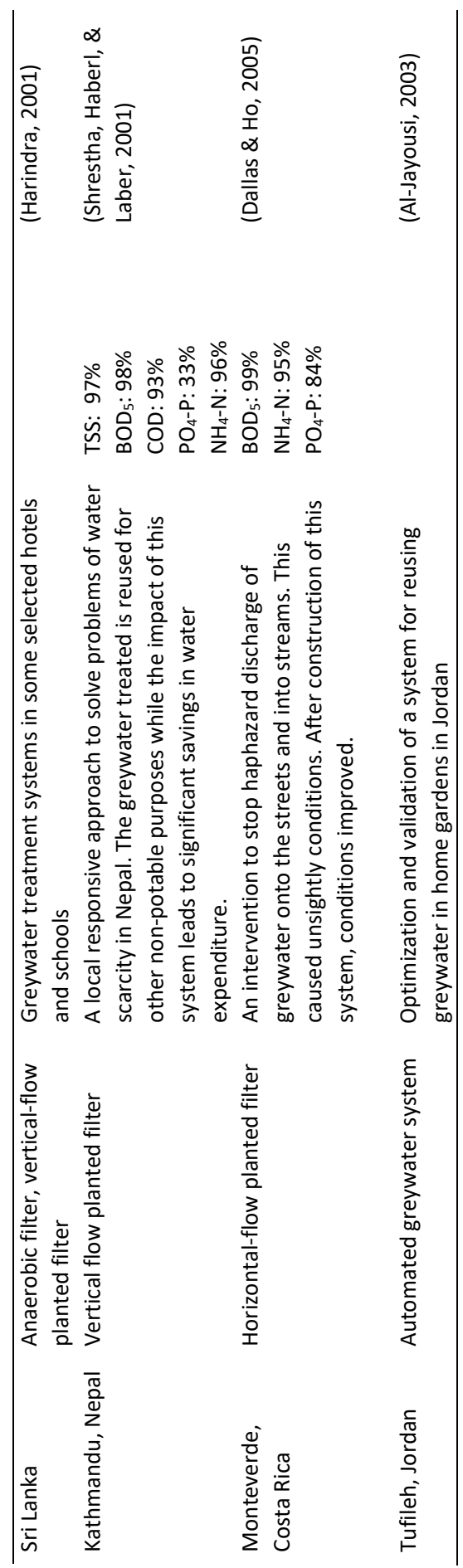




\section{Greywater reuse perceptions}

Public perception which is a social phenomenon can be seen as the difference between an absolute truth based on facts and virtual truth shaped by popular opinion (Conjucture, 2017). In implementation of any project public perception has been recognized as an integral factor in determining the success of the project. Many technically sound and environmentally friendly programs have failed because it was not accepted by the intended beneficiaries. Several studies have been conducted to assess public perception towards greywater reuse in different parts of the world using different strategies. These strategies include interviews, questionnaires, focus group discussions, informal discussions and other equally good social surveys. Most of these surveys identified clear support for the concept of greywater reuse as an environmentally sustainable method of protecting freshwater resources and pollution prevention. It has been reported by (Dolnicar \& Schafer, 2006; Friedler, Lahav, Jizhaki, \& Lahav, 2006; Hurliman \& McKay, 2007; Kantanonleon, Zampetakis, \& Manios, 2007; Marks, 2004) that the highest acceptability of greywater reuse schemes are for non-potable uses. S Dolnicar and Schafer (2006) identified reduced levels of acceptance as the recycled water got closer to human contact. A similar study by Jeffery (2001) in the United Kingdom identified that people were more willing to use 'own' recycled greywater than to use recycled water from an unknown source. Alhumoud and Madzikanda (2010) identified that public support was greater for areas which are water stressed and areas with unreliable water supply. The results of a study by Adewumi, Olanrewaju, llemobade, and van Zyl (2010) conducted in three universities in South Africa among students and staff concluded that the level of education and level of awareness contributes to the success of greywater reuse. Religious and cultural practices have been identified as factors that influence reuse programs. This is supported by another study by (DeSena, 2006; Parkinson, 2008) who identified misinformation, lack of knowledge or instinctive repugnance as accounting for objections in reuse programs.

\section{Potable reuse perceptions}

The interruption and complete obstruction of many potable water reuse projects by stiff public opposition have been reported by (DeSena, 2006; Hurliman \& Dolnicar, 2013; Meehan, Ormerod, \& Moore, 2013). This stiff opposition to potable reuse has been attributed to the close association of greywater with sewage which creates a phenomenon known as wisdom of repugnance. This phenomenon assumes that recycled water is associated with human waste therefore it renders it unpalatable from the public's point of view. A study by Marks (2004) in three developed countries (Australia, United States and United Kingdom) identified low public support and acceptance for greywater reuse for potable purposes. The main barrier encountered in these studies were the associated perceived health risk of reusing recycled water in activities that involve direct contact with the user. Other studies identified language of the names given to recycled water as one of the obstacles affecting reuse schemes (Dolnicar \& Saunders, 2006). A study by (Friedler, Lahav, et al., 2006; Omerod \& Scott, 2013; Russell, Lux, \& Hampton, 2009) identified public trust arising out of a combination of technical and non-technical issues. The study identified strong public opposition to reuse projects where there is little trust in the implementing body even in the face of the most advanced technology applicable. Currently most of the research in this area is targeting determinants that increases acceptance of reuse programs.

\section{Conclusions}

This study reviewed greywater characteristics, treatment systems, reuse strategies and perception of greywater reuse among users. It shows that there is a wide variation in greywater characteristics and volume generation rates which is largely dependent on the water use, lifestyle patterns and type of 
settlement. From the list of reviewed conventional treatment systems, filtration methods seem feasible and has the potential of integration with other systems to achieve target specific treatment. The study described different reuse strategies, most using discharged greywater for food production and landscaping while others have been used for poverty alleviation in irrigation farming.

The available technologies have been developed to treat or remove specific pollutants and not offer a full treatment of the greywater. Moreover, quality criteria differ for each type of reuse application and greywater composition and generation rates vary greatly from one point to the other. It will therefore be prudent if systems are designed to target a specific reuse option taking into consideration the regional variability and complexities such that effluent from a treatment system will meet the required effluent guidelines. All the treatment systems reviewed were applicable on large scale and cannot be applied at the household level. This in our view discourages local level participation in greywater reuse schemes. From the review the potential of some natural materials to be used as media in greywater treatment systems also emerged. These natural materials are widely available in most developing countries and their total integration into the conventional treatment systems should be explored. They can be used to design simple household level greywater treatment systems that target a certain reuse option and thereby increase local level participation.

Perception of greywater reuse has been closely related to the choice of reuse as most users will want to reuse greywater for activities that do not involve personal contact. In general, public perceptions are important to consider when implementing a certain method for a specified use. On the basis of this review we conclude that to achieve effective greywater treatment and reuse, extensive contributions from technical and non-technical experts in many disciplines are called for. It also requires a comprehensive assessment of the greywater characteristics in order to choose an appropriate method or system of treatment. That notwithstanding, greywater treatment and reuse if embraced and enforced can lead to substantial decline in over-reliance on freshwater resources for non-potable uses. 


\section{Chapter three}

\section{Published as:}

Oteng-Peprah, M., de Vries, N. K., \& Acheampong, M. A. (2018). Greywater characterization and generation rates in a peri urban municipality of a developing country. J Environ Manage, 206, 498-506. doi:10.1016/j.jenvman.2017.10.068 


\begin{abstract}
The quantity and quality of combined greywater from houses with in-house water supply and houses that rely on external sources of a peri-urban area in a developing country were determined. Data for quantity of greywater was collected from 36 households while 180 samples of greywater were collected from 60 households between December 2016 and February 2017. The results indicate that, average water consumption from households with in-house access was $82.51 \pm 12.21 \mathrm{Lc}^{-1} \mathrm{~d}^{-1}$ while households which rely on external sources was $36.64 \pm 4.31 \mathrm{Lc}^{-1} \mathrm{~d}^{-1}$ with return factors of $74.16 \%$ and $88.57 \%$ respectively. Quality analysis also showed significant differences between greywater from the two sources with most of the quality parameters exceeding the regulatory limit. The ratio between biochemical oxygen demand $\left(\mathrm{BOD}_{5}\right)$ and chemical oxygen demand (COD) ranged between $0.22-0.59$ for greywater from in-house sources and 0.23-0.62 for external sources indicating low biodegradability of the greywater. The nutrients recorded exceeded the trigger levels for eutrophication while significant levels of microorganisms such as E.Coli and Salmonella spp. were also detected in both streams. Direct reuse of greywater for irrigation was found to be unsuitable based on the salinity and sodium hazard analysis. Principal component analysis of the data indicated that the characteristics of the combined greywater in the study area is influenced by cooking and cleaning practices, personal hygiene, biodegradability, frequency of water use before disposal and sanitary practices in the bathroom. The greywater discharged is detrimental to the environment and poses a health risk to humans and livestock. There is therefore the need for authorities involved to prioritize greywater management and treatment in peri-urban areas of developing countries.
\end{abstract}

\section{Keywords:}

Peri-urban, Greywater, in-house, outside source, Ghana 


\section{Introduction}

The united nations define a peri-urban area as an area between consolidated urban and rural region (UNICEF, 2012). In developing countries, it is where poverty and social displacement are more common, a frontline between the problems of the city and the rural areas. The growth of these peri-urban areas in developing countries are associated with sanitation challenges such as solid waste, excreta collection and management and wastewater management for the relevant institutions. Due to the disparities in economic and social status associated with peri-urban areas in developing countries, certain basic amenities like water supply within a house is not automatic for every house. Houses without piped water in their dwelling will have to resort to other sources of water such as from water vendors, springs, streams among others. Many of these peri-urban areas in developing countries are saddled with wastewater management largely due to the non-existence of sewer network. The primary focus on peri-urban areas by authorities has remained solid waste and excreta management which is aimed at improving the sanitary conditions and improving public health. However, this is in sharp contrast to greywater management which accounts for the high volumetric flux of wastewater generated in non-sewered areas. There is a clear lack of planning in addressing greywater management in peri-urban areas in developing countries mostly arising from lack of commitment or by the overwhelming rapid growth associated with these areas. Lack of proper management of greywater in peri-urban areas of developing countries has led to indiscriminate discharge of greywater, which has contributed to public health issues arising out of uncontrolled and unmonitored discharges. These discharges result in both short term and long-term effects on both environment and human (Gross et al., 2005; Scott \& Jones, 2000). It also affects water resources and soils due to the presence of surfactants, (Mohamed, Kassim, Anda, \& Dallas, 2013), heavy metals (Aonghusa \& Gray, 2002; Eriksson et al., 2010) in high quantities. Nutrient buildup in water bodies as a result of greywater discharge may lead to eutrophication which is detrimental to aquatic environment. (Kohler, 2006) in his research identified sodium polyphosphate which is a major ingredient in soaps to be a major contributor of nutrients in eutrophication. Studies conducted by (Escher \& Fenner, 2011; Taghipour \& Mosaferi, 2013) identified a distortion in the ecological balance due to toxicity of food chain caused by accumulation of heavy metals and micro-pollutants in the environment which negatively affects both plants and animals alike after long exposure times. Long periods of exposure to pathogens and microorganisms in greywater has been reported to cause diseases that results in either mortality or morbidity (Birks \& Hills, 2007; Ottoson \& Stenstrom, 2003). Many studies have all analyzed greywater without cognizance to the source of water and the lifestyle patterns. Research on greywater characterization and quantity generations has largely focused on sources such as kitchen, bathroom, hand wash basin (Abedin \& Rakib, 2013; Katukiza et al., 2014), water use fixtures such as washing machines, dishwashers (Abedin \& Rakib, 2013; O'Toole et al., 2012) and location or type of settlement such as periurban and slums, (Antonopoulou, Kirkou, \& Stasinakis, 2013; do Couto et al., 2013; Katukiza et al., 2014; Ramona, Green, Semiat, \& Dosoretz, 2004).

However, the differences in quality and quantity between greywater from houses fitted with household taps and those that rely on other external sources of water in a peri-urban area in a developing country remains uninvestigated. According to the UNDP (2017), about 663 million people lack access to improved water and a majority of this fraction are in developing countries. This is an indication that greywater discharges from peri-urban areas in developing countries should not be treated as all coming from one source as has always been the case in many studies that have characterized greywater quality and quantities.

The objective of this study therefore is to characterize greywater and quantify its pollutant loads for these two categories in a typical peri-urban area of a developing country within sub-Saharan Africa and provide the relevant data necessary to policy makers to inform decision and influence policy. 


\section{Materials and methods}

\section{Study area}

This study was conducted in the Komenda Edina Eguafo Abirem (KEEA) municipality of the Central region of Ghana during the periods of December 2016-February 2017. KEEA is located in the central region of Ghana between longitude $1^{\circ} 20^{\prime}$ West and $1^{\circ} 40^{\prime}$ West and latitude $5^{\circ} 05^{\prime}$ North and $15^{\circ}$ North and covers an area of $452.5 \mathrm{~km}^{2}$ with a population of 144,705 (GSS, 2014). It is located within the coastal belt of the country along the Atlantic Ocean and it is drained by the Benya lagoon. Potable water supply to the area is exclusively by Ghana Water Company Limited (GWCL) which has a network coverage of less than $40 \%$ within the municipality while other areas which are not connected to the GWCL lines resort to alternative water supply systems such as groundwater, streams and springs, rainwater and water vendors. Greywater is discharged through open gutters and undeveloped plots. Other methods of disposal also include direct irrigation of certain plant species such as Musa Balbisiana, Carica Papaya among others and open discharge onto compounds in areas where there are no gutter or undeveloped plots. Majority of residents use on-site sanitation systems such as septic tanks and household latrines while others rely on public sanitation facilities. These practices are mostly common in peri-urban areas in developing countries within the sub-Sahara Africa, Latin America, and Asia. There is no wastewater management system in place and wastewater is discharged without any regulation. This survey was done in different towns/villages within the study area in order to have a cross-sectional variation in water use and greywater generation rates and also simulate similar conditions in other developing countries.

\section{Selection of households: Characterization}

Greywater samples were collected from all six zonal councils within the study area. A total of one hundred and eighty (180) samples were collected from the study area. Sixty households were selected to participate in the study within the six zonal councils after consultation with local leaders within the community. The criteria for selecting these households were willingness to participate in the study, households with in-house access, households that rely on outside sources, households with children under age 3, households that have greywater from kitchen, hand wash basin and bathrooms going through one discharge point. Volunteers were asked to discharge water used for laundry into this drain during the periods of data collection. 


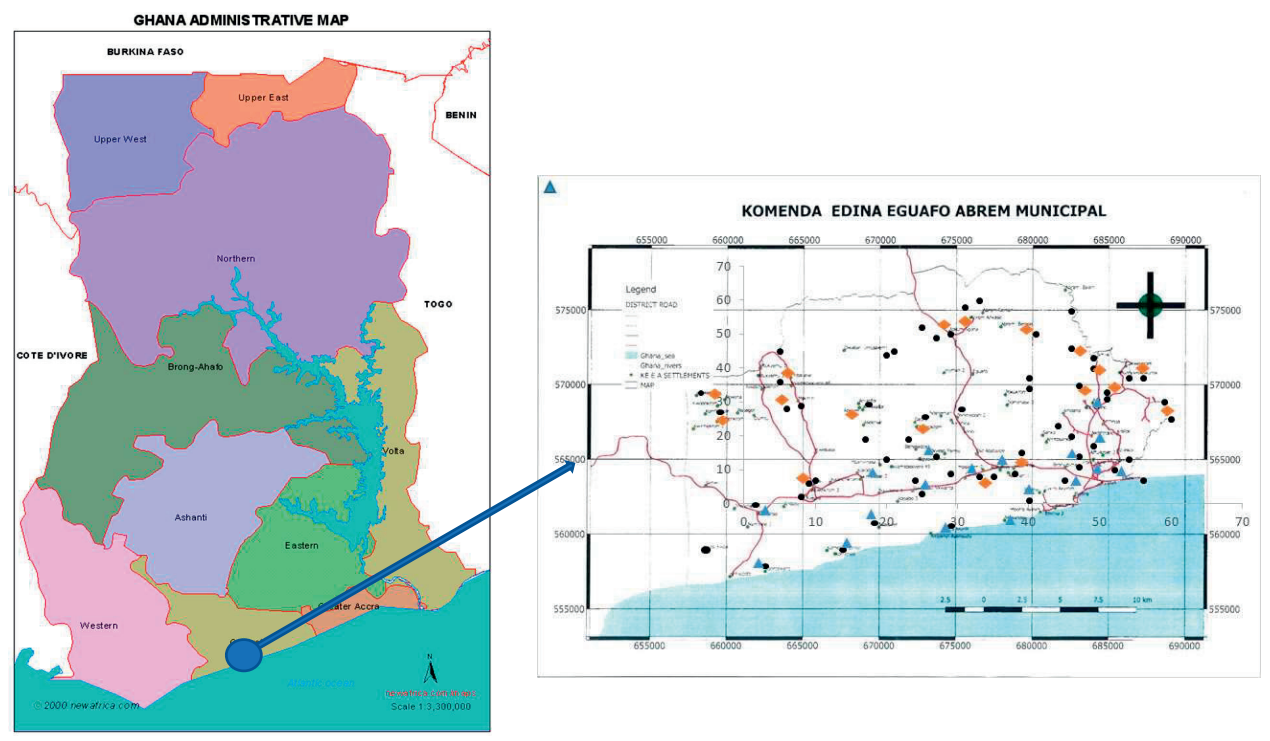

Figure 3. 1 Map of study area with sampling points

\section{Selection of households: Volume estimation}

Volume estimation was done by recruiting two sets of volunteers - those with in-house access and those who rely on an outside source. Criteria for selection of volunteers with in-house access was willingness to participate in the study. With respect to those who rely on outside sources, the criteria for selecting such volunteers were willingness to participate, willingness to use special $20 \mathrm{~L}$ buckets provided for the study to collect both potable and greywater after use.

\section{Collection of greywater samples: Quality estimation}

Greywater samples $(n=180)$ were collected and stored in sterilized $0.5 \mathrm{~L}$ sample bottles and $0.2 \mathrm{~L}$ sterilized glass bottle for oil and grease analysis. The sampling points indicated with round dots are shown in figure 3.1. These samples were stored in laboratory ice chest with ice packs and transported to the laboratory for analyses within 24 hours.

\section{Collection of greywater samples: Volume estimation}

A total of 18 households with in-house access were provided with a special digital flow meter - white-line smart flowmeter. The discharge spouts of their wastewater discharge lines were retrofitted in order to install this flowmeter. This flowmeter is not disturbed by solids and has a very low sensitivity $\left(0.5 \mathrm{Lmin}^{-1}\right)$. However, the drawback of this flowmeter is its inability to read more than $1000 \mathrm{~L}$. Volunteers were alerted of this and were given a tally card to record the number of times it resets itself after recording 1000L. The volume recorded on the water meter supplied by GWCL is taken before the study was initiated in order to estimate the volume of water that will be used by the household. Sampling points represented by triangle are presented in figure 3.1. Participants were also asked to note any day when there was no water supply.

A total of 18 households that relied on outside sources were selected in this study. These households were given special $20 \mathrm{~L}$ buckets for use during the study period to help estimate the quantity of water used. To help estimate the volume of greywater discharged, they were asked to pour greywater generated into 
these $20 \mathrm{~L}$ buckets before final disposal. A tally card indicating the number of times the bucket got full and was emptied and the number of times they fetched water with the bucket was given to each household. Sampling points represented by diamond is presented on figure 3.1.

\section{Laboratory analysis}

The following parameters: $\mathrm{pH}$, Dissolved Oxygen (DO), Electrical Conductivity (EC) and Total Dissolved solids (TDS) were measured on site using a Horiba U-50 multi parameter water quality meter. The concentrations of Nitrate-nitrogen $\left(\mathrm{NO}_{3}-\mathrm{N}\right)$, Ammonium-nitrogen $\left(\mathrm{NH}_{4}-\mathrm{N}\right)$, Total Suspended Solids (TSS), Chloride $\left(\mathrm{Cl}^{-}\right)$and Potassium (K) were measured using a $\mathrm{HACH}$ DR6000 spectrophotometer according to $\mathrm{HACH}$ methods $8171,8006,8113$ and 8049, respectively. The five-day Biochemical Oxygen Demand $\left(\mathrm{BOD}_{5}\right)$ concentration was determined using the Lovibond BD 606 BOD system. The concentration of Chemical Oxygen Demand (COD) was determined using the closed reflux colorimetric method as stated in (APHA) 5220C. The concentration of Sodium $\left(\mathrm{Na}^{+}\right)$was determined with flame photometer while total phosphorous (T-P) was determined using the persulfate method as stated in (APHA) 4500-P. Oil and grease concentrations were determined using the partition gravimetric method as stated in the (APHA) 5520-B. Concentrations of Magnesium $\left(\mathrm{Mg}^{2+}\right)$ and Calcium $\left(\mathrm{Ca}^{2+}\right)$ were determined with atomic absorption spectrometric method using a Varian AA 50 spectrometer. The bacteriological parameters (Total coliforms, E.coli and Salmonella spp.) were determined with chromocult coliform agar media using spread plate method as outlined in the (APHA) 9215C.

\section{Statistical analysis}

Independent t-tests were used to determine the statistical significance in the parameters measured between greywater from In-house and outside sources. Principal component analysis (PCA) was used to reduce the dimensionality of the data from 17 to 5 using Oblique rotation (direct oblimin). An oblique rotation is recommended if there is a good reason to suppose that the underlying factors could be related in theoretical terms (Field, 2014). This method of rotation was adopted because there is theoretical evidence that suggests some of the factors may be related. PCA is used to reduce a data set to a more manageable size while retaining as much of the original information as possible. All statistical analyses were carried out using IBM SPSS statistics 21 and Microsoft Excel.

\section{Results and Discussion}

\section{Water consumption and greywater volume generation}

Independent sample t-tests were conducted to compare water consumption, greywater generation and return factors between in-house access and outside access. Summary results are presented in Table 3.1.

Table 3. 1 T-test Results of water consumption and greywater generation rates

\begin{tabular}{llllll}
\hline & Outside Source & In-house Access & \multicolumn{2}{l}{ t-test for equality of means } \\
\cline { 4 - 6 } & $N=18$ & $N=18$ & $\mathrm{p}$ & $\mathrm{t}$ & $\mathrm{df}$ \\
\hline Water Consumption $\left(\mathrm{LC}^{-1} \mathrm{~d}^{-1}\right)$ & $36.64( \pm 4.3)_{\mathrm{a}}$ & $82.51( \pm 12.21)_{\mathrm{b}}$ & 0.00 & 15.02 & 34 \\
Greywater generation $\left(\mathrm{LC}^{-1} \mathrm{~d}^{-1}\right)$ & $32.44( \pm 3.83)_{\mathrm{a}}$ & $73.41( \pm 11.01)_{\mathrm{b}}$ & 0.00 & 14.91 & 34 \\
Return factor \% & $88.57( \pm 3.4)_{\mathrm{a}}$ & $74.16( \pm 2.56)_{\mathrm{b}}$ & 0.00 & 14.32 & 34
\end{tabular}

Values in the same row not sharing the same subscript are significantly different at $p<.05$ in the two-sided test of equality for in-house and outside source greywater.

The average water consumption of and $36.64 \mathrm{Lc}^{-1} \mathrm{~d}^{-1}$ for outside access and $82.51 \mathrm{Lc}^{-1} \mathrm{~d}^{-1}$ for in-house source were above the minimum recommended value of $30 \mathrm{LC}^{-1} \mathrm{~d}^{-1}(\mathrm{UNICEF}, 2016)$ but below the national average 
of $100 \mathrm{Lc}^{-1} \mathrm{~d}^{-1}$ (GWCL). These differences can be attributed largely to lifestyle and sanitation facilities and practices adopted by these two groups. The water consumption recorded for in-house access falls within the range of a similar study in South Africa by (CSIR, 2001; Schalkwyk, 1996), which recorded water consumption within $30-100 \mathrm{Lc}^{-1} \mathrm{~d}^{-1}$ for in-house access. The return factors of $88.57 \%$ and $74.16 \%$ recorded for this study were within the range reported by other studies (Alderlieste \& Langeveld, 2005; Busser et al., 2006; Faraqui \& Al-Jayyousi, 2002; Shresta, 1999). These results suggest that access to in-house connection is likely to lead to increase in water consumption and its associated greywater generation. The high return factor recorded for greywater from outside access can be attributed to sanitation and hygiene practices. Most people under this category use dry sanitation systems such as pits or patronize public sanitation facilities. It could also be attributed to other factors such as distance, reliability of source and many other latent factors. It has been reported that households with dry latrines can record as high as $100 \%$ return factors (SANDEC, 2006). Studies of greywater generation rates from different sources is presented in Table 3.2.

Table 3. 2 Rates of greywater generation from in-house and outside water sources reported in similar studies

\begin{tabular}{llll}
\hline Location & $\begin{array}{l}\text { Generation } \\
\left(\mathrm{Lc}^{-1} \mathrm{~d}^{-1}\right)\end{array}$ & Water source & Reference \\
\hline South-Africa & 20 & Outside source & (Adendorff \& Stimie, 2005) \\
Mali & 30 & Outside source & (Alderlieste \& Langeveld, 2005) \\
Nepal & 72 & In-house source & (Shresta, 1999) \\
Vietnam & $80-110$ & In-house source & (Busser et al., 2006) \\
Jordan & 50 & In-house source & (Faraqui \& Al-Jayyousi, 2002) \\
Ghana & 32 & Outside source & This study \\
Ghana & 73 & In-house source & This study
\end{tabular}

\section{Greywater characteristics}

Summary results of independent t-tests on greywater quality parameters comparing in-house and outside source is presented in Table 3.3. Most of the physical parameters measured exceeded the permissible limits set by the regulating agency which is the Environmental Protection Agency of Ghana (EPA). The pH recorded was within a range of $5-8$ but the average $\mathrm{pH}$ of 7 was within the acceptable range of $6-9$. The extreme $\mathrm{pH}$ of 5 recorded in some of the samples could be attributed to organic acids produced by edible organic compounds while the high $\mathrm{pH}$ of 8 could be partly attributed to the use of sodium hydroxide-based soaps. However, there is no significant difference between the $\mathrm{pH}$ recorded in both groups ( $p=.62$ ). This indicates that having in-house source or relying on outside source has no influence on the $\mathrm{pH}$ of the greywater generated. The average values of (DO) recorded within the study area were within the acceptable limits. However, the range recorded showed some samples which were below the acceptable limits set by the EPA. Although no significant differences were observed between these two groups the low DO recorded could be attributed to water storage practices which is very common within the study area. Low dissolved oxygen impairs aquatic organisms and also creates septic conditions for water. The average electrical conductivity (EC) of $2,044 \mu \mathrm{Scm}^{-1}$ for outside sources and $1617 \mu \mathrm{Scm}^{-1}$ for 
in-house sources recorded were above the regulatory limit of $750 \mu \mathrm{Scm}^{-1}$ for both groups. There is a significant difference $(p=.00)$ between the two groups, which implies EC of greywater from outside sources is higher than in-house sources. This could be due to extensive use of water in the form of internal recycling practices such as reusing laundry water for scrubbing or rinsing cooking pots and pans in the same bowl of water, which are mostly practiced by houses that rely on outside source. This internal recycling leads to massive buildup of dissolved ions in the water, which increases the electrical conductivity. It could also be from the sources of water, which might largely be groundwater sources. Since the study area is close to the sea, groundwater supplies could have very high EC. This phenomenon is also confirmed in the results from the Total Dissolved Solids. The average TDS of $1,288 \mathrm{mgL}^{-1}$ recorded for greywater from outside sources is higher than concentration of $1,010 \mathrm{mgL}^{-1}$ recorded for greywater from in-house sources, which is statistically significant at $p=.00$. The TDS concentrations for both groups also exceed the regulatory guideline limits of $50 \mathrm{mgL}^{-1}$. TDS is largely due to the presence of salts and other dissolved fractions in greywater. A linear trend with positive slope shows a significant correlation between these two parameters, which is also established in other studies (Tchobanoglous, Burton, \& Stensel, 2003) that TDS is a factor of EC.

The concentration of Total Suspended Solids (TSS) for both groups were below the regulatory limits. The TSS measured also indicate that greywater from in-house sources had lower TSS concentration of 269 $\mathrm{mgL}^{-1}$ than that of $538 \mathrm{mgL}^{-1}$ from outside sources, the difference of which is statistically significant $(p=.00)$. These differences in concentrations can be attributed to the quantity of water used. High total suspended solids in greywater can lead to cloudiness in the receiving water body, impair visibility and cause reduction in dissolved oxygen in the receiving water body. It can also lead to buildup of sediments in the receiving water body or drain and create suitable conditions for flooding. The high concentration recorded for greywater from outside sources could be due to the repeated use of water for different activities before it is finally disposed.

The average concentration of $\mathrm{BOD}_{5}$ for in-house access was $204 \mathrm{mgL}^{-1}$ and outside access was $253 \mathrm{mgL}^{-1}$ while the COD concentrations were $644 \mathrm{mgL}^{-1}$ for in-house and $744 \mathrm{mgL}^{-1}$ for outside access. This difference is statistically significant at $\mathrm{p}=.05$ and $\mathrm{p}=.00$ for $\mathrm{BOD}_{5}$ and $\mathrm{COD}$ respectively. Comparing the concentration range of greywater from outside sources to greywater from in-house sources, which is $\mathrm{BOD}_{5}$ of $61.5 \mathrm{mgL}^{-1}-301 \mathrm{mgL}^{-1}$ and COD of $207 \mathrm{mgL}^{-1}-1,299 \mathrm{mgL}^{-1}$, it can be seen that all the concentrations are above the permissible limits set by the regulatory agency. This indicates that greywater from outside sources had higher $\mathrm{BOD}_{5}$ and COD than those from in-house source. This could be due to some form of internal recycling within the house before the greywater is finally discharged, hence, accounting for the higher concentration of biodegradable and non-biodegradable materials within the greywater. It could also be attributed to excessive disposal of biodegradable and non-biodegradable materials into greywater. Nevertheless, $\mathrm{BOD}_{5}$ and $\mathrm{COD}$ values recorded for both areas were within the range for greywater (Tchobanoglous et al., 2003). The relatively low values recorded for in-house source may, however, be attributed to dilution. Therefore, discharging greywater with high $\mathrm{BOD}_{5}$ and $\mathrm{COD}$ concentrations into drains and surface water can result in oxygen depletion and impair aquatic life. A similar study have reported $\mathrm{BOD}_{5}$ ranges of $102-215 \mathrm{mgL}^{-1}$ and $\mathrm{COD}$ of $425-1583 \mathrm{mgL}^{-1}$ for greywater (Hernandez, Leal, Zeeman, Temmink, \& Buisman, 2007).

The concentration of Sodium $\left(\mathrm{Na}^{+}\right)$in greywater samples from outside sources, which is $140 \mathrm{mgL}^{-1}$ was significantly higher than that of in-house source of $119 \mathrm{mgL}^{-1}$ at $p=.00$. The concentration of both groups exceeded the regulatory limit. The differences observed can be attributed to the type of soaps used by both groups. The source of $\mathrm{Na}^{+}$could be from cooking salt and detergents. Dilution or the source of water can also play a role in the marked differences recorded between these two groups. The presence of $\mathrm{Na}^{+}$ 
in greywater can lead to $\mathrm{Na}^{+}$buildup within the environment, which is detrimental to plant growth (Tavakkoli, Fatehi, Coventry, Rengasamy, \& McDonald, 2011). It also increases the electrical conductivity of water as well as its Total Dissolved Solids. The results obtained in this study is within the range reported in a similar study by Leal, Zeeman, and Buisman (2011), which reported $\mathrm{Na}^{+}$concentrations of 123-144 $\mathrm{mgL}^{-1}$. The average concentrations of chloride $(\mathrm{Cl})$, potassium (K), calcium $\left(\mathrm{Ca}^{2+}\right)$ and magnesium $\left(\mathrm{Mg}^{2+}\right)$ from outside source were slightly higher than in-house sources. The observed differences are statistically significant at $\mathrm{p}=.00$ for $\mathrm{Ca}^{2+}, \mathrm{p}=.00$ for Magnesium and $\mathrm{p}=.00 \mathrm{for} \mathrm{Cl}^{-}$and $\mathrm{p}=.01$ for potassium. The presence of $\mathrm{Cl}^{-}$can be attributed to the use of table salt for cooking. $\mathrm{Cl}^{-}$has also been reported as being a component of urine (Tchobanoglous et al., 2003) suggesting the practice of urination during showering also contributes chlorine into greywater. The difference in the $\mathrm{Cl}^{-}$concentrations between these groups can be due to dilution and cooking practices. The presence of excessive concentration of $\mathrm{Cl}^{-}$in the environment may impact freshwater organisms and plants by increasing species mortality and changing reproduction rates (WHO, 1996). $\mathrm{Cl}^{-}$ions can also percolate down into the water table and affect groundwater quality. There were significant differences between concentration of $\mathrm{K}$ for outside source and in-house source. Greywater from outside sources recorded an average concentration of $10.9 \mathrm{mgL}^{-1}$ while in-house sources recorded an average of $9.0 \mathrm{mgL}^{-1}$. The presence of $\mathrm{K}$ could also be from use of certain potassium-based soaps. $\mathrm{K}$ may contribute nutrients to a receiving water body or environment and promote eutrophication in ponds and streams. The results obtained for $\mathrm{K}$ in this study falls within a similar study by (Christova-Boal, Eden, \& McFarlane, 1996; Hernandez et al., 2007) which reported concentrations of $\mathrm{K}$ within $8.13-15.2 \mathrm{mgL}^{-1}$.

\section{Oil and grease}

Although the concentrations of oils and grease from greywater from outside sources of $67 \mathrm{mgL}^{-1}$ was slightly higher than that from in-house source of $66 \mathrm{mgL}^{-1}$, this difference is not significant $(p=.86)$. From the 180 samples taken, $81 \%$ recorded positive results for oil and grease. This is to be expected since mixed greywater samples include greywater from the kitchen, where oil and grease are mostly used. ChristovaBoal et al. (1996) also recorded oils and grease in greywater within a concentration range of $37-78 \mathrm{mgL}^{-1}$. Oil and grease in greywater is a major concern because of the translucent film it forms on the surface of water blocking the water-oxygen interface, which is detrimental to aquatic life. In an area where there are limited major drains, current practices of open disposal of greywater may impair soil porosity and ultimately affect infiltration, which can lead to flooding in the extreme circumstances.

\section{Nutrients}

The average concentration of $\mathrm{NH}_{4}-\mathrm{N}$ for greywater from outside and in-house sources were both 14.8 and $14.4 \mathrm{mgL}^{-1}$ respectively. However, this observed difference was not statistically significant $(p=.35)$. The average values recorded for $\mathrm{NH}_{4}-\mathrm{N}$ in both groups seems to deviate from what has been widely reported in literature. However, Katukiza et al. (2014) has also reported $\mathrm{NH}_{4}-\mathrm{N}$ values for greywater within the range of 22-33 $\mathrm{mgL}^{-1}$. This indicates that the levels of $\mathrm{NH}_{4}-\mathrm{N}$ recorded in this study and other studies are all above the regulatory limit. The average concentration of $\mathrm{NO}_{3}-\mathrm{N}$ for greywater samples from outside sources and in-house source had the same average values of $2.5 \mathrm{mgL}^{-1}$. These results were, however, not statistically significant ( $p=.87$ ). Katukiza et al. (2014) also recorded $\mathrm{NO}_{3}-\mathrm{N}$ in greywater samples within the range of 1.9-3.1 $\mathrm{mgL}^{-1}$. Since $\mathrm{NH}_{4}-\mathrm{N}$ is not used in production of soap, the most probable source of $\mathrm{NH}_{4}-\mathrm{N}$ and $\mathrm{NO}_{3}-\mathrm{N}$ in greywater might be from urine, which can be explained by the habit of some users probably urinating during showers and also from mineralization of organic materials from kitchen.

The Total Phosphorous (TP) concentrations for greywater from outside sources and in-house were both $2.3 \mathrm{mgL}^{-1}$, but these average concentrations were not statistically significant $(p=.72)$. (Elmitwalli \& Otterpohl, 2007) in a study on greywater also recorded $\mathrm{NO}_{3}-\mathrm{N}$ concentrations within the range of $5.2-$ $6.3 \mathrm{mgL}^{-1}$, which were slightly higher than what is recorded in this study. The main sources of phosphorous 
are soaps and cleaning materials. The concentration of these nutrients recorded in this study exceed the trigger values of $0.1 \mathrm{mgL}^{-1}$ for TP, $0.1 \mathrm{mgL}^{-1}$ for $\mathrm{NO}_{3}-\mathrm{N}$ and $0.01 \mathrm{mgL}^{-1}$ for fresh water which is stated by ANZECC (2000). This implies their continued buildup within the environment can lead to excessive eutrophication in streams and water bodies. The presence of nutrients suggests that the nutrients content can also be exploited for beneficial use.

\section{Salinity hazard}

One of the most important characteristics of determining the suitability of water for direct irrigation is the relative proportion of sodium to other principal cations which is termed the salinity hazard. A better measure of sodium hazard for irrigation is known as sodium adsorption ratio SAR which is used to express reactions with the soil. This parameter is computed using equation 1 . All the samples are found to be less than 10 for both groups and are classified as excellent for irrigation. Figure. 3.2 presents a graphical representation of SAR. This is generated by plotting the specific conductance and SAR values on the US salinity diagram (USSL). When the specific conductance and SAR are known, the classification of irrigation water can be graphically determined by plotting these values on the US salinity diagram. From the results obtained, only 3 samples from In-house sources and 26 samples from outside source were found to be unsuitable for irrigation. However, the remaining samples were all within the doubtful class. Low sodium water can be used for irrigation on most soils with little danger of developing harmful levels of exchangeable sodium while medium sodium is not suitable for fine textured soils but can be safely applied to coarse soils. High and very high sodium water are not suitable for irrigation since they may produce harmful levels of exchangeable sodium and this will lead to soil sodicity which is highly undesirable in irrigation. From the chart, it can be observed that all the samples fall within the sodium hazard class C3S1, C4S1 and C4S2 which is an indication of high to very high salinity. This therefore suggests that greywater within the study area cannot be safely used for irrigation based on the salinity hazard. The (SAR) values obtained in this study (4-11.7) are within than what is reported in a similar study by Katukiza et al. (2014) in Uganda which recorded (4-15). The high SAR values could probably be due to the use of more sodiumbased detergents.

$$
S A R=\frac{\left[\mathrm{Na}^{+}\right]}{\sqrt{\frac{\left(\left[\mathrm{Ca}^{2+}\right]+\left[\mathrm{Mg}^{2+}\right]\right)}{2}}}
$$

Where $\left[\mathrm{Na}^{+}\right],\left[\mathrm{Ca}^{2+}\right]$ and $\left[\mathrm{Mg}^{2+}\right]$ are in $\mathrm{mmolL}^{-1}$ 


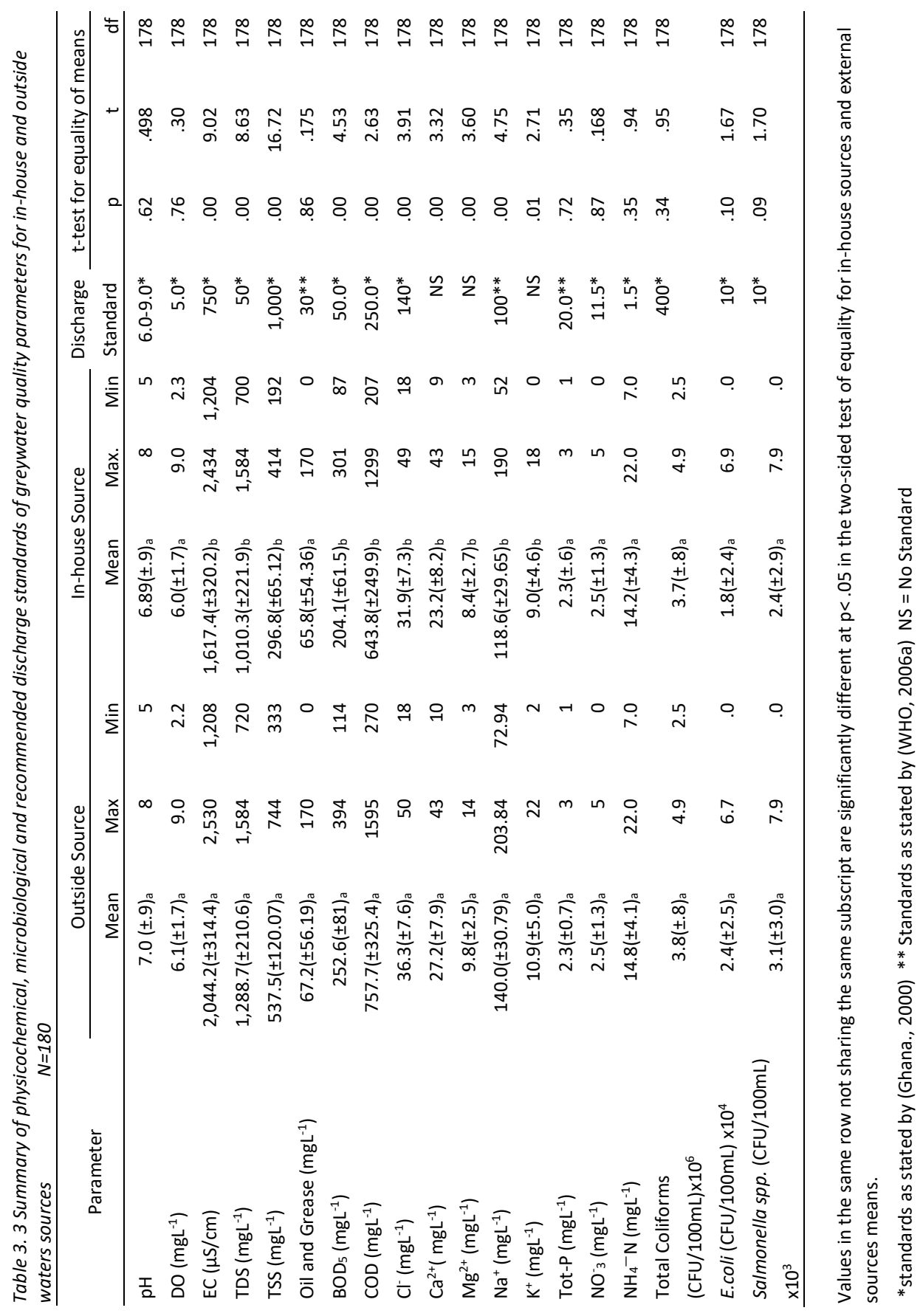




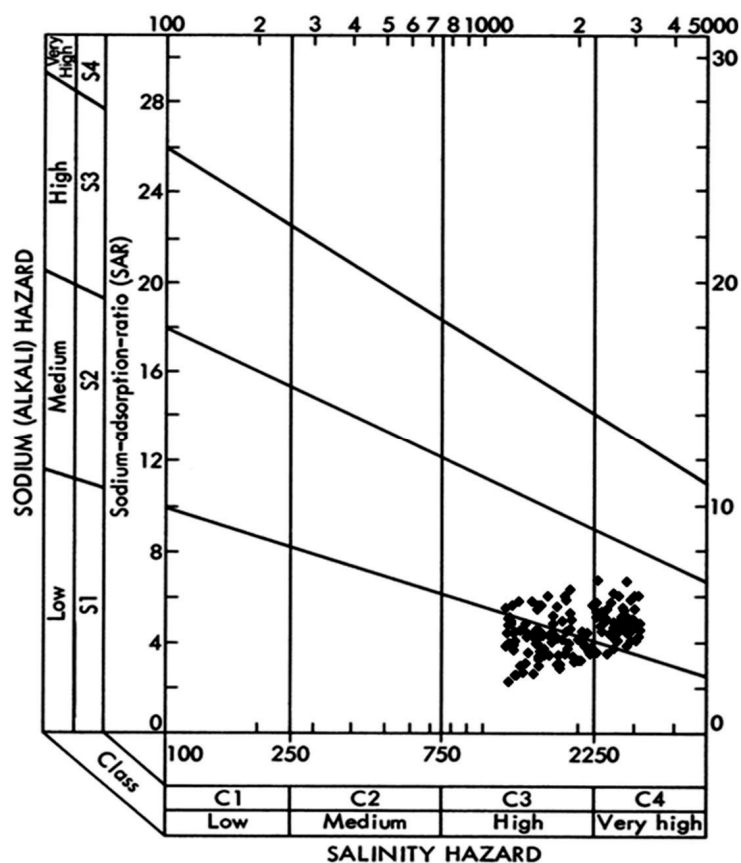

Figure 3. 2 USSL classification of greywater for Irrigation within the study area

\section{Biodegradability potential of greywater}

The potential of biodegradability of greywater is largely based on the $\mathrm{BOD}_{5} / \mathrm{COD}$ ratio. According to Tchobanoglous et al. (2003), a $\mathrm{BOD}_{5}$ to COD ratio close to or above 0.5 is an indication of good biodegradability of the greywater and as such any treatment schemes can rely on microbiological processes. In this study, a $\mathrm{BOD}_{5}$ to $\mathrm{COD}$ ratio for greywater from outside sources ranged between $0.23-$ 0.62 while greywater from in-house sources ranged between $0.22-0.59$. This shows a very wide variability within which to justify the biodegradability of the greywater. About $78 \%$ of the $\mathrm{BOD}_{5}$ to $\mathrm{COD}$ ratios recorded for greywater from outside sources fell below the recommended ratio of 0.5 while about $83 \%$ recorded from in-house sources also fell below the 0.5 ratio. This is an indication that, the greywater analyzed from both sources have low potential for biodegradability. It also supports the assertion that mixed greywater is not easily biodegradable. The results obtained in this study however fall within the range of typical $\mathrm{BOD}_{5}$ to COD ratios reported by Tchobanoglous et al. (2003) of $0.3-0.8$.

\section{Microbiology}

There were significant number of microorganisms in the samples taken from the sampling sites. Total Coliforms, E.coli and Salmonella spp. were detected in $100 \%, 52 \%$ and $48 \%$ respectively out of 180 samples tested. The presence of E.coli is a strong indication of fecal contamination, which is registered in both groups. This could be due to washing of baby's nappies or from ablution. The presence of Salmonella spp. is also a strong indication of fecal contamination. It can also be attributed to washing of meats and other household items which already carry the bacteria. There were no significant differences between 
microorganism loads recorded between outside and in-house sources. This could be an indication of probably equal sanitation lifestyles practiced by both groups. These high concentrations of E.coli and Salmonella spp. in greywater from households pose a health risk to residents. Similar studies conducted by (Alsulaili \& Hamoda, 2015; Birks \& Hills, 2007; Dalahmeh, Lalander, Pell, Vinneras, \& Jonsson, 2016; Sievers, Watzel, Londong, \& Kraft, 2016) also identified these microorganisms in greywater samples. A study by Westrell, Schonning, Stenstrom, and J. (2004) states about $8 \%$ of E.coli and Salmonella spp. are pathogenic hence the occurrence of fecal coliform and Salmonella spp. in greywater indicates a risk of human illness or infection through contact with water. Therefore $10^{2}-10^{6} \mathrm{cfu}\left(100 \mathrm{~mL}^{-1}\right)$ is a clear indication that the greywater is not fit for direct reuse or human contact.

\section{Constituent loading}

In estimating constituent loading, the parameter of interest are the parameters analyzed and the volume of greywater discharged into the environment. It was calculated using equation 2 .

$$
P_{a v . c}=C_{n} Q_{a v . c}
$$

$\mathrm{P}_{\mathrm{avc}}=$ the specific pollutant load generated per capita per day

$C_{n}=$ is the average concentration of parameter $n$ in greywater

$\mathrm{Q}_{\mathrm{av}}=$ is the average greywater generated per capita per day.

The specific pollutant loads calculated for all the parameters indicates that houses with in-house source generate higher loads than outside source. This can be due to the volume of water consumption, which is about twice that of outside source. Some of these values obtained in this study compared with other studies is presented in Table 3.4. However, some studies also showed completely wide variations from this study as also reported in the table below. It was impossible to calculate the overall pollutant load per day due to unavailability of data on numbers who have in-house connection and those without. A relative pollution contribution of in-house and outside sources is shown in figure. 3.3.

Table 3. 4 Pollutant loading from different studies

\begin{tabular}{|c|c|c|c|c|c|c|}
\hline Parameters & $\begin{array}{l}\text { Outside } \\
\text { Source }\end{array}$ & $\begin{array}{l}\text { In-house } \\
\text { source }\end{array}$ & $\begin{array}{l}\text { (Friedler, } \\
2004 \text { ) }\end{array}$ & $\begin{array}{l}\text { (SANDEC, } \\
2006)\end{array}$ & $\begin{array}{l}\text { (Busser et } \\
\text { al., 2006) }\end{array}$ & $\begin{array}{l}\text { (Sievers et } \\
\text { al., 2016) }\end{array}$ \\
\hline TSS $\left(\mathrm{gc}^{-1} \mathrm{~d}^{-1}\right)$ & 17.2 & 22.0 & 29 & $10-30$ & - & - \\
\hline Oil and Grease $\left(\mathrm{gc}^{-1} \mathrm{~d}^{-1}\right)$ & 2.15 & 4.9 & 19 & - & - & - \\
\hline $\mathrm{BOD}_{5}\left(\mathrm{gc}^{-1} \mathrm{~d}^{-1}\right)$ & 8.06 & 15.1 & 23 & $20-50$ & - & - \\
\hline $\operatorname{COD}\left(\mathrm{gc}^{-1} \mathrm{~d}^{-1}\right)$ & 24.24 & 47.6 & 46 & - & $18-37$ & 45 \\
\hline $\mathrm{NH}_{4}\left(\mathrm{gc}^{-1} \mathrm{~d}^{-1}\right)$ & 14.8 & 1.1 & 0.15 & - & - & - \\
\hline $\mathrm{TP}\left(\mathrm{gc}^{-1} \mathrm{~d}^{-1}\right)$ & 0.1 & 0.2 & - & $0.2-6$ & $0.4-0.6$ & 0.4 \\
\hline Salmonella spp. $\left(\mathrm{CFUc}^{-1} \mathrm{~d}^{-1}\right) \times 10^{5}$ & 9.9 & 17.8 & - & - & - & - \\
\hline E.coli $\left(\right.$ CFUc $\left.{ }^{-1} \mathrm{~d}^{-1}\right) \times 10^{6}$ & 7.7 & 13.3 & - & - & - & - \\
\hline Total Coliforms $\left(\right.$ CFUc $\left.^{-1} \mathrm{~d}^{-1}\right) \times 10^{9}$ & 1.2 & 2.7 & - & - & - & - \\
\hline
\end{tabular}




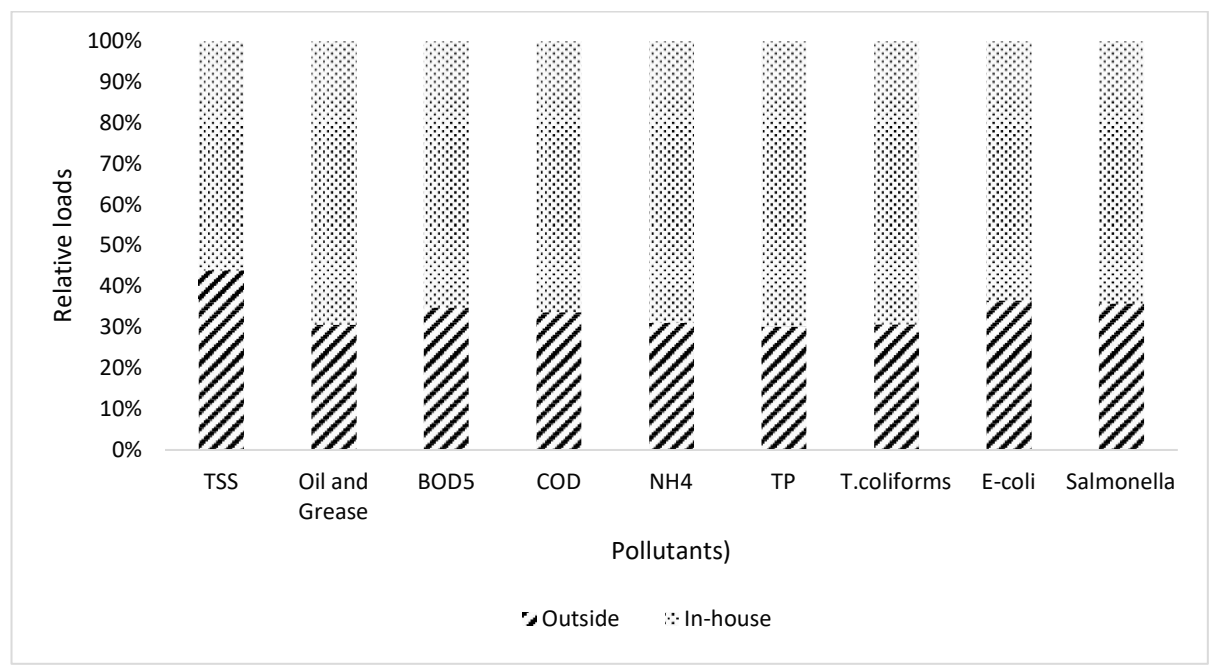

Figure 3. 3 Relative distribution of load between in-house and outside sources

\section{Evaluation of factors influencing greywater quality (Principal Component Analysis)}

A principal component analysis was conducted on 17 out of 19 parameters because two (2) parameters $\mathrm{pH}$, and oil and grease failed the Kaiser-Meyer-Olkin (KMO) test. An oblique rotation (direct oblimin) was used and the $\mathrm{KMO}$ measure verified the sampling adequacy for the analysis, $\mathrm{KMO}=.757$ which is adequate based on the classification of adequacy of KMO by Hutcheson and Sofroniou (1999). All the KMO values for the individual items were greater than 0.5 which is above the acceptable limit as described by Field (2014). An initial analysis was run to obtain eigenvalues for each factor in the data. Five (5) factors had eigenvalues over the Kaiser's criterion of 1 and in combination explained $61.45 \%$ of the variance. The scree plot was unambiguous and showed inflexion that would justify retaining 5 factors. Table 3.5 presents the principal components after rotation. 
Table 3. 5 Coefficients for each variable in the first five principal components

\begin{tabular}{lrrrrr}
\hline Variables & PC1 & PC2 & PC3 & PC4 & PC5 \\
\hline DO $\left(\mathrm{mgL}^{-1}\right)$ & .127 & -.028 & -.039 & -.004 & -.243 \\
$\mathrm{EC}\left(\mu \mathrm{Scm}^{-1}\right)$ & .769 & .127 & -.015 & .394 & .025 \\
$\mathrm{TSS}\left(\mathrm{mgL}^{-1}\right)$ & .309 & .083 & .273 & .438 & -.029 \\
$\mathrm{TDS}\left(\mathrm{mgL}^{-1}\right)$ & .770 & .122 & -.022 & .381 & .038 \\
$\mathrm{BOD}_{5}\left(\mathrm{mgL}^{-1}\right)$ & -.013 & .075 & .905 & .078 & -.044 \\
$\mathrm{COD}\left(\mathrm{mgL}^{-1}\right)$ & .016 & -.022 & .899 & -.074 & -.024 \\
$\mathrm{Cl}^{-}\left(\mathrm{mgL}^{-1}\right)$ & .851 & -.056 & .069 & -.161 & .021 \\
$\mathrm{Ca}^{2+}\left(\mathrm{mgL}^{-1}\right)$ & .725 & -.213 & -.028 & -.221 & -.032 \\
$\mathrm{Mg}^{2+}\left(\mathrm{mgL}^{-1}\right)$ & .773 & .023 & .090 & -.163 & .063 \\
$\mathrm{Na}^{+}\left(\mathrm{mgL}^{-1}\right)$ & .833 & .016 & .015 & -.050 & .086 \\
$\mathrm{~K}^{+}\left(\mathrm{mgL}^{-1}\right)$ & .529 & .057 & .024 & .090 & -.238 \\
$\mathrm{TP}^{\left(\mathrm{mgL}^{-1}\right)}$ & -.035 & .117 & .085 & .127 & -.575 \\
$\mathrm{NO}_{3}-\mathrm{N}\left(\mathrm{mgL}^{-1}\right)$ & -.179 & -.178 & -.057 & .735 & .007 \\
$\mathrm{NH}_{4}-\mathrm{N}\left(\mathrm{mgL}^{-1}\right)$ & .125 & .157 & -.157 & .194 & .666 \\
Total Coliforms & .081 & -.131 & .337 & -.049 & .505 \\
E.coli & -.064 & .929 & .095 & -.092 & .013 \\
Salmonella spp. & .015 & .928 & -.060 & -.129 & -.009 \\
& & & & & \\
Eigen Values & 4.58 & 1.90 & 1.67 & 1.16 & 1.14 \\
\% Variance explained & 26.93 & 11.20 & 9.82 & 6.80 & 6.70 \\
\% cumulative & 26.93 & 38.13 & 47.95 & 54.75 & 61.45 \\
\hline
\end{tabular}

Principal component 1 explained $26.93 \%$ of the total variance and the variables which most positively contributed to it were $\mathrm{EC}, \mathrm{Cl}^{-}, \mathrm{Ca}^{2+}, \mathrm{Mg}^{2+}, \mathrm{K}$, and TDS. This component shows the importance of certain migratory ions in solution and their impact on greywater quality. The main sources of these variables are cleaning materials and salt. It is possible to state that PC1 represents cooking and cleaning activities. Principal component 2 explained $11.20 \%$ of the total variance and presents a strong contribution by the variables E.coli and Salmonella spp. The main sources of these variables are associated with fecal contamination therefore it is possible that Principal component 2 represents personal hygiene. Principal component 3 explained $9.82 \%$ of the total variance and the variables which most positively contributed to it were $\mathrm{BOD}_{5}$ and $\mathrm{COD}$. The main sources of these variables can be associated with biodegradable and non-biodegradable materials in the greywater. It is therefore justified to state that PC3 represents biodegradability of the greywater. Principal component 4 explained $6.80 \%$ of the total variance and the variables associated with it are Total Suspended Solids and $\mathrm{NO}_{3}-\mathrm{N}$. These could be associated with the frequency of water use before final disposal. It is therefore possible to state that PC4 represent internal recycling activities. Principal component 5 explained $6.70 \%$ of the total variance and the variables associated with this are $\mathrm{NH}_{4}-\mathrm{N}, \mathrm{TP}$ and Total Coliforms. $\mathrm{NH}_{4}-\mathrm{N}$ is a component of urine and TP is a component of detergents. It is possible that this component is associated with sanitary practices in the bathroom. do Couto et al. (2013) also performed PCA on greywater samples and observed three components that explained $72.63 \%$ of the total variability in the samples. These components were source 
of water, biodegradability and faecal contamination which have also been confirmed as being contributing factors in this study.

Long term disposal of untreated greywater can result in increases in soil chemical parameters and may further result in negative soil and human health impacts (Siggins, Burton, Ross, Lowe, \& Horswell, 2016).

\section{Conclusions}

The study concludes that there are significant differences in quantity and quality of greywater between in-house sources and outside sources and this is largely influenced by lifestyle and water use. This is an indication that there is the need for a critical look at the impact of greywater management in peri-urban areas in developing countries. Due to the level of contamination coupled with the practice of irrigation with water from open drains as practiced in most developing countries, public health could be at a great risk. The contaminated greywater can also serve as drinking water for some livestock which stray out of their pens to graze in the open fields and the implications of these cannot be over emphasized. This situation should therefore inform the policy makers in formulating appropriate policies that aim at addressing the impact of untreated greywater discharge into the environment without recourse to treatment. It should also bring to bear the need to start thinking about domestic greywater treatment systems in such areas before the greywater is finally discharged into the environment. 


\section{Chapter six}

Published as

Oteng-Peprah, M., Acheampong, M. A., \& DeVries, N. K. (2019). Predicting greywater reuse for potable and non-potable purposes in a developing country - a theory of planned behaviour approach.

Desalination and Water Treatment, 142, 56-64. doi:10.5004/dwt.2019.23414 


\begin{abstract}
This study was aimed at predicting greywater reuse in a municipality of a developing country using the theory of planned behaviour. It sought to identify the beliefs that influence people's intentions to reuse greywater for potable and non-potable purposes. Residents within the municipality completed a questionnaire designed with the TPB constructs and other demographic data. Results revealed an excellent fit for potable reuse intention and a mediocre fit for non-potable reuse intentions. Attitudes and behavioural control were the constructs that significantly influenced intentions to reuse greywater for both potable and non-potable purposes. Location of the source of water to the respondents and level of education were introduced as background factors. Location of the source of water had no significant direct or indirect influence on intentions to reuse greywater for potable or non-potable purposes. Level of education had a non-significant indirect and direct effect on intentions to reuse greywater for potable but is mediated through attitudes and perceived behavioural control for non-potable reuse intentions. Strategies aimed at promoting greywater reuse should be targeted at a specific reuse option and not a wholesale intervention that is expected to address all reuse interventions.
\end{abstract}

\title{
Keyword
}

Greywater, Reuse, Theory of planned behaviour, Potable, Non-potability 


\section{Introduction}

Water use and demand around the globe have increased rapidly, even at a higher rate than population growth (WHO, 2006b). Due to industrialization and urbanization, most developing countries are using more water than they previously used in order to sustain both standard of living and economic growth. However, these developing countries have to deal with limited access to clean and potable water. Water resource professionals believe reclaiming water after use is an important and underutilized element of sustainable water resources management. Lack of access to clean water has been shown to be directly linked to poor sanitation and hygiene and a decline in economic growth (UNICEF, 2016). Wastewater generated from human activities is not regarded as a byproduct that can be reused but should be discarded. However, greywater which forms part of wastewater can be easily treated for reuse. Greywater is characterized as a high-volume low strength stream that constitutes about $50 \%-80 \%$ of domestic wastewater (DHWA, 2002; Jamrah, Al-Futaisi, Prathapar, Ahmed, \& Al-Harrasi, 2008; Oteng-Peprah et al., 2018). It is considered a very useful resource, which can address the emerging water crisis that the world is expected to face and further reduce the overreliance in treating freshwater for non-potable uses. Water reuse can help improve water conditions in areas with a lot of strain on their water resources. Many states in the United States support the general concept of greywater reuse for non-potable purposes (EPA, 2012). Direct potable reuse (DPR) has also been used in some arid and semi-arid countries. DPR involves the introduction of treated wastewater into the raw water supply system of a drinking water treatment facility or direct injection of this treated water into a potable water supply distribution system (WRF, 2015). There are many technologies that exist today which can treat greywater into drinking water quality standards. However, despite the proof and certainty that the water meets the required standards for consumption, it has seen more resistance and less interest in the population. Currently, the only city that has adopted DPR on a large scale is Windhoek, the capital city of Namibia where highly treated waste water is recycled into a drinking water system that serves close to 250,000 people (Gale, 2017; WRF, 2015). Other agencies and municipalities in the United States have also begun looking at DPR as a viable option.

In the implementation of any project, public perception has been recognized as one of the integral factors in determining the success of the project. Several studies have been conducted to assess public perception towards greywater reuse in different parts of the world using different strategies. These strategies include interviews, questionnaires, focus group discussions, informal discussions and other equally good social surveys (Alhumoud \& Madzikanda, 2010; Bruvold, 1998; Dolnicar \& Schafer, 2009; Dolnieara \& Saunders, 2006; Higgins, Warnken, Sherman, \& Teasdale, 2002; Jeffery, 2001; Marks, 2006). It is however clear that most of these surveys identified clear support for the concept of greywater reuse as an environmentally sustainable method of protecting freshwater resources and pollution prevention. However, Gifford and Nilsson (2014) identified that simply transmitting knowledge is not enough to change lifestyles and behaviour patterns. It is obvious that communities support the concept of water reuse as a means of responsible water resources management to mitigate scarcity and abate pollution. However, internationally, many technically sound schemes have failed because communities have rejected them. Ajzen, Joyce, Sheikh, and Cote (2011) have suggested that there is the need to identify the beliefs people hold towards an issue and how these beliefs affect their intentions and behaviour rather than making sure people have accurate information. Although some researchers have studied the behaviours of recycled water reuse (Hurlimann, Hemphill, McKay, \& Geursen, 2008; Nancarrow, Leviston, Po, Porter, \& Tucker, 2008), little has been known of how people in developing countries make their decisions to accept or reject greywater reuse schemes. 
This research is therefore aimed at providing a deeper understanding of the factors that will influence the perception of individuals in developing country to accept greywater as an alternative source of water by using a social cognitive model known as the Theory of Planned Behaviour (TPB). This study holistically investigates the reasons why people will want to reuse greywater from the cultural, religious, location of current water supply, regulatory and environmental points of view. Developing this kind of knowledge is crucial for creating interventions that aim to promote greywater reuse and further develop a theoretical decision model for policymakers in developing countries.

\section{Analysis of the framework}

According to the theory, human behaviour is guided by three kinds of considerations: beliefs about the likely consequences of the behaviour (behavioural beliefs), beliefs about the normative expectations of others (normative beliefs) and beliefs about the presence of factors that may facilitate or impede performance of the behaviour (control beliefs) (Ajzen, 1991; Fishebein \& Ajzen, 2015). In their respective aggregates, behavioural beliefs produce a favourable or unfavourable attitude towards the behaviour; normative beliefs result in perceived social pressure or subjective norms and control beliefs give rise to perceived behavioural control. In combination, attitude toward the behaviour, subjective norm and perception of behavioural control lead to the formation of a behavioural intention which may then be converted into action. The direct path between perceived behavioural control and behaviour models the actual behavioural control. This refers to the extent to which a person has the skills, resources and other prerequisites needed to perform a given behaviour. Therefore, the successful performance of the behaviour depends not only on favourable intention but also on a sufficient level of behavioural control (Ajzen, 1991). According to the model, people's attitudes toward behaviour are determined by their accessible beliefs about the behaviour, where a belief is defined as the subjective probability that the behaviour will produce a certain outcome. The outcome probability is weighed with the subjective evaluation of the outcome (Ajzen \& Fishebein, 1975). In the theory of planned behaviour, the expectancy values of attitude, subjective norm and perceived behavioural control are obtained by the product of behavioural belief and outcome evaluations, normative belief and motivation to comply and, control belief and perceived power to control respectively. The conceptual framework supporting this theory is presented in figure 6.1.

The defining behaviour of interest in the design of the questionnaire is the individual perception towards greywater reuse thus the flexibility within which an individual is willing to accept greywater as an alternative source of water. Following the definition of the three main determinants, as described in the theory of planned behaviour, the individual determinants of greywater reuse consider the various reuse options that are available for greywater reuse and these are non-potable and potable uses. An individual's societal norms refer to the pressure or level of acceptance for the option of greywater reuse and these include family, neighbours and the regulatory body. The individual's perceived behavioural control refers to the ability of an individual to reuse greywater.

The predictive strength of these factors is analyzed using structural equation modelling (SEM) to examine the relationship between factors and individual perceptions of greywater as an alternative source of water. Fundamentally, SEM is a term for a large set of techniques based on general linear models. It is often used to access hidden factors that contribute significantly to a phenomenon or condition. SEM multivariate technique combines aspects of multiple regression and factor analysis to assess a series of 
dependent relationships simultaneously which is not possible using other multivariate techniques (Hair, Anderson, Tatham, \& Black, 2014).

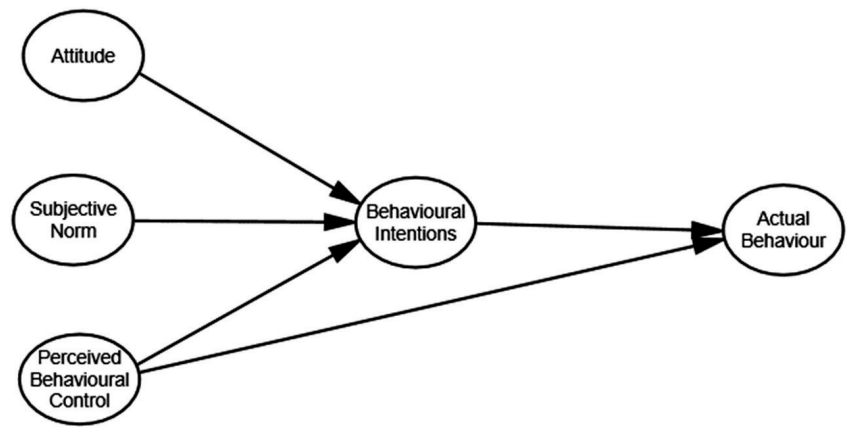

Figure 6. 1

\section{Methodology}

This was a cross-sectional study carried out among local residents of a peri-urban municipality within the central region of Ghana. The central region of Ghana is chosen for this study because it has a blend of rural, peri-urban and urban settlements. It also has people from different cultures and ethnicities. The study adopted a random sampling approach to collect data. The study used the TPB to assess the predictive power of the Theory's constructs on the intention to reuse greywater for potable and nonpotable reuse options.

\section{Pilot study}

Fishebein and Ajzen (2015) suggest elicitation of accessible beliefs from a sample of respondents prior to designing the TPB questionnaire. A pilot study was conducted among 50 local residents within the study area. An open-ended questionnaire was administered to them to determine their readily accessible beliefs about greywater reuse. They were asked to write their opinion about greywater reuse with specific emphasis on the advantages and disadvantages of reusing greywater for domestic potable and other nonpotable uses such as irrigation, toilet flushing, car washing etc. They were also to state the persons or groups of people who would approve or disapprove of their actions in greywater reuse and finally factors that could either facilitate or prevent them from reusing greywater for the above-listed functions. A content analysis of the responses was conducted to determine frequencies of each of these responses and the most frequent responses were included in the model set.

Prior to conducting the main study, 60 local residents were selected for a pretest of the questionnaire. This was conducted to test the coherence, understandability, clarity and psychometric properties of the questionnaire. Modifications were then made to questions that were not clearly worded or sounded ambiguous. Because the study is interested in identifying the determinants of greywater reuse for two specific reuse options, the questionnaire was a two-in-one type that had constructs of the TPB model with each section capturing specific reuse option. An overall Cronbach alpha for potability and non-potability reuse were 0.670 and 0.839 respectively indicating that the scales were all adequate. 


\section{Main study}

Residents within the study area were approached by the investigator and after declaring their willingness to participate in the study, they were asked to sign a consent form and received information regarding the aim of the study. The questionnaire was in two parts; one part included items on demographics while the second part included the TPB constructs. All the items on the TPB section were scored using a 7-point Likert scale. Three research assistants were present to support respondents who had difficulty in responding to the questionnaires.

\section{Questionnaires}

\section{Attitude}

The attitude was measured using behavioural beliefs and their outcome evaluation. The questionnaire had a total of 4 questions that were used to assess the participants' beliefs and 4 outcome evaluations about the consequences of reusing greywater for various reuse options. The questionnaire assessed the individual's advantages and disadvantages of reusing greywater. From the elicitation, the relevant beliefs that were identified are water conservation, environmental protection, reduction in water bills and health concerns.

\section{Subjective norms}

Subjective norm was measured using normative beliefs and motivation to comply. The questionnaire had a total of 3 questions that were related to normative beliefs and 3 questions on accompanying motivation to comply. Participants were asked to rate how specific important people either agreed or disagreed to them reusing greywater and whether this has any influence on their decision to either reuse or not reuse greywater for the various reuse options.

\section{Perceived behavioural control}

Perceived behavioural control was measured using control beliefs and power of control factors. The questionnaire had a total of 5 questions that were related to control beliefs and 5 questions that were related to the matching perceived power to control factor. The questionnaire assessed the ability of the individual to reuse greywater without any hinderances.

\section{Behavioural Intentions}

A total of 3 questions were used to assess the intentions of greywater reuse.

\section{Demographics}

The questionnaire assessed demographic information about the respondents. In total, 5 demographic items were assessed in the questionnaire.

\section{Statistical analyses}

A total of 853 respondents were approached and responses were received from 526 indicating a response rate of $61 \%$. The researchers cancelled questionnaires that had any item vacant. In all, 462 respondents 
completed all items from the survey. The model constructs are analyzed using factor analysis with structural equation modelling using SPSS Amos 23 with Maximum likelihood estimation. The analyses were performed in two steps. First, the original TPB model was tested for both reuse options. Secondly, in order to better understand the role of education and proximity to the source of water played in intentions, these distal variables (proximity to source and level of education) were introduced into the model.

\section{Descriptive analysis of variables}

The research framework consists of three exogenous and one endogenous variable for each of the reuse options. Each construct shows an acceptable Cronbach alpha value of above 0.60 as recommended by Field (2014). A composite variable of each belief was derived by multiplying each belief statement by its corresponding belief evaluation. The model is assessed by using sample size independent fit indices such as root mean square error of approximation (RMSEA), normed fit index (NFI), Tucker-Lewis index (TLI) and comparative fit index (CFI). According to Cangur (2015), the acceptable values of TLI and CFI are 0.90 while values above 0.95 are classified as excellent, and RMSEA values smaller than 0.08 classified as acceptable while values less than 0.06 classified as excellent. The NFI ranges from $0-1$ with 1 being a perfect fit.

\section{Results}

\section{Demographic profile of respondents}

The demographics and other distal factors are presented in table 6.1. The mean age of the respondents was 40 (12.8) years. From the descriptive statistics of the profile of respondents, it can be observed that a majority of the respondents had tertiary education implying their comprehension of the questionnaire administered to them. The majority of these respondents were Christians which also reflects the religious dynamics within the study area. With reference to the source of water, the majority of the respondents relied on potable pipe borne water supplied by the water company with just a minority still relying on unsafe drinking water sources such as streams. Though a majority indicated they relied on a piped network, not all of them have the resource in their house. As can be seen in table 6.1 , about $31.6 \%$ will have to walk or move out of their dwelling to have access to water. A majority of respondents are Akans which is the largest tribe in Ghana. 
Table 6. 1

Demographics

Sex

Female

229

223

Male

Educational Level

No formal education

44

9.7

Basic

75

123

32

178

Religion

Christianity

331

73.2

Islam

101

10

10

2.2

Source of Water

Pipeborne

387

86.6

Stream

6

1.3

Well

59

13.1

Location of source of water

In-house

309

143

68.4

Outside

Tribe

Akan

297

56

45

54

\section{ercentage}

50.7

49.3

16.6

27.2

.1

22.3

2.2

31.6

65.7

12.4

10.0

Northerner

11.9 


\section{Descriptive statistics}

Participants reported weak intentions $(M=2.04, S D=0.10)$, negative attitude $(M=-4.26, S D=13.04)$, low social pressure $(M=2.32, S D=1.28)$ and negative controllability $(M=-3.81, S D=0.73)$ to reuse greywater for potable purposes. However, for non-potable uses, participants reported strong intentions $(M=5.15$, $S D=0.24)$, positive attitude $(M=9.37, S D=5.81)$, moderately high social pressure $(M=4.54, S D=3.59)$ and high controllability $(M=12.43, S D=0.64)$. The correlation matrix presented in table 6.2 indicates that almost all the variables in the TPB are significantly associated with behavioural intentions. The results showed that the significant predictors of greywater reuse intentions were attitudes and perceived behavioural control while social pressure has no significant influence on intentions to reuse greywater. 


\begin{tabular}{|c|c|c|c|c|c|c|c|c|c|c|c|c|c|c|c|c|c|}
\hline & $\Rightarrow$ & ֻ̊m. & ma & סֶ. & 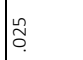 & 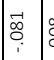 & \begin{tabular}{l|l}
$\infty$ \\
on
\end{tabular} & $\begin{array}{l}q \\
g \\
0\end{array}$ & & 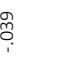 & 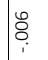 & \begin{tabular}{|l|l|l} 
\\
$\vdots$ \\
0
\end{tabular} & $\stackrel{m}{c}$ & 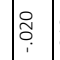 & a & 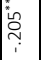 & 4 \\
\hline & 어 & o & 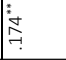 & ָ̦ & 管 & 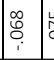 & 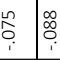 & 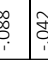 & f & ơ & 诘 & 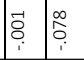 & fo & $\hat{\tilde{o}}$ & సี. & 4 & 茾 \\
\hline & ^) & 员. & : & 岗 & o̊ & 它 & $\vec{a}$ & 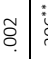 & : & : & i & 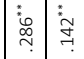 & 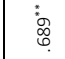 & 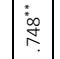 & 4 & $\overrightarrow{8}$ & 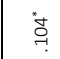 \\
\hline & $\vec{~}$ & $\stackrel{\infty}{\varnothing}$ & fi & পু & 官 & o. & $\overrightarrow{\vec{u}}$ & $\overrightarrow{0}$ & : & ") & ¿ & \begin{tabular}{|l|l} 
\\
$\vdots$ \\
\end{tabular} & 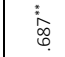 & $\rightarrow$ & 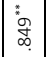 & $\hat{\sigma}$ & تُب \\
\hline & $m$ & 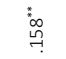 & 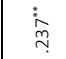 & : & 离 & $\tilde{\Xi}$ & 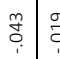 & 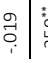 & : & 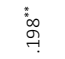 & 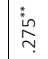 & 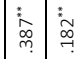 & 4 & 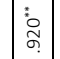 & $\mid$\begin{tabular}{|l|} 
\\
$\vdots$ \\
0 \\
$\infty$
\end{tabular} & 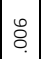 & $\underset{\tilde{z}}{\tilde{Z}}$ \\
\hline & $\approx$ & : & so & ợ & : & : & 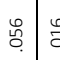 & $\stackrel{0}{0}$ & 焉 & $\stackrel{*}{\stackrel{*}{q}}$ & i & \begin{tabular}{|l|l}
\multirow{i}{*}{} & \\
& -1
\end{tabular} & 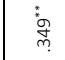 & $\mid \begin{array}{c}\vdots \\
\hat{n} \\
m \\
m\end{array}$ & 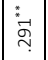 & $\underset{7}{z}$ & $\stackrel{\Pi}{\circ}$ \\
\hline & $\Rightarrow$ & 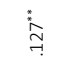 & 車 & $\stackrel{\vdots}{\stackrel{y}{\nearrow}}$ & fo & 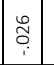 & 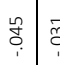 & $\vec{m}$ & 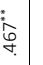 & $\stackrel{\substack{n \\
\infty}}{m}$ & : & 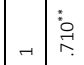 & 苂 & 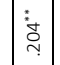 & 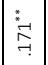 & 总 & $\stackrel{̃}{a}$ \\
\hline$\stackrel{x}{=}$ & 인 & $\stackrel{\infty}{\$}$ & $\hat{\sigma}$ & $\begin{array}{l}0 \\
\stackrel{o}{0}\end{array}$ & $\vec{i}$ & ס̊. & s. & 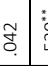 & 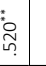 & 苂 & 4 & 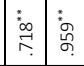 & 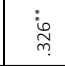 & $\begin{array}{l}\vdots \\
\tilde{m} \\
m\end{array}$ & $\begin{array}{l}\infty \\
\infty \\
\sim \\
\end{array}$ & 妾 & $\tilde{\Xi}$ \\
\hline 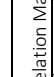 & $\sigma$ & $\overrightarrow{\tilde{D}}$ & aे & $\stackrel{\infty}{0}$ & $\stackrel{\leftrightarrow}{0}$ & : & $\stackrel{9}{0}$ & $\vec{c}$ & 守 & - & 年 & 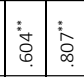 & $\begin{array}{l}\vdots \\
b \\
m \\
m\end{array}$ & 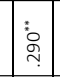 & : & 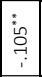 & 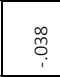 \\
\hline 㤐 & $\infty$ & $\vec{\rho}$ & $\stackrel{\infty}{\infty}$ & : & $\stackrel{\infty}{\circ}$ & $\begin{array}{l}0 \\
0 \\
0 \\
0\end{array}$ & $\begin{array}{c}\overrightarrow{0} \\
0 \\
i\end{array}$ & ¿. & -1 & 8 & : & 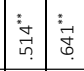 & 总 & $\begin{array}{l}: \\
\vdots \\
m \\
m\end{array}$ & 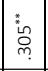 & is & ô \\
\hline & $\wedge$ & $\stackrel{0}{\stackrel{0}{\circ}}$ & $\stackrel{\infty}{\Rightarrow}$ & : & $\stackrel{\infty}{\infty}$ & : & | & $\rightarrow$ & o̊. & 号 & के & \begin{tabular}{|l|l}
0 & $\infty$ \\
8 & 0 \\
\end{tabular} & 客 & ") & $\hat{a}$ & 离 & $\stackrel{\infty}{\circ}$ \\
\hline & 0 & 岗 & fै & ஜֶ̊ & $\stackrel{n}{a}$ & 旁 & 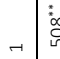 & 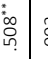 & ธุ. & ơ & $a_{0}^{m}$ & 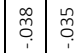 & 市 & $\overrightarrow{\mid r}$ & $\begin{array}{l}0 \\
\text { ong } \\
\end{array}$ & o. & $\stackrel{\widetilde{\vartheta}}{\sigma}$ \\
\hline & in & لْ & 咅 & : & $\stackrel{\circ}{\circ}$ & $\rightarrow$ & 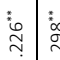 & 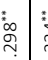 & 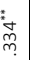 & స్తָ & 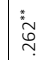 & 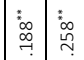 & : & : & 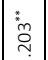 & 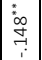 & 离 \\
\hline & $\diamond$ & 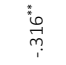 & ڤ્ּ & 䀡 & ${ }_{-}$ & \begin{tabular}{|l|} 
\\
0 \\
$o$ \\
$i$ \\
$i$
\end{tabular} & 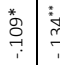 & 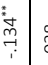 & $\begin{array}{l}\infty \\
\varnothing \\
\varnothing\end{array}$ & 吕 & 声 & $\vec{c}$ & $\begin{array}{l}\infty \\
7 \\
7\end{array}$ & 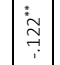 & 韋 & 崖 & ธี \\
\hline & $m$ & 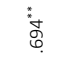 & : & $\rightarrow$ & 竎 & 总 & $\begin{array}{lll}\overrightarrow{0} & \infty \\
i & \infty\end{array}$ & 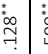 & 萬 & 苔 & ç & 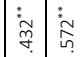 & 官 & 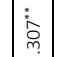 & 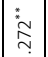 & 茪 & 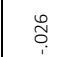 \\
\hline & $\sim$ & 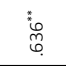 & H & $\stackrel{:}{\stackrel{2}{尺}}$ & ס্⿳亠丷厂巾 & \begin{tabular}{|c|} 
\\
$\dot{m}$ \\
$m$ \\
$m$
\end{tabular} & 苋 & $\vec{H}$ & 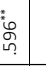 & in & 荌 & 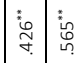 & in & 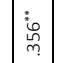 & 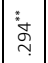 & 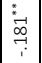 & $\stackrel{\infty}{0}$ \\
\hline & $\rightarrow$ & - & 先 & 苏 & s̆ & : & $\begin{array}{c}m \\
0 \\
i \\
i\end{array}$ & 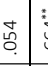 & 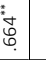 & 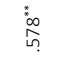 & 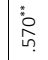 & 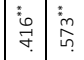 & "ूog & 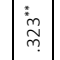 & $\mid \begin{array}{c}: \\
\stackrel{n}{\sim} \\
\sim\end{array}$ & iूn & $\stackrel{\infty}{0}$ \\
\hline 范 & \begin{tabular}{|l|} 
\\
$\vdots$ \\
$\grave{2}$ \\
$\dot{z}$
\end{tabular} & 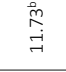 & $\begin{array}{l}\stackrel{\infty}{0} \\
\underset{y}{\exists}\end{array}$ & $\begin{array}{l}\stackrel{\infty}{\infty} \\
\stackrel{్}{\exists}\end{array}$ & 染 & $\begin{array}{l}\stackrel{\circ}{7} \\
\rightarrow \\
-\end{array}$ & 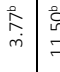 & 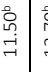 & 总 & 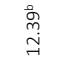 & 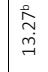 & 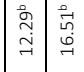 & 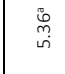 & \begin{tabular}{|l|}
$\vec{\sim}$ \\
$\vec{\sim}$ \\
$i$
\end{tabular} & 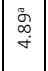 & & \\
\hline$\Sigma$ & 。 & 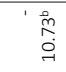 & ' & 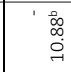 & 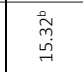 & 惫 & 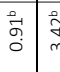 & 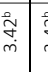 & $\begin{array}{l}\vec{q} \\
\tilde{m} \\
\dot{r}\end{array}$ & 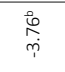 & 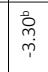 & 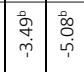 & $\begin{array}{l}\stackrel{\sigma}{\sigma} \\
\stackrel{\sigma}{-}\end{array}$ & & 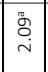 & & \\
\hline & & 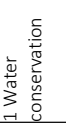 & 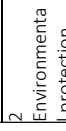 & 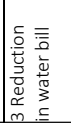 & 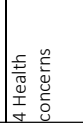 & 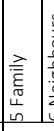 & 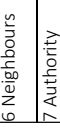 & 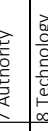 & & 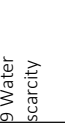 & 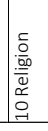 & 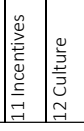 & 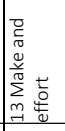 & 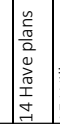 & 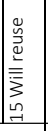 & 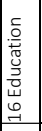 & 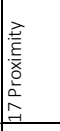 \\
\hline & \begin{tabular}{|l}
$\overrightarrow{0}$ \\
$\vdots$ \\
$z$ \\
$z$
\end{tabular} & 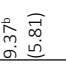 & & & & 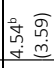 & & & 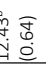 & & & & 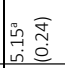 & & & & \\
\hline 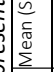 & . & 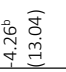 & & & & 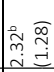 & & & to & & & & 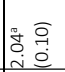 & & & & \\
\hline 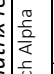 & \begin{tabular}{|c|} 
\\
$\vdots$ \\
0 \\
$z$ \\
\end{tabular} & $\begin{array}{l}\stackrel{2}{0} \\
0 \\
0\end{array}$ & & & & . & & g & & & & & 公 & & & & \\
\hline \begin{tabular}{|l|}
\multirow{2}{0}{} \\
竧 \\
\end{tabular} & 。 & . & & & & 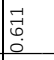 & & รั & th & & & & $\mid$ & & & & \\
\hline 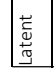 & & & & & әрпт!пн & & 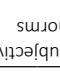 & & & Jennọn & ечәә & 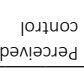 & & suolpue & & & 总总 \\
\hline
\end{tabular}




\section{Testing the TPB model}

The structural models representing potable reuses and non-potable reuses are presented in figure 6.2 and 6.3 respectively. The test indicates that this model accounted for $16 \%$ and $18 \%$ of the total variance in respondent's intentions to reuse greywater for potable and non-potable purposes respectively. Based on the Cohen (2013) classification it can be seen that Attitude $(\beta=0.11, S E=0.008, p=0.039)$ had a small but significant effect on intentions for potable reuse whereas there was a moderate and significant effect of Attitude $(\beta=0.28, S E=0.017, p<0.01)$ on intentions towards non-potable reuse. Both subjective norms had small size effect and were insignificant on intentions for potable reuses $(\beta=0.00, S E=0.014, p=0.996)$ and non-potable reuses $(\beta=0.10, S E=0.019, p=0.056)$. Perceived behavioural control $(\beta=0.37, S E=0.027$, $p<0.01$ ) had a moderate but significant effect on intentions towards potable reuses whereas the effect was weak but significant $(\beta=0.37, \mathrm{SE}=009, p<0.001)$ towards non-potable reuses.

The direct links between composite beliefs and the TPB latent variables were all between $(\beta=0.40-0.98$, $p<0.01$ ) indicating very high effects on the individual latent variables on both potable and non-potable uses. However, there is an insignificant small effect between attitude and health concerns belief composite $(\beta=0.03, p=0.281$ ). Effects between latent variables indicate significant paths for both categories with the strongest effect being between perceived behavioural control and attitude in nonpotable reuse $(\beta=0.68, S E=0.062, p<0.001)$ and between attitude and subjective norm $(\beta=-0.19, S E=0.011$, $p<0.001)$ for potable reuse. The remaining paths show small and insignificant effects $(\beta=0.02-0.17$, $p>0.05$ ).

The fit indices indicate that the standard TPB model provided an excellent fit to the data on potable reuses ( $\mathrm{CFI}=0.963, \mathrm{NFI}=0.929, \mathrm{TLI}=0.954, \mathrm{RMSEA}=0.047)$ and a mediocre fit for non-potable reuses (CFI=0.939, $\mathrm{NFI}=0.925, \mathrm{TLI}=0.924, \mathrm{RMSEA}=0.092)$. 


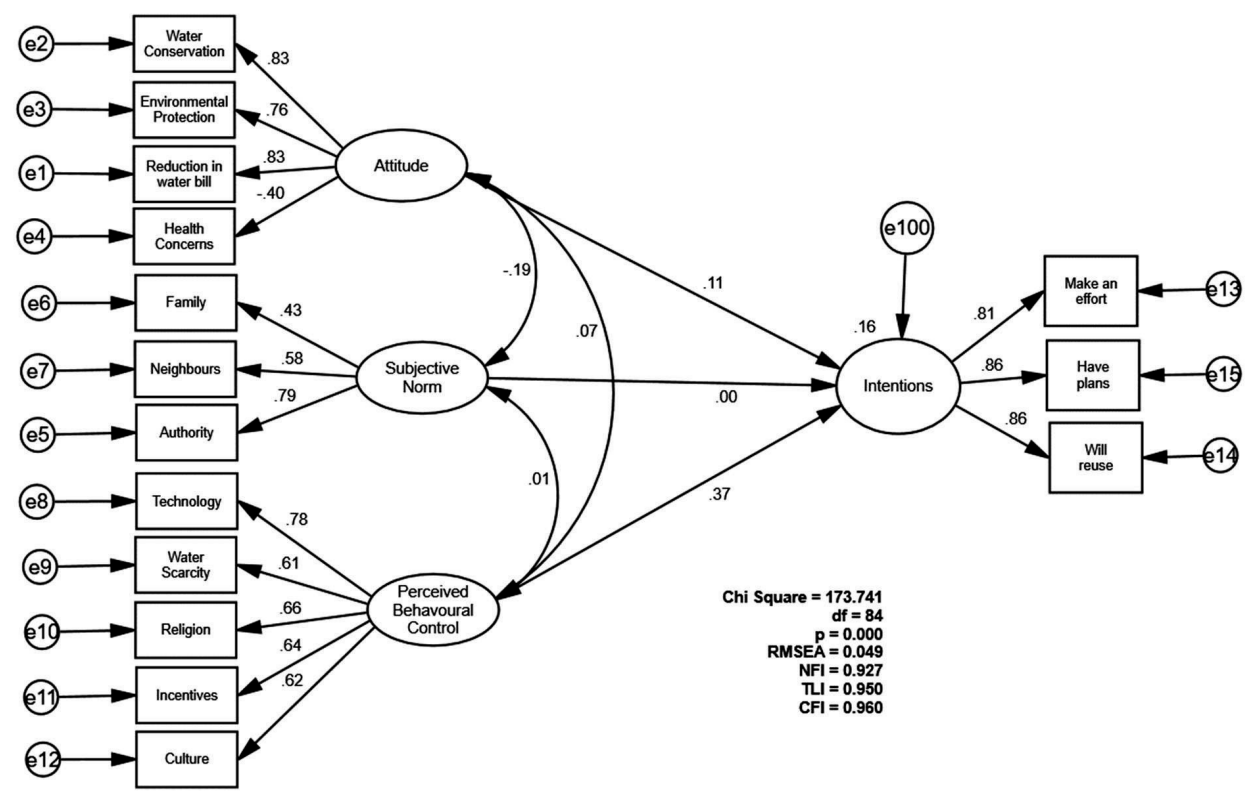

Figure 6. 2 Potability

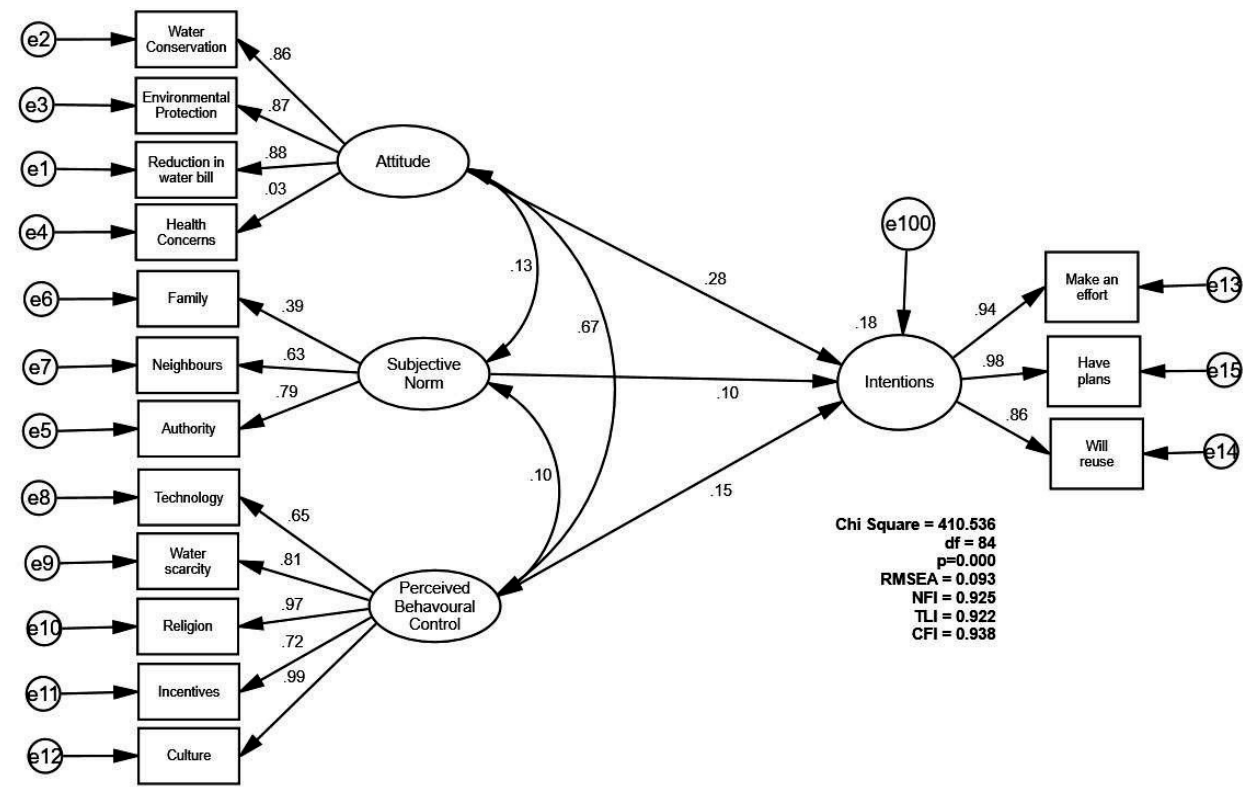

Figure 6. 3 Non-potability 


\section{Effects of beliefs}

The four behavioural beliefs explained $80.4 \%$ of the variance in attitude towards greywater reuse towards both potable and non-potable purposes. These beliefs were 'reusing greywater for potable/non-potable purposes will help me save water at home', 'reusing greywater for potable/non-potable purposes will help me protect the environment', 'reusing treated greywater at home for potable/non-potable purposes will help me reduce my water bills' and 'reusing treated greywater at home for potable/non-potable purposes will be dangerous to my health'. The effect of these beliefs on potable reuses is water conservation $(\beta=0.83, p<0.001)$, environmental protection $(\beta=0.76, p<0.001)$, reduction in water bill $(\beta=0.83, p<0.001)$ and health concerns $(\beta=0.40, p<0.001)$. Whereas the effects on non-potable reuses are: water conservation $(\beta=0.86, p<0.001)$, environmental protection $(\beta=0.87, p<0.001)$, reduction in water bill $(\beta=0.88, p<0.001)$ and health concerns $(\beta=0.03, p=0.281)$.

Five composite control beliefs explained $79.7 \%$ of the variance in perceived behavioural control towards potable reuse and $92 \%$ towards non-potable reuses. These beliefs were: 'an appropriate technology for treating greywater will encourage me to reuse it for potable/non-potable purposes', 'water scarcity will force me to reuse treated greywater for potable/non-potable purposes', 'my religious practices does not prevent me from reusing treated greywater for potable/non-potable purposes', 'incentives for reusing treated greywater potable/non-potable purposes will encourage me to adopt it', 'my cultural practices does not prevent me from reusing treated greywater for potable/non-potable purposes'. The effect of these beliefs on potable reuses are: technology $(\beta=0.78, p<0.001)$, water scarcity $(\beta=0.61, p<0.001)$, religion ( $\beta=0.66, p<0.001)$, incentives $(\beta=0.64, p<0.001)$ and cultural practices $(\beta=0.62, p<0.001)$. Whereas the effects on non-potable reuses are: technology $(\beta=0.62, p=0.001)$, water scarcity $(\beta=0.81, p<0.001)$, religion $(\beta=0.97, p<0.001)$, incentives $(\beta=0.72, p<0.001)$ and cultural practices $(\beta=0.99, p<0.001)$. Subjective norm was not significant in the model hence the effects of individual beliefs on this latent variable were not examined.

\section{Effects of level of education and proximity to the water source}

Level of education and proximity to a source of water were introduced as distal factors into the TPB model as shown in figure 6.4. To avoid overloading the figure, only significant paths have been displayed in the figure. The model provided an excellent fit for potable reuses (RMSEA $=0.050, \mathrm{NFI}=0.922, \mathrm{TLI}=0.933$, $\mathrm{CFI}=0.956$ ) and a mediocre fit for non-potable reuses (RMSEA=0.091, NFI=0.923, TLI=0.904, CFI=0.937). Level of education and proximity to a source of water had neither direct nor indirect significant effects on intentions to reuse greywater for potable purposes. For non-potable purposes, there was no significant direct effect of level of education and proximity to source on intentions, however level of education had a significant direct effect on all five factors of perceived behavioural control: technology $(\beta=-.158$, $\mathrm{SE}=0.244, p<0.01)$ water scarcity $(\beta=-0.125, \mathrm{SE}=0.219, p<0.01)$, Religion $(\beta=-0.154, \mathrm{SE}=0.231, p<0.01)$, Incentives $(\beta=-0.106, S E=0.213, p=0.026)$ and Culture $(\beta=-0.155, S E=0.228, p<0.01)$ and all four factors of attitude: water conservation $(\beta=-0.118, \mathrm{SE}=0.261, p=0.012)$, environmental protection $(\beta=-0.203$, $S E=0.247, p<0.001)$, reduction in water bill $(\beta=-0.165, S E=0.255, p<0.001)$, health concerns $(\beta=0.095$, $\mathrm{SE}=0.258, \mathrm{p}=0.047)$. 


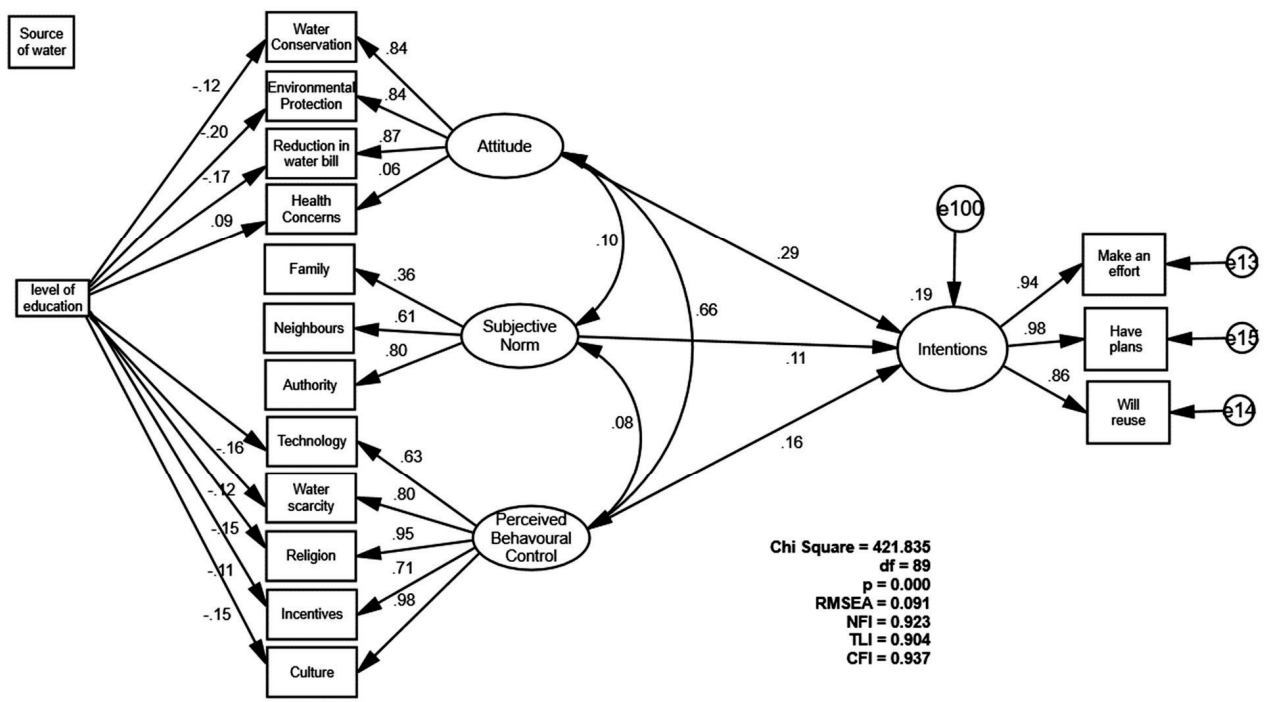

Figure 6. 4 Effect of education on non-potable uses

\section{Discussion}

The results of this study confirm to a large extent that the TPB as a framework can be used to understand greywater reuse in developing countries. Attitudes and behavioural controls accounted for the proportion of variance in intentions to reuse greywater for both potable and non-potable purposes. The use of structural equation modelling revealed an excellent fit for potable reuses and a mediocre fit for nonpotable reuses between the standard TPB model and the data. A scrutiny of the specific behavioural and control beliefs that impacted the overall reuse options among the respondents revealed four behavioural beliefs (Water conservation, environmental protection, reduction in water bill and health concerns) and five control beliefs (technology, water scarcity, religion, incentives and culture).

With reference to the behavioural beliefs, it was realized that water conservation, environmental protection, reduction in water bill and health concerns were all significantly impacting on intentions to reuse greywater and this is also supported in another study (Hurlimann et al., 2008). However, health concerns were not significantly related to the intention to non-potable reuses. With respect to potable reuses, it was realized that participants had a very negative attitude towards this reuse application and this is also supported in a similar study (Marks, 2004). The application of potable water is mostly for consumptive purposes, therefore, use of recycled water can be seen as a health risk and this is supported by the study which identified a very high positive evaluation of good health thus, substituting piped water for recycled water may be seen as a potential health risk. Even though substituting piped water with recycled water can lead to some water reduction, the perceived health risk associated with reusing treated greywater for potable purposes far outweighs its environmental, economic and water conservation benefits. On the other hand, participants had a very positive attitude towards non-potable applications and this could also be due to the volume and uses of water for non-potable applications. Large volumes of water are needed for non-potable applications such as watering of lawns, scrubbing among many others. Since most of these water uses are not for consumptive purposes, there is a clear 
support for accepting a substitute as seen in this study. The study also showed only a very weak perceived health risk associated with this type of use. This suggests that interventions aimed at promoting greywater reuse should consider different approaches since a single approach might not yield positive outcomes for both reuse options. Interventions emphasizing the positive outcomes of greywater reuse are less likely to be effective in potable reuse applications but may rather be effective in non-potable reuse applications. However, interventions that emphasize the perceived health risk are more likely to be effective in potable reuse applications.

The study found out that subjective norm did not significantly influence greywater reuse intentions. This suggests that the judgement of significant others do not matter much in this domain.

For control beliefs, it was realized that all five factors; Appropriate technology, water scarcity, religious practices, Incentives, and cultural practices had a significant effect on intentions to reuse greywater for both potable and non-portable purposes. The study further revealed that participants showed a strong positive ability towards non-potable reuses but moderately negative control over potable reuses. This suggests that providing the necessary skills or technology may only facilitate non-potable uses but will not influence potable reuses.

Our findings have some limitations that should be mentioned. This is a cross-sectional study and this type of study prevents us from making causal inferences. The second limitation is its reliance on self-reports of greywater reuse intentions. It is possible participants may have misreported, be elusive or biased with some of the questionnaire items in their responses. Finally, the representativeness of participants may be limited given the sampling strategy employed which may have introduced selection bias.

\section{Conclusions}

The study sought to find the determinants of greywater reuse in a developing country by considering the two major reuse applications: potable and non-potable reuses. The study identified attitude and behavioural control as the two main constructs that affect intentions to reuse greywater for both reuse applications. However, one intervention method for both reuse options is not likely to lead to effective outcomes. Interventions are supposed to target a specific reuse option by using the factors outlined in the study. It further concludes that level of education does not have a direct effect on intentions to reuse greywater for non-potable purposes but effects are rather mediated through attitude and behavioural control, also supporting the need for a diverse approach to shaping public opinion. From the discussions above, it is evident that non-potable reuse approaches might be easier to implement and monitor as compared to potable reuses. To achieve potable reuse behaviour, it is imperative to approach it from the perceived health risk point of view and further enhance trust in the ability of the individual. It will also be prudent to assess the determinants of willingness to adopt a technology for greywater treatment at the household levels to achieve household level participation of greywater reuse schemes. 


\section{Chapter seven}

Published as

Oteng-Peprah, M., de Vries, N., \& Acheampong, M. A. (2020). Households' willingness to adopt greywater treatment technologies in a developing country - Exploring a modified theory of planned behaviour (TPB) model including personal norm. J Environ Manage, 254, 109807.

doi:10.1016/j.jenvman.2019.109807 


\begin{abstract}
This study explored willingness of households to adopt a greywater treatment and reuse system using the theory of planned behaviour in its original form and an extended model including personal norms. The study was conducted among 478 household heads in the central region of Ghana. The results indicate the original theory of planned behaviour (TPB) model explained about $44 \%$ of the variance in respondents' intentions to adopt this system and the extended model which includes personal norms explained $58 \%$ of the intentions. The extended model turned out to be the better model to predict willingness to adopt this household greywater and treatment system. The findings of this study shed more light on the role of personal norms in households' willingness to adopt a greywater treatment and reuse system and may inform interventions aimed at promoting such systems.
\end{abstract}

\title{
Keywords
}

Households' willingness, greywater, personal norms, theory of planned behaviour, 


\section{Introduction}

Most developing countries are facing huge challenges with pollution in freshwater bodies caused by domestic greywater discharges. This has been attributed to lack of treatment of the greywater before discharge, lack of sewer networks and non-enforced or non-existent greywater discharge guidelines. It has been estimated that in some developing countries as much as $89 \%$ of domestic water demand is converted into greywater (Hernandez Leal et al., 2010; Oteng-Peprah et al., 2018) which is further discharged into either open drains or haphazardly without treatment. However, lightly polluted greywater can be easily treated and reused. Many studies have been conducted on greywater reuse strategies and all these studies point to the fact that this practice is not only worthwhile, it is also a sustainable way of managing water pollution and its effects on the environment (Alderlieste \& Langeveld, 2005; Chong, 2005; Dallas et al., 2004). However, issues of perceived health risks associated with greywater reuse remains a barrier to this practice. Greywater reuse can be best achieved if there is a central collection system for treatment (Hophmayer-Tokich, 2010); however, this collection system is non-existent in most developing countries which has hitherto aggravated the already complicated situation of greywater management.

Another approach to achieve greywater reuse and further reduce the burden on water resources is to tackle it from the households' point of view. Applicable systems such as membrane bioreactor, sequencing batch reactor, rotating biological contactors exist, however, these are mostly applied on large scale greywater reuse systems (Oteng-Peprah et al., 2018). Household greywater treatment and reuse systems are largely non-existent in many developing countries largely be due to the poor dissemination of greywater reuse practices or lack of household treatment system. Encouraging household treatment and reuse schemes in individual households can improve the sanitation situation of participating households and further reduce contaminants that get discharged into the environment.

The key objective for wastewater reuse is to achieve the appropriate quality for its intended use and its subsequent protection of public health and the environment. This intended use can be directly tied to the end application which prescribes the type of treatment required and this can include aesthetics or user specific requirements. Therefore, water reuse technologies are mostly tailored to a specific purpose so that the treatment objectives can be appropriately set for application purpose, public health and environmental protection while being cost effective (Li et al., 2009; March et al., 2004).

Public health concerns remain one of the key barriers to implementing greywater reuse practices. Many states in the United States, however, support the general idea of greywater reuse for non-potable purposes and this has led to implementation of numerous greywater reuse projects. These projects have demonstrated that use of properly treated reclaimed water is safe for human health and the environment as it has been reported that 'to date, epidemiological analyses of adverse health effects likely to be associated with use of reclaimed water have not identified any patterns from water reuse projects in the United States'(NAS, 2012). Another report which investigated the health impact of reclaimed water on landscape irrigation conclusively states that there have not been any confirmed cases of infectious disease that have been documented in the United States as having been caused by contact, ingestion or inhalation of pathogenic microorganisms at any landscape irrigation site subject to reclaimed water criteria"(USEPA, 2012). The city of Windhoek in Namibia uses recycled water to augment water supplies for potable purposes and has also not reported any public health problems (Haarhoff \& VanderMerwe, 1996; Menge, 2010; Onyango, Leslie, \& Wood, 2014). All these points to the fact that once the necessary technology is put in place, reusing wastewater can be considered a safe and sustainable method of managing our water resources and also reduce the burden on water treatment plants. However, if 
household greywater treatment is to be implemented, there is the need to assess the willingness of households to practice and adopt such a treatment system.

This study adopts a social cognitive model known as the theory of planned behaviour (TPB) in identifying beliefs of heads of households that lead to adoption of a greywater treatment and reuse system. It extends the original TPB model to include personal norms. Personal norms have been demonstrated to be closely related with attitudes and subjective norms by Conner and Armitage (1998). Figures 7.1 and 7.2, shows the default and extended TPB models respectively. Studies by Klockner (2013) have further revealed that personal norms not only contribute to a better explanation of intentions and behaviour, but also improves the predictability of attitudes. Various authors have further argued that especially people's environmental attitude seems to be determined by personal norms (Arvola et al., 2008; Kaiser, 2006). The TPB model has been successfully applied to analyze different pro-environmental behaviors in both its original state and extended forms (Botetzagias, Dima, \& Malesios, 2015; De Leeuw, Valois, Ajzen, \& Schmidt, 2015; Fielding, McDonald, \& Louis, 2008; Ford, Williams, Bishop, \& Webb, 2009; Harland, Staats, \& Wilke, 1999; Peters, Gutscher, \& Scholz, 2011; Quintal, Lee, \& Soutar, 2010; Tonglet, Phillips, \& Bates, 2004; Wauters, Bielders, Poesen, Govers, \& Mathijs, 2010).

The inclusion of additional variables into the TPB model has been theoretically supported by many authors due to the improved explanatory power it derives after the inclusion (Botetzagias et al., 2015; Christian, Armitage, \& Abrams, 2007; Thogersen \& Olander, 2006). However, application of this model to proenvironmental behaviour in developing countries is very limited. Considering the hazard caused by discharging of untreated greywater into the environment in some developing countries such as Ghana, Uganda, Nepal, Mali and lack of treatment facilities as reported by (Alderlieste \& Langeveld, 2005; Katukiza et al., 2014; Oteng-Peprah et al., 2018; Shresta, 1999) it is prudent to explore greywater treatment and reuse at the household levels. Therefore, the purpose of this study is to investigate household's willingness to adopt a greywater treatment and reuse system by first using the theory of planned behaviour in its original state and then extend this model to include personal norms. Knowledge of this will be a stepping stone on which interventions targeted at promoting greywater treatment and reuse at the household level in developing countries can be developed.

\section{Analysis of the framework \\ The theory of planned behaviour}

This theory has shown that people's behaviour in most situations can be explained and predicted by intentions, attitudes, subjective norms and behavioural control. Intention is defined by the theory as a cognitive representation of a person's readiness to perform a given behaviour, and it is considered to be the immediate antecedent of behaviour (Ajzen, 1991). Attitude according to the theory is defined as an individual's positive or negative feeling associated with performing a specific behaviour. It further states that an individual will hold a favorable attitude toward a given behaviour if he/she believes that performing the behaviour will lead to mostly positive outcomes. Therefore, attitude toward a behaviour is a positive or negative evaluation of performing that behaviour. Subjective norm is defined by the theory as the perceived social pressure to engage or not to engage in a behaviour. It is the outcome of how important referent others approve or disapprove a behaviour or intention. Finally, perceived behavioural control refers to people's perception of their ability to perform a given behaviour.

Following the definition of the three main determinants of human planned behaviour (attitude, social pressure, perceived behavioural control), the attitude of the household can be defined as the degree to 
which the household head expects good or bad outcomes from adopting a household greywater treatment and reuse system. The household's social pressure refers to the expectation of others to adopt or develop a greywater reuse and treatment system from important referent people. The household's perceived control focuses on beliefs about how easy or difficulty it will be to adopt or develop a greywater treatment and reuse scheme. Personal norms is defined by Schwartz and Tessler (1972) as expectations that people hold for themselves. This translates into how the household head may perceive the personal norms on the household to contribute to making a change in the environment.

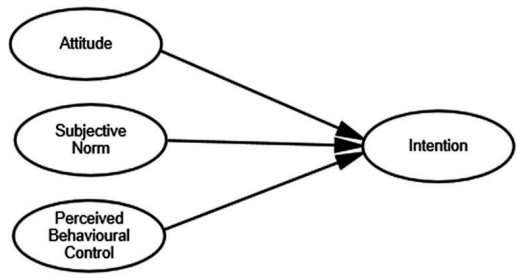

Figure 7. 1 Default TPB model

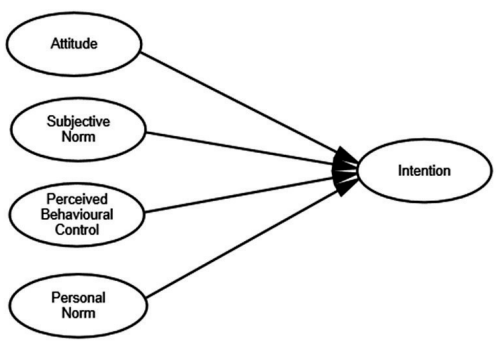

Figure 7. 2 Modified TPB model with personal norm

\section{Questionnaire}

The questionnaire used for this study consisted of two parts; one part included items from the TPB constructs while the other part included demographics. The measurement items were developed from an elicitation study among 25 selected household heads. All the TPB constructs were measured with a 7point Likert scale. The intention to adopt/develop greywater treatment systems was measured with 2 items, attitude measured with 3 items, subjective norms measured with 3 items, perceived behavioural control measured with 4 items and personal norms measured with 3 items. With the exception of intentions and personal norms, belief measurements had corresponding outcome evaluations.

\section{Methodology}

The target group was restricted to the head of the household since they are responsible for making decisions on behalf of the family. About 810 households were surveyed within the central region of Ghana using random sampling method and 521 household heads completed a self-report questionnaire representing a $64 \%$ response rate. Each respondent was introduced to the concept of greywater treatment and the treatment systems. This was done by defining greywater, and pointing to their sources, average per capita generation rates, physical and chemical characteristics and their mode of discharge into the environment. Since greywater is generated by each household, respondent easily identified with these descriptions. The researcher recruited research assistants who received training on how to assist individuals who may not be able to complete the questionnaire. The research cancelled questionnaires which had any items vacant and finally arrived at 478 responses which were used for the analysis. Statistical package for social scientists (SPSS) version 23 and Amos Version 23 were used for analysis. Structural equation modelling (SEM) was utilized to fit the data to the TPB model. SEM is a multivariate technique that combines aspects of regression and factor analysis to assess a series of dependent relationships simultaneously which is not possible using other multivariate techniques (Hair et al., 2014). 


\section{Descriptive analysis of variables}

The model is assessed by using sample size independent fit indices such as root mean square error of approximation (RMSEA), normed fit index (NFI), Tucker-Lewis index (TLI) and comparative fit index (CFI). The acceptable values of TLI and CFI have been pegged at 0.90 while a value of 0.95 and above indicates an excellent fit; RMSEA values between $0.06-0.08$ are classified as acceptable while values less than 0.06 can be classified as excellent fit and finally, the NFI ranges between $0-1$ with 1 being a perfect fit (Cangur, 2015).

\section{Results and discussion \\ Descriptive statistics}

Most of the respondents were male (63.2\%) and had an average age of $45( \pm 8.2)$ years. This is representative of the household heads in Africa and most of the developing countries. In these countries, the eldest adult male culturally is the head of the household and he makes decisions for the household. In terms of level of education, majority of the respondents (43.10\%) had acquired some level of tertiary education hence an indication of comprehension of the questionnaire items. Participants reported moderate intentions $(M=3.78, S D=1.31)$, a moderate positive attitude $(M=8.13, S D=0.90)$, moderate social pressure $(M=9.19, S D=10.44)$, low controllability $(M=5.74, S D=3.39)$ and a slightly high personal norms $(\mathrm{M}=4.99, \mathrm{SD}=0.93)$. The correlation matrix of the latent variables presented in table 7.1 indicates that almost all the variables in the models are significantly associated with intentions.

\section{Testing the default model}

The structural model representing willingness of households to adopt a greywater treatment and reuse system is presented in figure 7.3. The model was able to explain $44 \%$ of the variance of intentions of households to adopt a greywater treatment system. From the structural model, it can be seen that attitude $(\beta=.31, \mathrm{SE}=.014, \mathrm{p}=000)$, subjective norms, $(\beta=.24, \mathrm{SE}=.021, \mathrm{p}=0.019)$ and perceived behavioural control $(\beta=.36, \mathrm{SE}=.016, p=0.000)$ all had moderate intentions by household heads to adopt a greywater treatment and reuse system which were all statistically significant. All items loaded above 0.60 on their assigned factors with the exception of water conservation $(\lambda=0.53)$ and were significantly associated with their specified constructs. The strongest effect on intentions is perceived behavioural control $(\beta=.36)$, followed by attitude $(\beta=0.31)$ and subjective norms $(\beta=.24)$. The fit indices indicate that the standard TPB model provides an excellent fit to the data for the default model $\left(\chi^{2}=110.82, d f=48, p<0.000, N F I=0.935\right.$, $\mathrm{TLI}=0.942, \mathrm{CFI}=0.962, \mathrm{RMSEA}=0.044)$.

\section{Testing the modified model}

The modified structural model with personal norms is presented in figure 7.4. This shows an improvement in prediction over the default model and explained $58 \%$ of the variance in the model. In the modified model, the strongest effect on intentions is personal norms $(\beta=.50)$ followed by perceived behavioural control $(\beta=.30)$, subjective norm $(\beta=.11)$ and attitude $(\beta=.10)$. The modified model also shows an improvement in the fit indices over the default model $\left(\chi^{2}=184.18, d f=80, p<0.001, N F I=0.949, T L I=0.951\right.$, $\mathrm{CFI}=0.970$, RMSEA $=0.041$ ) which is an excellent fit for the data.

Table 6.1 presents the average scores on the determinants of willingness. The willingness is assumed to be based on the rational expectations of the household head, therefore data in table 6.1 represent the household head's expectations on adoption of a greywater treatment and reuse system at the household level. 


\section{Effect of beliefs}

Comparing the three-path coefficient of the default model (figure 7.3), results showed that the impact of beliefs from attitude thus, environmental hazard, pollution prevention and water conservation were the most important factors that affect the intentions of households to adopt a greywater reuse and treatment system. Again, comparing the four-path coefficient of the modified model (figure 7.4), it can be seen that the impact of beliefs from personal norm thus, moral obligation, feeling of guilt and better feeling had the greatest impact on household's willingness to adopt a greywater treatment and reuse system.

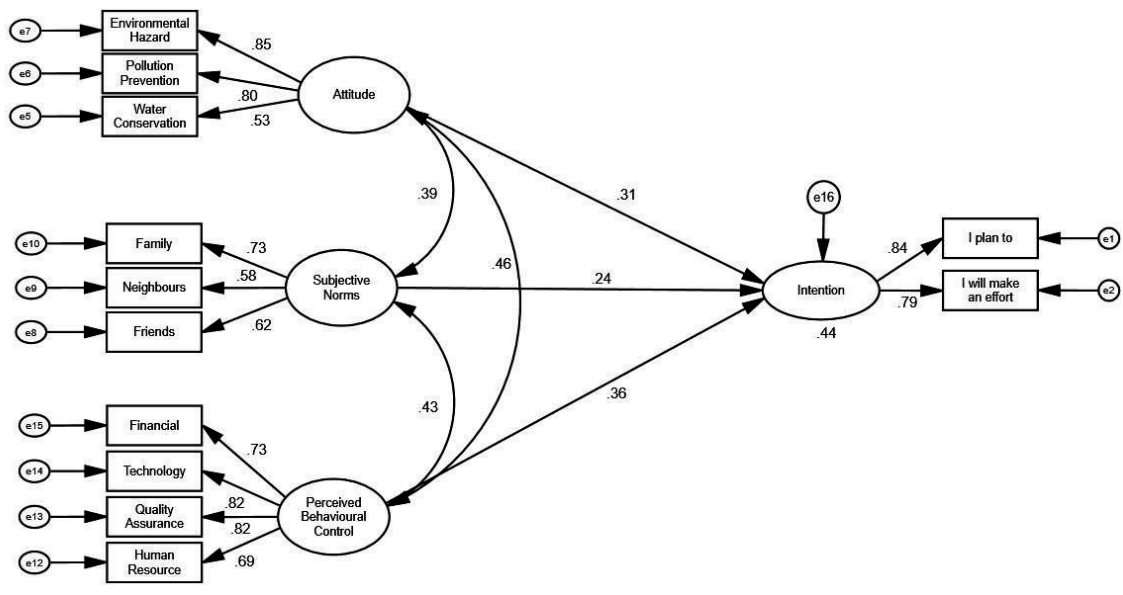

Figure 7. 3 Default model

Table 7. 1

$\begin{array}{llllllll}\begin{array}{l}\text { Cronbach } \\ \text { Alpha }\end{array} & \text { Mean } & \text { S.D. } & 1 & 2 & 3 & 4 & 5 \\ \end{array}$

\begin{tabular}{|c|c|c|c|c|c|c|c|c|c|}
\hline 1. & Attitude $^{1}$ & 0.77 & 8.13 & 0.90 & 1 & & & & \\
\hline 2. & $\begin{array}{l}\text { Subjective } \\
\text { norm }^{1}\end{array}$ & 0.61 & 9.19 & 10.44 & $0.44^{* *}$ & 1 & & & \\
\hline 3. & $\begin{array}{l}\text { Perceived } \\
\text { behavioural } \\
\text { control }^{1}\end{array}$ & 0.65 & 5.74 & 3.39 & 0.24 & 0.23 & 1 & & \\
\hline 4. & Intentions ${ }^{2}$ & 0.84 & 3.78 & 1.31 & $0.50 * *$ & $0.46^{* *}$ & $0.49 * *$ & 1 & \\
\hline 5. & Personal Norm ${ }^{2}$ & 0.75 & 4.99 & 0.93 & $0.59 * *$ & $0.50 * *$ & $0.29 * *$ & $0.69 * *$ & 1 \\
\hline
\end{tabular}

Theoretical range $(-21 \text { to } 21)^{1}(1 \text { to } 7)^{2} \quad{ }^{* *} p<.01$ 


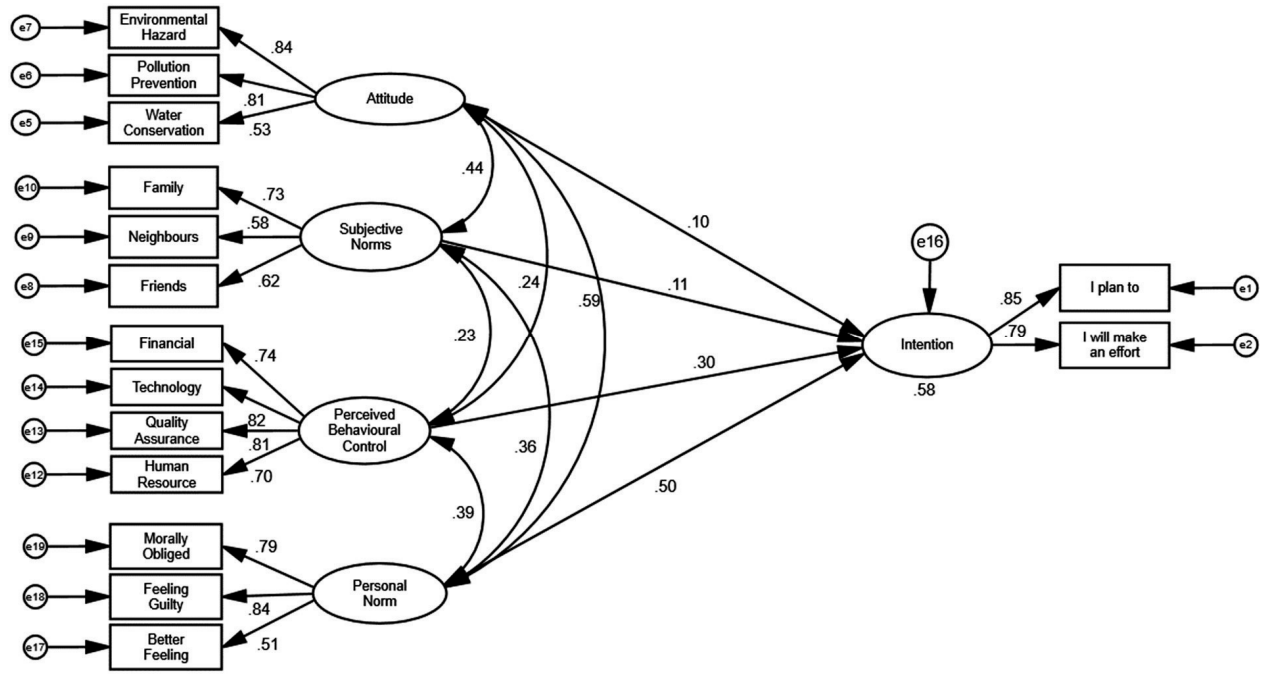

Figure 7. 4 Modified model

\section{Discussion}

To better understand households' intentions to adopt a greywater treatment and reuse system at the household level, two models were tested. The first was the original TPB model and the second an extended TPB model with personal norms. These personal norms are not part of the original TPB model. Greywater treatment and reuse systems are not common in the study area as it is the situation in many developing countries so in this hypothetical case, household heads cannot refer to their past habits and behaviour. Danner, Aarts, and de Vries (2008) suggested that when there is no past behaviour or habits, the future behaviour is guided by intentions. The inclusion of personal norms has been reported to improve the predictive ability of the model especially for pro-environmental behaviours (Arvola et al., 2008; Kaiser, 2006; Klockner, 2013) . The results of the study support the main premise of the original TPB model which says that people who have positive attitude towards the behaviour, receive the support of people who are important to them and think they are able to participate in the behaviour in question will be more likely to carry out that behaviour (Ajzen, 1991). From figure 7.3 it can be seen that attitude, subjective norm and perceived behavioural control are all positively associated with behavioural intentions. The original TPB model explained $44 \%$ of the variance in household's willingness to adopt the greywater treatment and reuse system. When the original model was extended to include personal norm, this increased to $58 \%$ of the variance being explained. The obtained results confirm similar research on pro-environmental behaviour where there was also an increase in the percentage variance explained when the TPB model was extended with personal norms (Harland et al., 1999). The improvement in the model can be associated with better linkage of environmental attitudes with personal norms as suggested by Arvola et al. (2008). The household head's attitude is considered to be a determining factor in adopting this system. The findings of this research further support that the households head perceived attitude has positive impact on the adoption of a treatment system as can be seen in figure 7.3. Generally, for a household to adopt this system it is perceived that it can reduce environmental hazard, prevent environmental pollution and provide economic relief in terms of bills paid for use of water. Social pressure 
has positive and significant impact on households' intentions to adopt this treatment and reuse system. For example, increase in pressure from family members, friends and neighbors that the adoption of this system will reduce environmental hazard, reduce pollution and provide some financial relief will lead to a positive intention towards adopting this system. All four control beliefs: financial incentives, technology, quality assurance and human resource had significant effect on intentions to adopt the treatment and reuse system. For households to adopt this system, they must be able to overcome these factors such as financial commitment into obtaining this system, understand the appropriate technology, have the relevant human resource or expertise available and be assured of the quality assurance of the treated water.

\section{Limitations}

This study used the responses of the household heads and as such it might be possible the responses from the household head may not be the general consensus from members within the household. Again, actual behaviour could not be measured because household greywater treatment and reuse systems are not commonly available in most developing countries, therefore the association between consumers' intention and actual behaviour could not be assessed. Also, most likely, most household heads do not exactly know what a greywater treatment and reuse system might look like - even with the explanation offered in this study and this might also affect the responses to the questionnaire items. The research has only been conducted in the central region of Ghana which makes generalization of the results risky though the social dynamics in the central region can be compared to what prevails in most developing countries. Finally, this is a self-reported questionnaire and hence it might not reflect the true state of the issues as expounded in this questionnaire items.

\section{Conclusions}

The results of this study can be applied by stakeholders and agencies that intend to promote greywater treatment and reuse at the household level in developing countries. In order to convince household heads to adopt household greywater treatment and reuse systems, specific drivers of intentions must be addressed in the campaign. Attitude, personal norms, subjective norm, and perceived behavioural control seemed to all contribute to intentions; however, attitude and personal norms seem to be the strongest determinants. From the viewpoint of attitudes, campaign messages on attitudes could focus on some environmental benefits of greywater treatment and reuse. For example, greywater treatment and reuse systems could prevent environmental hazards and pollution associated with untreated greywater releases and further contribute to conservation of water by adopting a treatment and reuse system. Including these messages in a campaign or intervention message could contribute to attitude change which could then result in actual behaviour. With respect to personal norms, household greywater treatment and reuse systems could be promoted by making it known to households that they could contribute to making a change and that adopting this system could be seen as a moral obligation. This can be done by appealing to households about the hazard associated with release of untreated greywater into the environment without treatment and how this could lead to pollution of freshwater resources and subsequently affect aquatic life and the fact that their adoption of this system can reduce or bring about a change in this environmental hazard. With respect to perceived behavioural control, the treatment system should have a certification of quality and it also should not also affect the finances of the households. In fact, a free system will be easily adopted since it provides no financial burden on households while reducing the volume of treated water that will be paid for. For social norm, household treatment and reuse schemes can be promoted when important others such as family, friends and neighbours have all embraced the concept and fully support this concept. 
Chapter eight

General discussions 
General discussions 


\section{Introduction}

Greywater reuse has been a practice in existence for many years, however, this practice is largely limited to developed countries equipped with the necessary technology and infrastructure. The adoption of this practice into developing countries has been largely non-existent due to numerous reasons. This thesis explores greywater reuse in a developing country by adopting a two-pronged approach. It explores the option of greywater reuse from the technical and social perspective. The technical perspective explores the technicalities viz greywater quality and pollution levels and identifies suitable media for treatment. The thesis used socio-cognitive models to identify factors that are associated with the selection of a particular reuse option. It further explores the willingness of household heads to support the concept of household greywater treatment and reuse schemes. The diversity in the approach used in this dissertation is the key strength in this research. This chapter presents the major findings and discussion points from the entire thesis.

\section{Greywater characteristics}

In order to streamline the research, a comprehensive literature review on greywater reuse, user perception and treatment systems was undertaken. From this comprehensive review (chapter 2), it emerged that there is a wide variation in greywater characteristics and volume generation rates which are mostly associated with lifestyle and type of settlement. It further emerged that most greywater treatment and reuse systems are not applicable at the household levels and this discourages individuals from practicing greywater reuse at the household level especially in developing countries. The review further established the importance of assessing public or user perception in implementing any greywater treatment and reuse schemes. Finally, it was established that in order to develop any greywater treatment and reuse scheme, there is a need to assess the greywater characteristics because this will form the basis on which any treatment or reuse plans will be based upon.

The characteristics of the greywater were studied (chapter 3 ) and the quantity of water used, the return factor and contaminants present were identified. The results of this research conducted with greywater from two main categories (in-house water access and outside source) revealed significant differences in quantity generated and levels of contaminants present. Greywater originating from houses that do not have in-house water connection were much polluted than those originating from houses with in-house water connections. Most of the parameters studied were above the regulatory guideline levels (Ghana., 2000). The study further established that there were huge bacterial loads that were being discharged into the environment. Direct reusage of the greywater for irrigation was identified to be unsuitable to the crop, livestock and soil because it can lead to public health issues and affect soil quality. The study identified hygienic practices, frequency of water use before discharge, detergents used for laundry, and cooking practices, the biodegradability of the greywater as being the main factors that determine the quality of greywater studied within the study area. Though most of the greywater quality parameters were above the regulatory limits, of particular interest in this study were the biochemical oxygen demand $\left(\mathrm{BOD}_{5}\right)$ and chemical oxygen demand (COD) contents because they are mostly the yardstick used to assess the suitability of wastewater before being discharged into the environment (Tchobanoglous et al., 2003). The greywater generated in this study area, therefore, cannot be discharged into the environment without prior treatment. Therefore, regulatory agencies will have to find methods of addressing this issue through both technical and non-technical means. 


\section{Adsorption techniques for BOD and COD removal}

In order to reduce the levels of biochemical oxygen demand (BOD) and chemical oxygen demand (COD) in the greywater using adsorption techniques, activated carbon was prepared from two different locally available agricultural wastes (tropical almond and palm kernel shell). Although there were many agricultural waste materials available for this research, the study used these two materials because of their availability in most tropical regions and because these materials have been regarded as waste materials without any economic value. Again, literature on activated carbon from tropical almond is nonexistent as at the time of this research.

The assessment of the suitability of these materials for their adsorptive capacities constituted an important step in this process. A characterization study was conducted on these two materials for internal surface area (BET), x-ray diffraction (XRD) and scanning electron microscope (SEM). The internal surface area (BET) analysis revealed that palm kernel activated carbon (PKAC) has a higher internal surface area than tropical almond activated carbon (TAAC) suggesting that PKAC has a higher potential to adsorb organic contaminants than TAAC. X-ray diffraction further revealed the entire materials were dominated by carbon and other allotropes of carbon (chapter 4). SEM imagery showed crystalline and distinct shape for the particles of PKAC and large, loose and amorphously shaped particles for TAAC.

It was shown that the effect of particle size was very crucial in the removal efficiency and an optimum average particle size of $2 \mathrm{~mm}$ was obtained for this experiment. Furthermore, the effect of dosage played a key role in the adsorption process and optimum dosage of $6 \mathrm{~g} / \mathrm{l}$ was obtained in the batch experiment.

In order to gain a better understanding of the BOD and COD removal, a batch adsorption experiment was conducted using two common adsorption models; Freundlich and Langmuir adsorption isotherms (chapter 4). To further understand the kinetics involved in this study, the pseudo-first and second-order kinetic models were used. The adsorption data fitted well the Langmuir isotherm being suggestive that the process is more favourable towards adsorption (Belhachemi \& Addoun, 2012; Yan et al., 2015). The kinetic data fitted the pseudo-second order model well with a very high correlation value for both BOD and COD removal from greywater under batch conditions. The value of the adsorption intensity suggests that the adsorption process is very favourable under the conditions studied. From the batch results, it is evident that for maximum removal of BOD and COD from domestic greywater, PKAC performs better than TAAC. The best performing material, PKAC, was used in a fixed bed column studies (chapter 5 ) in order to determine the optimum operating conditions because results obtained in a batch system have mostly been found not to be applicable to what exists in the field (Patel \& Vashi, 2012). The fixed bed system was found to perform better than the batch system achieving as high as $90 \%$ and $86 \%$ removal rates for BOD and COD respectively as compared to the removal efficiency in the batch system.

The fixed bed system was found to perform better at lower feed flowrate and high bed height. At low feed flowrate, the residence time of the greywater in the column is increased allowing for effective adsorption to take place (Sheng et al., 2018). At higher bed depths, there is an increase in the surface area, therefore more available sites for adsorption to take place (Teutscherova et al., 2018). The fixed bed experimental data were fitted to various fixed bed column models and the best performing model identified was the Yoon-nelson (Yoon \& Nelson, 1984) and the BDST models. 


\section{Socio-cognitive models}

From the extensive literature review, it was clear that communities support the concept of water reuse as a means of responsible water resources management to mitigate scarcity and abate pollution. This chapter (6) used the theory of planned behaviour (TPB) (Ajzen, 1991) in its default state to gain a deeper understanding of the factors that will influence an individual in a developing country to accept greywater as an alternative source of water taking into consideration cultural, religious, regulatory and gender perspectives. The results from this study confirmed to a large extent that the TPB framework can be applied in understanding greywater reuse in developing countries.

The study identified a very strong negative intention towards the reuse of greywater for potable purposes but rather showed a good acceptance for reuse for non-potable purposes. Attitudes and behavioural control accounted for a higher proportion of the variance in explaining intentions to reuse greywater. The study revealed that participants showed a strong positive ability towards non-potable reuses but moderately negative control over potable uses which suggests that providing the necessary technology may only facilitate non-potable uses but will not influence potable reuses. Therefore, stakeholders who might want to promote the concept potable greywater reuse must rather channel their efforts at nonpotable reuses. For transfer to potable uses, it was realized that participants had a very negative attitude towards this reuse application as also established in another research (Marks, 2004).

This is closely associated with the perceived health risk associated with using recycled water for consumptive purposes. Although, substituting piped water with recycled water can lead to economic benefits, the perceived health risk associated with this far outweighs this economic benefit and this affects the use of recycled water for potable purposes. The adoption of greywater treatment and reuse system at the household level was explored using the household heads as the focal point (chapter 7). This study used an extended version of the theory of planned behaviour with the inclusion of personal norm (Conner \& Armitage, 1998; Harland et al., 1999). Personal norms was adopted into this study because of the improved explanatory power in pro-environmental behaviour studies and studies that explore willingness (Botetzagias et al., 2015; De Leeuw et al., 2015; Fielding et al., 2008; Klockner, 2013). Although, attitude, personal norms, subjective norms and perceived behavioural control seemed to all contribute to intentions, however, attitude and personal norms seem to be the strongest determinants. This implies that to achieve comprehensive coverage of promoting household greywater and treatment systems, the emphasis should be on factors associated with personal norms and attitudes. For example, campaign messages can be based on the impact caused by discharging untreated greywater into the environment and how recycling and reusing this greywater can contribute to making a change therefore adopting this system could be seen as a moral obligation.

\section{Methodological considerations}

This section describes the methodological approaches used in this dissertation. The study approach, design, strength and limitations are briefly discussed. The approach used in this research may have implications for future research. The study adopted a two-pronged approach to data collection viz laboratory data collection and field instruments. Data for chapters 3, 4 and 5 were obtained through laboratory analysis while data for chapters 6 and 7 were obtained with a scientifically designed research instrument. The diversity in the design of the study is a major strength of this study. The studies were very broad and allowed for the possibilities of many findings on the concept of greywater reuse. This study is 
also based on existing and scientifically proven methodological approaches. For example, greywater sample collection and analysis used protocols from the standard methods for examination of water and wastewater as stated in APHA (2005) (chapters 3, 4 and 5). Chapter 6 used the theory of planned behaviour (Ajzen, 1991) and chapter 7 used an extended form of the theory of planned behaviour which included personal norm (Harland et al., 1999). A very extensive and broad literature review (chapter 2) formed the basis which shaped and supported the theoretical approach used in this study.

\section{Laboratory data}

The data obtained in chapter 3 were from the sampling of different sources using protocols outlined in the APHA (2005). Since the approach used to collect data on water use and wastewater generation for houses that had no water on their compound was a self-report tally card, it could be possible some aspect of the data captured might not reflect what actually exists. The water quality parameters examined in this chapter focused on physicochemical and bacteriological water quality indicators and these parameters were chosen after extensive literature review (chapter 2 ). The data obtained from laboratory analysis was adequate for a detailed characterization of the greywater. Data for chapter 4 and 5 were also obtained from households. In this study real wastewater was used in order to assess the potential of the adsorbent taking into consideration the natural state of the greywater. Due to this, it was not possible to explore the effect of changing the initial concentration of greywater since the same source of greywater was used throughout the experiments. Though there exist many wastewater quality parameters and many of them have been examined in this study, the researchers opted to study the BOD and COD parameters because they represented the organic and inorganic fractions in the greywater.

\section{Field instrument}

In chapters 6 and 7, the data was obtained using a cross-sectional study approach for data collection. The instrument used for data collection was based on the Theory of Planned Behaviour by Ajzen (1991). This explains the intentions of respondents to adopt or reuse greywater. The attitudinal beliefs, referent persons and control beliefs examined in the chapter were obtained through elicitation and from the comprehensive literature review (chapter 2). Chapter 6 collected data from willing respondents while chapter 7 used a targeted approach at collecting data from household heads. Household heads were targeted because they are responsible for decision making within the study area and culturally their decision is binding on the entire household. The study analyzed the data using structural equation modelling (SEM). Due to the cross-sectional nature of these studies, causality could not be explicitly established and thus caution should be exercised when interpreting these findings. Although the researchers made very good efforts at explaining the concept of greywater reuse and treatment to respondents before they participated in the research, however, because the concept of greywater reuse and systems were not available and easily known by respondents, it is possible they may not be able to associate it properly with what the intended purpose of the study is and might lead to misrepresentation in some of the collected data.

\section{Conclusions}

The findings of this research provide insight into fundamental reasons which affect greywater reuse in a developing country and factors that can be used to initiate it. This is important to inform future 
interventions aimed at promoting this practice in developing countries. This practice if embraced will lead to improved sanitation practices and ultimately reduce the environmental pollution associated with the discharge of untreated greywater into the environment. First, the research reveals that the greywater quality indicators are mostly all above the regulatory limits for discharge of water into the environment and ultimately affect freshwater resources. Secondly, it identifies an agricultural waste that has the potential of reducing the organic loads that contribute to BOD and COD to appreciable levels on a batch treatment basis. Thirdly, the research explored the application of this material on a continuous basis using a column and obtained an increase in performance of the continuous removal of BOD and COD. The study further established, through the use of social cognitive models, that advocates for greywater reuse should rather target uses for non-potable applications since there was a very strong negative attitude towards the use of greywater for potable purposes even under very trusted treatment systems. Finally, it established a favourable willingness of households to adopt and begin practicing greywater reuse. It concludes that for advocacy or interventions aimed at initiating greywater treatment and reuse schemes in developing countries, the message should be more centered on personal norms and attitudes; thus the message of such an event should be more tailored at how adopting this practice can help salvage the environment rather than the personal gains they will make from adopting such a system.

\section{Implication for application}

This study has provided a tool for policymakers in developing countries that are faced with water supply issues to rely on for advocacy and planning in trying to address this impact by promoting an alternative source of water supply; greywater reuse. The suitability of the material for reducing organic and inorganic loads in greywater is an indication of its suitability in treating large volumes of greywater into a quality that is reusable for non-potable purposes. This would help improve sanitation practices within waterstressed areas and further improve their economic activities because the time that was previously used to fetch water for non-potable purposes, can be channeled into other productive ventures. It must be emphasized that in implementing this concept, there should not be any financial burdens on the participants since this might lead to the rejection of this concept. There must be available resources that will facilitate this practice and this can be sustained for a while until beneficiaries have accepted this practice and are willing to take it up by themselves. For a comprehensive greywater treatment and reuse scheme to be adopted in Ghana, there is the need for a policy on this concept. This policy document should include building code and plumbing standards for houses that may be interested in adopting this system. It should also contain quality assurance of the treatment system for treating the greywater for reuse. Houses or institutions that adopt this system should also be incentivized as a reward for environmental protection. The lessons learnt in this study can be applicable to other developing countries which share common characteristics and traits with the community studied in this study. It must however be emphasized that, this has been a cross-sectional study and generalizability may not always lead to the same expected outcome.

\section{Further research}

This research has established the suitability of using a locally made adsorbent in reducing the organic and inorganic composition of greywater by adsorption methods. There is the need to design a fully functional domestic greywater treatment and reuse system applying the media as an adsorptive agent and piloted on a small-scale level. There is also the need to explore the regenerative and disposal methods of the 
material after it has been completely used up in order not to also contribute to environmental pollution. It will also be interesting to explore the administrative aspects of this study by studying exploring the economic benefits that will be derived from implementing this concept from the environmental point of view and the personal point of view. Designing of a building code that will address quality issues, monitoring and installing of greywater treatment and reuse schemes will also be an aspect that will require further research. 


\section{References}

Abdel-Shafy, H. I., Al-Sulaiman, A. M., \& Mansour, M. S. (2015). Anaerobic/aerobic treatment of greywater via UASB and MBR for unrestricted reuse. Water Sci Technol, 71(4), 630-637. doi:10.2166/wst.2014.504

Abdulrazak, S., Hussaini, K., \& Sani, H. M. (2017). Evaluation of removal efficiency of heavy metals by low-cost activated carbon prepared from African palm fruit. Applied Water Science, 7(6), 31513155. doi:10.1007/s13201-016-0460-x

Abedin, S. B., \& Rakib, Z. B. (2013). Generation and Quality Analysis of Greywater at Dhaka City. Environmental Research, Engineering and Management, 64(2), 29-41. doi:10.5755/j01.erem.64.2.3992

Acheampong, M. A., Pereira, J. P. C., Meulepas, R. J. W., \& Lens, P. N. L. (2011). Biosorption of Cu(II) onto agricultural materials from tropical regions. Journal of Chemical Technology and Biotechnology, 86, 1184-1194.

Ademiluyi, F. T., Amadi, S. A., Amakama, A., \& Nimisingha, J. (2009). Adsorption and treatment of organic contaminants using activated carbon from waste Nigerian bamboo. J. Appl. Sci. Environ. Manage, 13(3), 39-47.

Adendorff, J., \& Stimie, C. (2005). Food from used water-making the previously impossible happen. Retrieved from

http://journals.co.za/docserver/fulltext/waterb/4/1/waterb v4 n1 a4.pdf?expires=149381121 4\&id=id\&accname=guest\&checksum=510AA057CDF6FD48ADB3BCB40047FFDC

Adewumi, J. R., Olanrewaju, O. O., llemobade, A. A., \& van Zyl, J. E. (2010). Perceptions towards greywater reuse and proposed model for institutional and commercial settlements in South Africa. Paper presented at the WISA Biennial Conference and Exhibitions, South Africa.

Ahmad, A. A., \& Hameed, B. H. (2010). Fixed-bed adsorption of reactive azo dye onto granular activated carbon prepared from waste. Journal of Hazardous Materials, 175(1-3), 298-303. doi:10.1016/j.jhazmat.2009.10.003

Ajzen, I. (1991). The Theory of Planned Behaviour. Organizational Behaviour and Human Decision Processes Vol 50, 179-211.

Ajzen, I., \& Fishebein, M. (1975). A Bayesian analysis of attribution processes. Psychological bulletin, 82(2), 261. doi:10.1037/h0076477

Ajzen, I., Joyce, N., Sheikh, S., \& Cote, N. G. (2011). Knowledge and the Prediction of Behavior: The Role of Information Accuracy in the Theory of Planned Behavior. Basic and Applied Social Psychology, 33(2), 101-117. doi:Pii 937656798

10.1080/01973533.2011.568834

Al-Hamaiedeh, H., \& Bino, M. (2010). Effect of treated grey water reuse in irrigation on soil and plants. Desalination, 256(1-3), 115-119. doi:10.1016/j.desal.2010.02.004

Al-Jayousi, O. R. (2003). Greywater Reuse: Towards sustainable water management. Desalination, 165, 181-192.

Al-Mughalles, M. H., Rahman, R. A., F.B., S., Mahmud, M., \& Jahil, N. A. (2012). Household greywater quantity and quality in Sana'a, Yemen. EJGE, 17, 1025-1034.

Alderlieste, M. C., \& Langeveld, J., G. (2005). Wastewater planning in Djenne, Mali. A pilot project for the local infiltration of domestic wastewater. Water Science and Technology, 51(2), 55-64.

Alderlieste, M. C., \& Langeveld, J. G. (2005). Wastewater planning in Djenne, Mali. A pilot project for the local infiltration of domestic wastewater. Water Sci Technol, 51(2), 57-64. 
Alhumoud, J. M., \& Madzikanda, D. (2010). Public Perceptions on Water Reuse Options: The case of Sulaibiya wastewater treatment plant in Kuwait. International Business and Economics Research Journal Vol 9(1).

Ali, I., Asim, M., \& Khan, T. A. (2012). Low cost adsorbents for the removal of organic pollutants from wastewater. Journal of Environmental Management, 113, 170-183. doi:10.1016/j.jenvman.2012.08.028

Alsulaili, A. D., \& Hamoda, M. F. (2015). Quantification and characterization of greywater from schools. Water Sci Technol, 72(11), 1973-1980. doi:10.2166/wst.2015.408

Alsulaili, A. D., Hamoda, M. F., Al-Jarallah, R., \& Alrukaibi, D. (2017). Treatment and potential reuse of greywater from schools: a pilot study. Water Sci Technol, 75(9-10), 2119-2129. doi:10.2166/wst.2017.088

Aluyor, E. O., Oboh, I. O., \& Obahiagbon, K. O. (2009). Equilibrium sorption isotherm for lead (Pb) ions on hydrogen peroxide modified rice hulls. International Journal of Physical Sciences, 4(8), 423-427.

Amale, P., Kulkarni, S., \& Kulkarni, K. (2014). Studies on packed bed treatment for organic matter in distillery effluent International journal of Engineering Science and Innovative Technology, 3(5), 2014.

Antonopoulou, G., Kirkou, A., \& Stasinakis, A. S. (2013). Quantitative and qualitative greywater characterization in Greek households and investigation of their treatment using physicochemical methods. Sci Total Environ, 454-455, 426-432. doi:10.1016/j.scitotenv.2013.03.045

ANZECC. (2000). National water quality management strategy. Australian and New Zealand guidelines for fresh and marine water quality volume 2. Aukland: Australian Water Association.

Aonghusa, C. N., \& Gray, N. F. (2002). Laundry detergents as a source of heavy metals in Irish domestic wastewater. J Environ Sci Health A Tox Hazard Subst Environ Eng, 37(1), 1-6.

APHA. (2005). Standard methods for the examination of water and wastewater. 21st edition. Washingon: American Public Health Association, American Water Works Association, Water Environmental Federation.

Arvola, A., Vassallo, M., Dean, M., Lampila, P., Saba, A., Lahteenmaki, L., \& Shepherd, R. (2008). Predicting intentions to purchase organic food: The role of affective and moral attitudes in the Theory of Planned Behaviour. Appetite, 50(2-3), 443-454. doi:10.1016/j.appet.2007.09.010

Atanasova, N., Dalmau, M., Comas, J., Poch, M., Rodriguez-Roda, I., \& Buttiglieri, G. (2017). Optimized MBR for greywater reuse systems in hotel facilities. J Environ Manage, 193, 503-511. doi:10.1016/j.jenvman.2017.02.041

Bakker, K. (2012). Water Security: Research Challenges and Opportunities. Science, 337(6097), 914-915. doi:10.1126/science.1226337

Bansode, R. R., Losso, J. N., Marshall, W. E., Rao, R. M., \& Portier, R. J. (2004). Pecan shell-based granular activated carbon for treatment of chemical oxygen demand (COD) in municipal wastewater. Bioresource Technology, 94(2), 129-135. doi:10.1016/j.biortech.2003.12.009

Behnamfard, A., \& Salarirad, M. M. (2009). Equilibrium and kinetic studies on free cyanide adsorption from aqueous solution by activated carbon. Journal of Hazardous Materials, 170(1), 127-133. doi:10.1016/j.jhazmat.2009.04.124

Belhachemi, M., \& Addoun, F. (2012). Adsorption of congo red onto activated carbons having different surface properties: studies of kinetics and adsorption equilibrium. Desalination and Water Treatment, 37(1-3), 122-129. doi:10.5004/dwt.2012.2608

Benami, M., Gillor, O., \& Gross, A. (2015a). The question of pathogen quantification in disinfected graywater. Science of the Total Environment, 506, 496-504. doi:10.1016/j.scitotenv.2014.11.051

Benami, M., Gillor, O., \& Gross, A. (2015b). The question of pathogen quantification in disinfected graywater. Sci Total Environ, 506-507, 496-504. doi:10.1016/j.scitotenv.2014.11.051 
Bhuptawat, H., Folkard, G. K., \& Chaudhari, S. (2007). Innovative physico-chemical treatment of wastewater incorporating Moringa oleifera seed coagulant. Retrieved from http://dspace.library.iitb.ac.in/ispui/bitstream/10054/1654/1/5253-1.pdf

Birgani, P. M., Ranjbar, N., Abdullah, R. C., Wong, K. T., Lee, G., Ibrahim, S., ... Jang, M. (2016). An efficient and economical treatment for batik textile wastewater containing high levels of silicate and organic pollutants using a sequential process of acidification, magnesium oxide, and palm shell-based activated carbon application. Journal of Environmental Management, 184, 229-239. doi:10.1016/j.jenvman.2016.09.066

Birks, R., Colbourne, J., Hills, S., \& Hobson, R. (2004). Microbiological water quality in a large in-building, water recycling facility. Water Sci Technol, 50(2), 165-172.

Birks, R., \& Hills, S. (2007). Characterisation of indicator organisms and pathogens in domestic greywater for recycling. Environ Monit Assess, 129(1-3), 61-69. doi:10.1007/s10661-006-9427-y

Botetzagias, I., Dima, A. F., \& Malesios, C. (2015). Extending the Theory of Planned Behavior in the context of recycling: The role of moral norms and of demographic predictors. Resources conservation and recycling, 95, 58-67. doi:10.1016/j.resconrec.2014.12.004

Boyjoo, Y., Pareek, V. K., \& Ang, M. (2013). A review of greywater characteristics and treatment processes. Water Sci Technol, 67(7), 1403-1424. doi:10.2166/wst.2013.675

Brion-Roby, R., Gagnon, J., Deschenes, J. S., \& Chabot, B. (2018). Development and treatment procedure of arsenic-contaminated water using a new and green chitosan sorbent: kinetic, isotherm, thermodynamic and dynamic studies. Pure and Applied Chemistry, 90(1), 63-77. doi:10.1515/pac-2017-0305

Bruvold, W. H. (1998). Public opinion on water reuse options. Water pollution control federation, 60(1) 45-50.

Bulut, Y., Gozubenli, N., \& Aydin, H. (2007). Equilibrium and kinetics studies for adsorption of direct blue 71 from aqueous solution by wheat shells. Journal of Hazardous Materials, 144(1-2), 300-306. doi:10.1016/j.jhazmat.2006.10.027

Busser, S., Pham, T. N., Morel, A., \& Nguyen, V. A. (2006). Characterisitcs and quantities of domestic wastewater in urban and peri-urban households in Hanoi. Retrieved from http://ir.library.osaka-u.ac.jp/dspace/bitstream/11094/13204/1/arfyjsps2006 395.pdf

Cangur, S. (2015). Comparison of model fit indices used in structural equation modelling under multivariate normality. Journal of Modern Applied Statistical Methods, 14(1), 151-167. doi:10.22237/jmasm/1430453580

Casanova, L. M., Gerba, C. P., \& Karpiscak, M. (2001). Chemical and microbial characterization of household greywater. Journal of environmental science and health Part a Toxic/Hazardour substances and envirnomental engineering 34(4), 395-401.

Chong, B. (2005). Implementation of an urban pilot scale ecological sanitation wastewater treatment system in Kuching Sarawak, Malaysia. Retrieved from Malaysia:

Chowdhury, Z. Z., Zain, S. M., Rashid, A. K., Rafique, R. F., \& Khalid, K. (2013). Breakthrough Curve Analysis for Column Dynamics Sorption of $\mathrm{Mn}$ (II) lons from Wastewater by Using Mangostana garcinia Peel-Based Granular-Activated Carbon. Journal of Chemistry. doi:Artn 959761

$10.1155 / 2013 / 959761$

Christian, J., Armitage, C. J., \& Abrams, D. (2007). Evidence that theory of planned behaviour variables mediate the effects of socio-demographic variables on homeless people's participation in service programmes. Journal of Health Psychology, 12(5), 805-817. doi:10.1177/1359105307080615

Christova-Boal, D., Eden, R. E., \& McFarlane, S. (1996). An investigation into greywater reuse for urban residential properties. Desalination, 106, 391-397. 
Chuck, H. (2004). Composting toilet and greywater system. Retrieved from http://www.aviusa.org/projects usapavilion newsletter may aug 2006.pdf

Ciabatti, I., Cesaro, F., Faralli, L., Fatarella, E., \& Tognotti, F. (2009). Demonstration of a treatment system for purification and reuse of laundry wastewater. Desalination, 245(1-3), 451-459. doi:10.1016/j.desal.2009.02.008

Cohen, J. (2013). Statistical power analysis for the behavioural sciences (Revised edition). New York: Elsevier.

Conjucture, C. (2017). What is Public Perception. Retrieved from http://www.wisegeek.com/what-ispublic-perception.htm

Conner, M., \& Armitage, C. J. (1998). Extending the theory of planned behavior: A review and avenues for further research. Journal of Applied Social Psychology, 28(15), 1429-1464. doi:DOI 10.1111/j.1559-1816.1998.tb01685.x

Crini, G., Badot, P. M., Morin-Crini, N., Jolibois, B., Comte, E., Fahys, B., ... Torri, G. (2008). Flour of corn for dye removal from pulp and paper effluents. Actualite Chimique(325), 8-13.

CSIR, S. A. (2001). Building and construction technology guidelines for human settlement planning and design. Retrieved from Pretoria SA:

Dalahmeh, S. S., Lalander, C., Pell, M., Vinneras, B., \& Jonsson, H. (2016). Quality of greywater treated in biochar filter and risk assessment of gastroenteritis due to household exposure during maintenance and irrigation. J Appl Microbiol, 121(5), 1427-1443. doi:10.1111/jam.13273

Dalahmeh, S. S., Pell, M., Vinneras, B., Hylander, L. D., Oborn, I., \& Jonsson, H. (2012). Efficiency of Bark, Activated Charcoal, Foam and Sand Filters in Reducing Pollutants from Greywater. Water Air and Soil Pollution, 223(7), 3657-3671. doi:10.1007/s11270-012-1139-z

Dallas, S., \& Ho, G. (2005). Subsurface flow reedbeds using alternative media for the treatment of domestic greywater in Monteverde Costa Rica, Central America. Water Science and Technology, 52(10), 119-128.

Dallas, S., Sceffe, B., \& Ho, G. (2004). Reedbeds for greywater treatment-case study in Santa ElenaMonteverde, Costa Rica, Central America. Ecological Engineering, Elsevier, 23(1), 55-61. doi:http://doi.org/10.1016/j.ecoleng.2004.07.002

Danner, U. N., Aarts, H., \& de Vries, N. K. (2008). Habit vs. intention in the prediction of future behaviour: The role of frequency, context stability and mental accessibility of past behaviour. British Journal of Social Psychology, 47, 245-265. doi:10.1348/014466607x230876

De Leeuw, A., Valois, P., Ajzen, I., \& Schmidt, P. (2015). Using the theory of planned behavior to identify key beliefs underlying pro-environmental behavior in high-school students: Implications for educational interventions. Journal of Environmental Psychology, 42, 128-138. doi:10.1016/j.jenvp.2015.03.005

DeSena, N. (2006). Public opposition sidelines indirect potable reuse projects. Water and Environment Technology, 1999, 11-16.

Devi, R., Singh, V., \& Kumar, A. (2008). COD and BOD reduction from coffee processing wastewater using Avacado peel carbon. Bioresource Technology, 99(6), 1853-1860. doi:10.1016/j.biortech.2007.03.039

DHWA. (2002). Draft guidelines for the reuse of greywater in Western Australia. Perth Australia: Department of Health West Australia.

do Couto, E. d. A., Calijuri, M. L., Assemany, P. P., Santiago, A. d. F., \& Carvalho, I. d. C. (2013). Greywater production in airports: Qualitative and quantitative assessment. Resources, Conservation and Recycling, 77, 44-51. doi:10.1016/j.resconrec.2013.05.004

Dolnicar, S., \& Saunders, C. (2006). Recycled water for consumer markets - a marketing research review and agenda. Desalination, 187(203-214). 
Dolnicar, S., \& Schafer, A. I. (2006). Public perception of desalinated versus recycled water in Australia. Paper presented at the AWWA Desalination Symposium, Honolulu, Hawai, United States.

Dolnicar, S., \& Schafer, A. I. (2009). Desalinated versus recycled water: Public perceptions and profiles of the accepters. Journal of Environmental Management Vol 90, 888-900.

Dolnieara, S., \& Saunders, C. (2006). Recycled water for consumer markets - a marketing research review and agenda Vol 187. Desalination, 203-214.

Dwumfour-Asare, B., Adantey, P., Nyarko, K. B., \& Appiah-Effah, E. (2017). Greywater characterization and handling practices among urban households in Ghana: the case of three communities in Kumasi Metropolis. Water Sci Technol, 76(3-4), 813-822. doi:10.2166/wst.2017.229

Eakin, B. W., \& Sharman, G. F. (2010). Volumes of the world's oceans from ETOPO1. Retrieved from https://www.ngdc.noaa.gov/mgg/global/etopo1_ocean volumes.html

Edwin, G. A., Gopalsamy, P., \& Muthu, N. (2014). Characterization of domestic gray water from point source to determine the potential for urban residential reuse: a short review. Applied Water Science, 4(1), 39-49. doi:10.1007/s13201-013-0128-8

Effendi, H., Sari, D. R., \& Hasibuan, S. (2015). Moringa oleifera as coagulant for batik effluent treatment. Paper presented at the 35th Annual Conference of the International Association for Impact Assessment, Firenze Fiera Congress and Exhibition Center Florence, Italy.

Elmitwalli, T. A., \& Otterpohl, R. (2007). Anaerobic biodegradability and treatment of greywater in upflow anaerobic sludge blanket (UASB) reactor. Water Research, 41, 1379-1387.

Elmitwalli, T. A., Shalabi, M., Wendland, C., \& Otterpohl, R. (2007). Grey water treatment in UASB reactor at ambient temperature. Water Sci Technol, 55(7), 173-180.

EPA. (2012). Guidelines for water reuse. Retrieved from Washington D.C:

Eriksson, E., Auffarth, K., Eilersen, A. M., Henze, M., \& Ledin, A. (2003). Household chemicals and personal care products as sources for xenobiotic organic compounds in grey wastewater. Water Sa, 29(2), 135-146.

Eriksson, E., Auffarth, K., Henze, M., \& Ledin, G. (2002). Characteristics of Grey wastewater Urban Water, 4(1), 85-104.

Eriksson, E., Srigirisetty, S., \& Eilersen, A. M. (2010). Organic matter and heavy metals in grey-water sludge. Water Sa, 36(1), 139-142.

Errais, E., Duplay, J., Darragi, F., M'Rabet, I., Aubert, A., Huber, F., \& Morvan, G. (2011). Efficient anionic dye adsorption on natural untreated clay: Kinetic study and thermodynamic parameters. Desalination, 275(1-3), 74-81. doi:10.1016/j.desal.2011.02.031

Escher, B. I., \& Fenner, K. (2011). Recent advances in environmental risk assessment of transformation products. Environ Sci Technol, 45(9), 3835-3847. doi:10.1021/es1030799

Faraqui, N., \& Al-Jayyousi, O. (2002). Greywater reuse in urban agriculture for poverty alleviation. A case study in Jordan. Water International, 27(3), 387-394.

Fatta-Kassinos, D., Kalavrouziotis, I. K., Koukoulakis, P. H., \& Vasquez, M. I. (2011). The risks associated with wastewater reuse and xenobiotics in the agroecological environment. Sci Total Environ, 409(19), 3555-3563. doi:10.1016/j.scitotenv.2010.03.036

Field, A. (2014). Discovering statistics using IBM SPSS Statistics. London: Sage.

Fielding, K. S., McDonald, R., \& Louis, W. R. (2008). Theory of planned behaviour, identity and intentions to engage in environmental activism. Journal of Environmental Psychology, 28(4), 318-326. doi:10.1016/j.jenvp.2008.03.003

Finley, S., Barrington, S., \& Lyew, D. (2009). Reuse of Domestic Greywater for the Irrigation of Food Crops. Water Air and Soil Pollution, 199(1-4), 235-245. doi:10.1007/s11270-008-9874-x

Fishebein, M., \& Ajzen, I. (2015). Predicting and changing behaviour: The Reasoned Action approach. New York: Routledge. 
Ford, R. M., Williams, K. J. H., Bishop, I. D., \& Webb, T. (2009). A value basis for the social acceptability of clearfelling in Tasmania, Australia. Landscape and Urban Planning, 90(3-4), 196-206. doi:10.1016/j.landurbplan.2008.11.006

Friedler, E. (2004). Quality of individual domestic greywater streams and its implication for on-site treatment and reuse possibilityes. Environmental Technology, 25, 997-1008.

Friedler, E., Kovalio, R., \& Ben-Zvi, A. (2006). Comparative study of the microbial quality of greywater treated by three on-site treatment systems. Environ Technol, 27(6), 653-663. doi:10.1080/09593332708618674

Friedler, E., Lahav, E., Jizhaki, H., \& Lahav, T. (2006). Study of urban population attitudes towards various wastewater reuse options: Isreal as a case study. Journal of Environmental Management, 81, 360-370.

Friedler, E., Yardeni, A., Gilboa, Y., \& Alfiya, Y. (2011). Disinfection of greywater effluent and regrowth potential of selected bacteria. Water Sci Technol, 63(5), 931-940. doi:10.2166/wst.2011.272

Futalan, C. M., Kan, C. C., Dalida, M. L., Pascua, C., \& Wan, M. W. (2011). Fixed-bed column studies on the removal of copper using chitosan immobilized on bentonite. Carbohydrate Polymers, 83(2), 697-704. doi:10.1016/j.carbpol.2010.08.043

Gale, F. S. (2017). Battling water scarcity: direct potable reuse poised as future of water recycling. Retrieved from http://www.waterworld.com/articles/print/volume-29/issue-9/editorialfeatures/battling-water-scarcity.html

Ghaed, S., Marandi, R., \& Mazhar, F. (2015). Removal of BOD5 and COD from saline wastewater using fixed bed colum of Aspergillun oryzea and Halobacillus dabanensis. Current world environment, 10(3), 830-838.

Ghana., E. (2000). General Environmental Quality standards. Ghana: EPA.

Gifford, R., \& Nilsson, A. (2014). Personal and social factors that influence pro-environmental concern and behaviour: A review. International Journal of Psychology, 49(3), 141-157. doi:10.1002/ijop.12034

Gilboa, Y., \& Friedler, E. (2008). UV disinfection of RBC-treated light greywater effluent: kinetics, survival and regrowth of selected microorganisms. Water Research, 42(4-5), 1043-1050. doi:10.1016/j.watres.2007.09.027

Gleick, P. (1993). Water in Crisis. A guide to the world's fresh water resources. Oxford: Oxford University Press.

Gross, A. (2008). Reliability of small scale greywater treatment systems and the impact of its effluent on soil properties. Int J Environ Stud, 65(1), 41-50.

Gross, A., Azulai, N., Oron, G., Ronen, Z., Arnold, M., \& Nejidat, A. (2005). Environmental impact and health risks associated with greywater irrigation: a case study. Water Sci Technol, 52(8), 161169.

Gross, A., Shmueli, O., Ronen, Z., \& Raveh, E. (2007). Recycled vertical flow constructed wetland (RVFCW)--a novel method of recycling greywater for irrigation in small communities and households. Chemosphere, 66(5), 916-923. doi:10.1016/j.chemosphere.2006.06.006

GSS. (2014). 2010 Population and housing census: District analytical report. Komenda-Edina-EguafoAbirim Municipal. Retrieved from Accra:

GTZ. (2005). Ecosan project. Urban upgrading project. Retrieved from http://www.indiawaterportal.org/sites/indiawaterportal.org/files/ecosan cd/material/D recom mended-reading/07 project-data-sheets/en-ecosan-pds-010-mali-koulikoro-2005.pdf

Haarhoff, J., \& VanderMerwe, B. (1996). Twenty-five years of wastewater reclamation in Windhoek, Namibia. Water Science and Technology, 33(10-11), 25-35. doi:Doi 10.1016/02731223(96)00403-9 
Hair, J. F., Anderson, R. E., Tatham, R. L., \& Black, W. C. (2014). Multivariate Data Analysis, Eight Edition. New Yersey: Prentice-Hall.

Halalsheh, M., Dalahmeh, S., Sayed, M., Suleiman, W., Shareef, M., Mansour, M., \& Safi, M. (2008). Grey water characteristics and treatment options for rural areas in Jordan. Bioresour Technol, 99(14), 6635-6641. doi:10.1016/j.biortech.2007.12.029

Hamdaoui, O., \& Naffrechoux, E. (2007). Modeling of adsorption isotherms of phenol and chlorophenols onto granular activated carbon - Part I. Two-parameter models and equations allowing determination of thermodynamic parameters. Journal of Hazardous Materials, 147(1-2), 381394. doi:10.1016/j.jhazmat.2007.01.021

Han, R. P., Ding, D. D., Xu, Y. F., Zou, W. H., Wang, Y. F., Li, Y. F., \& Zou, L. (2008). Use of rice husk for the adsorption of congo red from aqueous solution in column mode. Bioresource Technology, 99(8), 2938-2946. doi:10.1016/j.biortech.2007.06.027

Hararah, M. A., Ibrahim, K. A., Al-Muhtaseb, A. H., Yousef, R. I., Abu-Surrah, A., \& Qatatsheh, A. (2010). Removal of Phenol from Aqueous Solutions by Adsorption onto Polymeric Adsorbents. Journal of Applied Polymer Science, 117(4), 1908-1913. doi:10.1002/app.32107

Harindra, C. (2001). Appropriate disposal of sewage in urban and suburban Sri Lanka. (PhD), University of Leeds UK.

Harland, P., Staats, H., \& Wilke, H. A. M. (1999). Explaining proenvironmental intention and behavior by personal norms and the theory of planned behavior. Journal of Applied Social Psychology, 29(12), 2505-2528. doi:DOI 10.1111/j.1559-1816.1999.tb00123.x

Hendrawati, Yuliastri, R. I., Nurhasni, Rohaeti, E., Effendi, H., \& Darusman, K. L. (2016). The use of Moringa Oleifera Seed Powder as Coagulant to Improve the Quality of Wastewater and Ground Water. Earth and Environmental Science, 31.

Hernandez Leal, L., Temmink, H., Zeeman, G., \& Buisman, C. (2010). Comparison of three systems for biological greywater treatment. Water, 2, 155-169.

Hernandez Leal, L., Zeeman, G., Temmink, H., \& Buisman, C. (2007). Characterisation and biological treatment of greywater. Water Sci Technol, 56(5), 193-200. doi:10.2166/wst.2007.572

Hidayu, A. R., \& Muda, N. (2016). Preparation and characterization of impregnated activated carbon from palm kernel shell and coconut shell for CO2 capture. Procedia Engineering, 148, 106-113. doi:10.1016/j.proeng.2016.06.463

Higgins, J., Warnken , J., Sherman, P. P., \& Teasdale, P. R. (2002). Surveys of users and providers of recycled water: quality concerns and directions of applied research. Water Research vol 36, 5045-5056.

Hophmayer-Tokich, S. (2010). Wastewater management strategy: centralized v. decentralized technologies for small communities. Retrieved from

Hu, M., Zhang, T., Stansbury, J., Dahab, M., Shi, J., Neal, J., .. . Shen, Z. (2011). Treatment of greywater with shredded-tire biofilters and membrane bioreactors. Paper presented at the World Environmental and Water Resources Congress: Bearing knowledge for sustainability.

Huelgas, A., \& Funamizu, N. (2010). Flat-plate submerged membrane bioreactor for the treatment of higher-load graywater. Desalination, 250(1), 162-166. doi:10.1016/j.desal.2009.05.007

Hurliman, A., \& Dolnicar, S. (2013). When public opposition defeats alternative water projects -the case of Toowoomba Australia. Water Resources, 44, 287-297.

Hurliman, A., \& McKay, J. (2007). Urban Australia using recycled water for domestic non-potable use An evaluation of the attributes price, saltiness, colour and odour using cojoint analysis. Journal of Environmental Management, 83, 93-104.

Hurlimann, A., Hemphill, E., McKay, J., \& Geursen, G. (2008). Establishing components of community satisfaction with recycled water use through a structural equation model. J Environ Manage, 88(4), 1221-1232. doi:10.1016/j.jenvman.2007.06.002 
Hutcheson, G., \& Sofroniou, N. (1999). The multivariate social scientist London: Sage.

ICDD. (2018). Powder diffraction file.

Jakobi, G., \& Lohr, A. (1987). Detergents and Textile washing. Weinheim: VCH.

Jamrah, A., Al-Futaisi, A., Prathapar, S., Ahmed, M., \& Al-Harrasi, A. (2008). Evaluating greywater reuse potential for sustainable water resources management in Oman. Environmental monitoring and Assessment.

Jamrah, A., Al-Futaisi, A., Prathapar, S., \& Harrasi, A. A. (2008). Evaluating greywater reuse potential for sustainable water resources management in Oman. Environ Monit Assess, 137(1-3), 315-327. doi:10.1007/s10661-007-9767-2

Jamrah, A., Al Omari, A., Al Qasem, L., \& Abdel Ghani, N. (2011). Assessment of availability and characteristics of freywater in Amman. Water Sci Technol, 50(2), 157-164.

Jeffery, P. (2001). Understanding public receptivity issues regarding 'in-house' water recycling. Results from a UK survey. Retrieved from Cranfield UK:

Jokerst, A., Sharvelle, S. E., Hollowed, M. E., \& Roesner, L. A. (2011). Seasonal performance of an outdoor constructed wetland for graywater treatment in a temperate climate. Water Environ Res, 83(12), 2187-2198.

Jong, J., Lee, J., Kim, J., Hyun, K., Hwang, T., Park, J., \& Choung, Y. (2010). The study of pathogenic microbial communities in graywater using membrane bioreactor. Desalination, 250(2), 568-572. doi:10.1016/j.desal.2009.09.025

Kaiser, F. G. (2006). A moral extension of the theory of planned behavior: Norms and anticipated feelings of regret in conservationism. Personality and Individual Differences, 41(1), 71-81. doi:10.1016/j.paid.2005.11.028

Kantanonleon, N., Zampetakis, L., \& Manios, T. (2007). Public perception towards wastewater reuse in a medium size, seaside mediterranean city: A pilot survey. Resources conservation and recycling, 50, 282-292.

Karimi, M., Shojaei, A., Nematollahzadeh, A., \& Abdekhodaie, M. J. (2012). Column study of Cr (VI) adsorption onto modified silica-polyacrylamide microspheres composite. Chemical Engineering Journal, 210, 280-288. doi:10.1016/j.cej.2012.08.046

Katukiza, A. Y., Ronteltap, M., Niwagaba, C. B., Kansiime, F., \& Lens, P. N. L. (2014). Grey water characterisation and pollutant loads in an urban slum. International Journal of Environmental Science and Technology, 12(2), 423-436. doi:10.1007/s13762-013-0451-5

Khalaphallah, R., \& Andres, Y. (2012). The effect of various abiotic factors on the survival growth of Escherichia coli and Pseudomonas aeruginosa in bathroom greywater. Journal of Water Reuse and Desalination, 2(2), 92-101. doi:10.2166/wrd.2012.076

Kim, J., Song, I., Oh, H., Jong, J., Park, J., \& Choung, Y. (2009). A laboratory-scale graywater treatment system based on a membrane filtration and oxidation process - characteristics of graywater from a residential complex. Desalination, 238(1-3), 347-357. doi:10.1016/j.desal.2008.08.001

Klockner, C. A. (2013). A comprehensive model of the psychology of environmental behaviour-A metaanalysis. Global Environmental Change-Human and Policy Dimensions, 23(5), 1028-1038. doi:10.1016/j.gloenvcha.2013.05.014

Kohler, J. (2006). Detergent phosphates: an EU policy assessment. Journal of Business Chemistry, 3(2), 15-30.

Krishnan, V., Ahmad, D., \& Jeru, J. B. (2008). Influence of COD :;N : P ratio on dark greywater treatment using a sequencing batch reactor. Journal of Chemical Technology and Biotechnology, 83(5), 756-762. doi:10.1002/jctb.1842

Lamine, M., Bousselmi, L., \& Ghrabi, A. (2007). Biological treatment of grey water using sequencing batch reactor. Desalination, 215(1-3), 127-132. doi:10.1016/j.desal.2006.11.017 
Lange, K. R. (1994). Detergents and cleaners, A Handbook for formulators. New York: Schoder Druck $\mathrm{GmbH}$ and Co. KG.

Le-Minh, N., Khan, S. J., Drewes, J. E., \& Stuetz, R. M. (2010). Fate of antibiotics during municipal water recycling treatment processes. Water Research, 44(15), 4295-4323. doi:10.1016/j.watres.2010.06.020

Leal, H. L., Zeeman, H., \& Buisman, C. (2011). Characterization and anaerobic biodegradability of greywater. Desalination, 270, 111-115.

Ledin, A., Eriksson, E., \& Henze, M. (2001). Aspects of groundwater recharge using grey wastewater. In P. Lens, G. Zeeman, \& G. Lettinga (Eds.), Decentralised sanitation and reuse: Concepts, systems and implementation (pp. 354-370). London: IWA Publishing.

Li, F., Wichmann, K., \& Otterpohl, R. (2009). Review of the technological approaches for grey water treatment and reuses. Sci Total Environ, 407(11), 3439-3449. doi:10.1016/j.scitotenv.2009.02.004

Lin, X. Q., Li, R. J., Wen, Q. S., Wu, J. L., Fan, J. S., Jin, X. H., . . Ying, H. J. (2013). Experimental and modeling studies on the sorption breakthrough behaviors of butanol from aqueous solution in a fixed-bed of KA-I resin. Biotechnology and Bioprocess Engineering, 18(2), 223-233. doi:10.1007/s12257-012-0549-5

Lopez-Cervantes, J., Sanchez-Machado, D. I., Sanchez-Duarte, R. G., \& Correa-Murrieta, M. A. (2018). Study of a fixed-bed column in the adsorption of an azo dye from an aqueous medium using a chitosan-glutaraldehyde biosorbent. Adsorption Science \& Technology, 36(1-2), 215-232. doi:10.1177/0263617416688021

Mahmoud, N., Amarneh, M. N., Al-Sa'ed, R., Gijzen, H., \& Lettinga, G. (2003). Sewage characterization as a tool for the application of anaerobic treatment in Palestine. Environmental Pollution, 126, 115122.

Maimon, A., Friedler, E., \& Gross, A. (2014). Parameters affecting greywater quality and its safety for reuse. Sci Total Environ, 487, 20-25. doi:10.1016/j.scitotenv.2014.03.133

Mandal, D., Labhasetwar, P., Dhone, S., Dubey, A. S., Shinde, G., \& Wate, S. (2011). Water conservation due to greywater treatment and reuse in urban setting with specific context to developing countries. Resources conservation and recycling, 55(3), 356-361. doi:10.1016/j.resconrec.2010.11.001

Mangaleshwaran, L., Thirulogachandar, A., Rajasekar, V., Muthukumaran, C., \& Rasappan, K. (2015). Batch and fixed bed column studies on nickel (II) adsorption from aqueous solution by treated polyurethane foam. Journal of the Taiwan Institute of Chemical Engineers, 55, 112-118. doi:10.1016/j.jtice.2015.03.034

March, J. G., \& Gual, M. (2007). Breakpoint chlorination curves of greywater. Water Environ Res, 79(8), 828-832.

March, J. G., Gual, M., \& Simonet, B. M. (2004). A sensitive extracto-photometric method for determination of residual chlorine in greywater. J AOAC Int, 87(4), 852-855.

Marks, J. S. (2006). Taking the public seriously: the case of Potable and Non Potable Reuse. Desalination Vol 187, 137-147.

Marks, M. (2004). Advancing community acceptance of reclaimed water. Water journal of the Australian Water Association, 31(5), 46-51.

Masi, F., El Hamouri, B., Abdel Shafi, H., Baban, A., Ghrabi, A., \& Regelsberger, M. (2010). Treatment of segregated black/grey domestic wastewater using constructed wetlands in the Mediterranean basin: the zer0-m experience. Water Sci Technol, 61(1), 97-105. doi:10.2166/wst.2010.780

Meehan, K., Ormerod, K. J., \& Moore, S. (2013). Remaking waste as water: the governance of recycled effluent for potable water supply. Water Alternative(6), 67-85. 
Menge, J. (2010). Treatment of wastewater for re-use in the drinking water system of Windhoek. Retrieved from http://www.wastewater.co.za/images/files/Treatment of wastewater for Drinking Water in Windhoek J Menge.pdf

Merz, C., Scheumann, R., El Hamouri, B., \& Kraume, M. (2007). Membrane bioreactor technology for the treatment of greywater from a sports and leisure club. 215, 37-43.

Mohamed, R. M., Kassim, A. H., Anda, M., \& Dallas, S. (2013). A monitoring of environmental effects from household greywater reuse for garden irrigation. Environ Monit Assess, 185(10), 84738488. doi:10.1007/s10661-013-3189-0

Mohammad-Khah, A., \& Ansari, R. (2009). Activated charcoal: preparation, characterization and applications: a review article. . Int J Chem Tech, 1(4), 859-864.

Mondal, P., Mehta, D., Saharan, V. K., \& George, S. (2018). Continuous Column Studies for Water Defluoridation Using Synthesized Magnesium-incorporated Hydroxyapatite Pellets: Experimental and Modeling Studies. Environmental Processes-an International Journal, 5(2), 261-285. doi:10.1007/s40710-018-0287-6

Mook, W. T., Aroua, M. K., \& Szlachta, M. (2016). Palm Shell-based Activated Carbon for Removing Reactive Black 5 Dye: Equilibrium and Kinetics Studies. Bioresources, 11(1), 1432-1447.

Morel, A., \& Diener, S. (2006). Greywater Management in low and middle-income countries, review of different treatment systems for households or neighbourhoods. Retrieved from

Nancarrow, B. E., Leviston, Z., Po, M., Porter, N. B., \& Tucker, D. I. (2008). What drives communities' decisions and behaviours in the reuse of wastewater. Water Science and Technology, 57(4), 485491. doi:10.2166/wst.2008.160

NAS. (2012). Water reuse potential for expanding the Nations water supply through reuse of municipal wastewater. Retrieved from Washington DC:

Nayl, A. A., Elkhashab, R. A., El Malah, T., Yakout, S. M., El-Khateeb, M. A., Ali, M. M. S., \& Ali, H. M. (2017). Adsorption studies on the removal of COD and BOD from treated sewage using activated carbon prepared from date palm waste. Environmental Science and Pollution Research, 24(28), 22284-22293. doi:10.1007/s11356-017-9878-4

Nekoo, S. H., \& Shohreh, F. (2013). Experimental study and adsorption modelling of COD reduction in activated carbon from wastewater treatment of oil refinery. Iran Journal of Chemistry and Chemical Engineering, 32(3), 81-89.

Nguyen, A. H., Ngo, H. H., Guo, W. S., Pham, T. Q., Li, F. M., Nguyen, T. V., \& Bui, X. T. (2015). Adsorption of phosphate from aqueous solutions and sewage using zirconium loaded okara (ZLO): Fixed-bed column study. Science of the Total Environment, 523, 40-49. doi:10.1016/j.scitotenv.2015.03.126

O'Toole, J., Sinclair, M., Malawaraarachchi, M., Hamilton, A., Barker, S. F., \& Leder, K. (2012). Microbial quality assessment of household greywater. Water Research, 46(13), 4301-4313. doi:10.1016/j.watres.2012.05.001

Omerod, K. J., \& Scott, C. A. (2013). Drinking wastewater: Public trust in potable reuse. Science Technology and Human Values, 38, 351-373.

Onyango, L., Leslie, G., \& Wood, J. G. (2014). Global potable reuse case study 4: Windhoek, Namibia. Retrieved from Brisbane, Australia:

Oteng-Peprah, M., Acheampong, M. A., \& deVries, N. K. (2018). Greywater Characteristics, Treatment Systems, Reuse Strategies and User Perception-a Review. Water, Air, \& Soil Pollution, 229(8), 255. doi:10.1007/s11270-018-3909-8

Oteng-Peprah, M., De Vries, N., \& Acheampong, M. A. (2019). Exploring the potential of activated carbon prepared from palm kernel shell and tropical almond in BOD and COD removal from domestic greywater. 
Oteng-Peprah, M., de Vries, N. K., \& Acheampong, M. A. (2018). Greywater characterization and generation rates in a peri urban municipality of a developing country. J Environ Manage, 206, 498-506. doi:10.1016/j.jenvman.2017.10.068

Ottoson, J., \& Stenstrom, T. A. (2003). Faecal contamination of greywater and associated microbial risks. Water Research, 37, 645-655.

Palmquist, H., \& Hanaeus, J. (2005). Hazardous substances in separately collected grey- and blackwater from ordinary Swedish households. Sci Total Environ, 348(1-3), 151-163. doi:10.1016/j.scitotenv.2004.12.052

Pamidimukkala, P. S., \& Soni, H. (2018). Efficient removal of organic pollutants with activated carbon derived from palm shell: Spectroscopic characterisation and experimental optimisation. Journal of Environmental Chemical Engineering, 6(2), 3135-3149. doi:10.1016/j.jece.2018.04.013

Parjane, S. B., \& Sane, M. G. (2011). Performance of greywater treatment plant by economical way for Indian rural development. Int. J Chem Tech Res, 3(4), 1808-1815.

Parkinson, J. (2008). Waste not: the facts about indirect potable reuse. Humanist, 68, 4-6.

Patel, H., \& Vashi, R. T. (2012). Fixed bed column adsorption of ACID Yellow 17 dye onto Tamarind Seed Powder. Canadian Journal of Chemical Engineering, 90(1), 180-185. doi:10.1002/cjce.20518

Patel, H., \& Vashi, R. T. (2015). Characterization and column adsorptive treatment for COD and colour removal using activated neem leaf powder from textile wastewater. Journal of urban and environmental engineering, 9(1), 45-53.

Pathan, A. A., Mahar, R. B., \& Ansari, K. (2011). Preliminary study of greywater treatment through rotating biological contactor. Mehran Univ Res J Eng Technol, 30, 531-538.

Paulo, P. L., Begosso, L., Pansonato, N., Shrestha, R. R., \& Boncz, M. A. (2009). Design and configuration criteria for wetland systems treating greywater. Water Sci Technol, 60(8), 2001-2007. doi:10.2166/wst.2009.542

Peters, A., Gutscher, H., \& Scholz, R. W. (2011). Psychological determinants of fuel consumption of purchased new cars. Transportation Research Part F-Traffic Psychology and Behaviour, 14(3), 229-239. doi:10.1016/j.trf.2011.01.003

Pidou, M., Avery, L., Stephenson, T., Jeffrey, P., Parsons, S. A., Liu, S., ... Jefferson, B. (2008). Chemical solutions for greywater recycling. Chemosphere, 71(1), 147-155. doi:10.1016/j.chemosphere.2007.10.046

Prathapar, S. A., Jamrah, A., Ahmed, M., Al Adawi, S., Al Sidairi, S., \& Al Harassi, A. (2005). Overcoming constraints in treated greywater reuse in Oman. Desalination, 186(1-3), 177-186. doi:10.1016/j.desal.2005.01.018

Quintal, V. A., Lee, J. A., \& Soutar, G. N. (2010). Risk, uncertainty and the theory of planned behavior: A tourism example. Tourism Management, 31(6), 797-805. doi:10.1016/j.tourman.2009.08.006

Qureshi, M. E., \& Hanjra, M. A. (2010). Global water crisis and future security in an era of climate change. Food Policy, 35(5), 365-377. doi:10.1016/j.foodpol.2010.05.006

Ramona, G., Green, M., Semiat, R., \& Dosoretz, C. (2004). Low strength graywater characterization and treatmentby direct membrane filtration. Desalination, 170(3), 241-250. doi:10.1016/j.desal.2004.02.100

Revitt, D. M., Eriksson, E., \& Donner, E. (2011). The implications of household greywater treatment and reuse for municipal wastewater flows and micropollutant loads. Water Research, 45(4), 15491560. doi:10.1016/j.watres.2010.11.027

Roson, R., \& Damania, R. (2017). The macroeconomic impact of future water scarcity An assessment of alternative scenarios. Journal of Policy Modeling, 39(6), 1141-1162. doi:10.1016/j.jpolmod.2017.10.003

Russell, S., Lux, C., \& Hampton, G. (2009). Information: Integrating consultation and education for water recycling initiatives. Social and Natural Resrouces, 22, 46-65. 
Sahar, S. D., Mikael, P., Bjorn, V., Lars, D. H., Ingrid, O., \& Hakan, J. (2012). Efficiency of bark, activated charcoal, foam and sand filters in reducing pollutants from greywater. Water Air and Soil Pollution, 223, 3657-3671.

SANDEC. (2006). Greywater management in low and middle income countries (14/06). Retrieved from Switzerland:

Sartape, A. S., Mandhare, A. M., Salvi, P. P., Pawar, D. K., \& Kolekar, S. S. (2013). Kinetic and equilibrium studies of the adsorption of $\mathrm{Cd}(\mathrm{II})$ from aqueous solutions by wood apple shell activated carbon. Desalination and Water Treatment, 51(22-24), 4638-4650. doi:10.1080/19443994.2012.759158

Schalkwyk, V. A. (1996). Guidelines for the estimation of domestic water demand of developing countries in the Northern Trasnvaal. Retrieved from

Scheumann, R., \& Kraume, M. (2009). Influence of hydraulic retention time on the operation of a submerged membrane sequencing batch reactor (SM-SBR) for the treatment of greywater. Desalination, 246(1-3), 444-451. doi:10.1016/j.desal.2008.03.066

Schwartz, S. H., \& Tessler, R. C. (1972). A test of a model for reducing measured attitude-behaviour discrepancies. Journal of personality and social psychology, 24, 225-235.

Scott, M. J., \& Jones, M. N. (2000). The biodegradation of surfactants in the environment. Biochim Biophys Acta, 1508(1-2), 235-251.

Sheng, L. P., Zhang, Y., Tang, F. J., \& Liu, S. (2018). Mesoporous/microporous silica materials: Preparation from natural sands and highly efficient fixed-bed adsorption of methylene blue in wastewater. Microporous and Mesoporous Materials, 257, 9-18. doi:10.1016/j.micromeso.2017.08.023

Shoults, D. C., \& Ashbolt, N. J. (2017). UV Disinfection of Hand-Rinse Greywater and Performance Testing Using Indigenous Staphylococcus spp. Water, 9(12). doi:ARTN 963

10.3390/w9120963

Shresta, R. R. (1999). Application of constructed wetlands for wastewater treatment in Nepal. (PhD), University of Agricultural Sciences, Vienna, Vienna

Shrestha, R. R., Haberl, R., \& Laber, J. (2001). Application of constructed wetlands for wastewater treatment in Nepal. Water Science and Technology, 44, 381-386.

Sievers, J. C., Watzel, T., Londong, J., \& Kraft, E. (2016). Case study: characterization of source-separated blackwater and greywater in the ecological housing estate Lubeck "Flintenbreite" (Germany). Environmental Earth Sciences, 75(22). doi:ARTN 1428

10.1007/s12665-016-6232-y

Siggins, A., Burton, V., Ross, C., Lowe, H., \& Horswell, J. (2016). Effects of long-term greywater disposal on soil: A case study. Sci Total Environ, 557-558, 627-635. doi:10.1016/j.scitotenv.2016.03.084

Singha, S., \& Sarkar, U. (2015). Analysis of the dynamics of a packed column using semi-empirical models: Case studies with the removal of hexavalent chromium from effluent wastewater. Korean Journal of Chemical Engineering, 32(1), 20-29. doi:10.1007/s11814-014-0183-3

Taghipour, H., \& Mosaferi, M. (2013). Heavy metals in the vegetables collected from production sites. Health Promot Perspect, 3(2), 185-193. doi:10.5681/hpp.2013.022

Tan, I. A. W., Ahmad, A. L., \& Hameed, B. H. (2008). Adsorption of basic dye using activated carbon prepared from oil palm shell: batch and fixed bed studies. Desalination, 225(1-3), 13-28. doi:10.1016/j.desal.2007.07.005

Tavakkoli, E., Fatehi, F., Coventry, S., Rengasamy, P., \& McDonald, G. K. (2011). Additive effects of Na+ and $\mathrm{Cl}$ - ions on barley growth under salinity stress. J Exp Bot, 62(6), 2189-2203. doi:10.1093/jxb/erq422

Tchobanoglous, G., Burton, F., \& Stensel, D. (2002). Wastewater Engineering Treatment and Reuse. New York: McGraw-Hill Higher Education. 
Tchobanoglous, G., Burton, F., \& Stensel, D. (2003). Wastewater engineering treament and reuse 4th edition. New York: McGraw Hill Education.

Teutscherova, N., Houska, J., Navas, M., Masaguer, A., Benito, M., \& Vazquez, E. (2018). Leaching of ammonium and nitrate from Acrisol and Calcisol amended with holm oak biochar: A column study. Geoderma, 323, 136-145. doi:10.1016/j.geoderma.2018.03.004

Thogersen, J., \& Olander, F. (2006). The dynamic interaction of personal norms and environmentfriendly buying behavior: A panel study. Journal of Applied Social Psychology, 36(7), 1758-1780. doi:DOI 10.1111/j.0021-9029.2006.00080.x

Thomas, H. C. (1944). Heterogeneous ion exchange in the flowing system. Jounal of the American Chemical Soceity, 66(10), 1664-1666.

TIGG, L. (2019). Granular activated carbon (GAC) media selection Retrieved from https://tigg.com/resources/activated-carbon-knowledge-base/granular-activated-carbon-gacmedia-selection/

Tonglet, M., Phillips, P. S., \& Bates, M. P. (2004). Determining the drivers for householder proenvironmental behaviour: waste minimisation compared to recycling. Resources conservation and recycling, 42(1), 27-48. doi:10.1016/j.resconrec.2004.02.001

Travis, M. J., Wiel-Shafran, A., Weisbrod, N., Adar, E., \& Gross, A. (2010). Greywater reuse for irrigation: effect on soil properties. Sci Total Environ, 408(12), 2501-2508. doi:10.1016/j.scitotenv.2010.03.005

UN. (1992). The Earth Summit. Paper presented at the Environment and development Summit, Rio de Janeiro, Brazil.

UNDP. (2015). Widening inequality; a universal issue. The sustainable development goals. Retrieved from https://www.undp.org/content/undp/en/home/sustainable-development-goals.html

UNDP. (2017). Sustainable Development Goals. Goal 6 Targets Facts and Figures. Retrieved from http://www.undp.org/content/undp/en/home/sustainable-development-goals/goal-6-cleanwater-and-sanitation/targets/

UNESCO. (2009). World water assessment program - Water in a changing world. Retrieved from Paris:

UNICEF. (2012). Definitions. Retrieved from https://www.unicef.org/sowc2012/pdfs/SOWC-2012DEFINITIONS.pdf

UNICEF. (2016). Progress on sanitation and drinking water-2015 update and MDG assessment Retrieved from USA:

USEPA. (2012). Guidelines for Water Reuse. Washington DC.

USSL. (1954). Diagnosis and improvement of saline and alkali soils: US department of Agriculture Handbook: US Salinity Laboratory Staff.

Vigneswaran, S., \& Sundaravadivel, M. (2004). Recycle and reuse of domestic wastewater in Wastewater recycle, reuse and reclamation. Oxford: EOLSS.

Vorosmarty, C. J., Douglas, E. M., Green, P. A., \& Revenga, C. (2005). Geospatial indicators of emerging water stress: An application to Africa. Ambio, 34(3), 230-236. doi:Doi 10.1639/00447447(2005)034[0230:Gioews]2.0.Co;2

Vorosmarty, C. J., McIntyre, P. B., Gessner, M. O., Dudgeon, D., Prusevich, A., Green, P., . . Davies, P. M. (2010). Global threats to human water security and river biodiversity. Nature, 467(7315), 555561. doi:10.1038/nature09440

Wauters, E., Bielders, C., Poesen, J., Govers, G., \& Mathijs, E. (2010). Adoption of soil conservation practices in Belgium: An examination of the theory of planned behaviour in the agrienvironmental domain. Land Use Policy, 27(1), 86-94. doi:10.1016/j.landusepol.2009.02.009

Westrell, T., Schonning, C., Stenstrom, T. A., \& J., A. N. (2004). Quantitative microbial risk assessment (QMRA) and Hazard analysis and critical control points (HACCP) for management of pathogens in wastewater and sewage sludge treatment and reuse. Water sci Technology, 50(2), 23-30. 
WHO. (1996). Guidelines for drinking-water quality, 2nd Edition Vol 2. Genever: World Health Oganization.

WHO. (2006a). Guidelines for the safe use of wastewater, excreta and greywater Volume 2. France: WHO.

WHO. (2006b). Meeting the MDG drinking water and sanitation target : the urban and rural challenge of the decade. Retrieved from Switzerland:

WHO. (2019). World water day 2017: Why waste water. Retrieved from https://www.who.int/water_sanitation_health/news-events/world-water-day-2017/en/

WRF. (2015). Framework for direct potable reuse (J. J. Mosher \& G. M. Vartaniam Eds. Vol. 14-20). Alexandria: WaterReuse Research Foundation.

Xavier, A. L. P., Adarme, O. F. H., Furtado, L. M., Ferreira, G. M. D., da Silva, L. H. M., Gil, L. F., \& Gurgel, L. V. A. (2018). Modeling adsorption of copper(II), cobalt(II) and nickel(II) metal ions from aqueous solution onto a new carboxylated sugarcane bagasse. Part II: Optimization of monocomponent fixed-bed column adsorption. Journal of Colloid and Interface Science, 516, 431-445. doi:10.1016/j.jcis.2018.01.068

Yan, H. M., Du, X. J., Li, P., Yu, S. L., \& Tang, Y. L. (2015). Adsorption of Bromate From Aqueous Solutions by Modified Granular Activated Carbon: Batch and Column Tests. Ozone-Science \& Engineering, 37(4), 357-370. doi:10.1080/01919512.2014.1001020

Yoon, Y. H., \& Nelson, J. H. (1984). Application of gas adsorption kinetics; A theoretical model for respirator cartridge service time. Am. Ind. Hyg. Assoc. J, 45, 509-516.

Zhang, Z., Luo, X., Liu, Y., Zhou, P., Ma, G., Lei, Z., \& Lei, L. (2014). A low cost and highly efficient adsorbent (activated carbon) prepared from waste potato residue. Journal of Taiwan Institute of Chemical Engineers, 49, 206-211.

Zuma, B. M., R, T., Whittington-Jones, K. J., \& Burgess, J. E. (2009). Mulch tower treatment system. Part 1: overall performance in greywater treatment. Desalination, 242, 38-56. 


\section{Summary}

The findings in this study examine sustainable wastewater management in Ghana by exploring the option of greywater reuse at the household level. Urbanization in developing countries has brought about an increase in demand for potable water. Associated with this increase in demand is the generation of greywater resulting from the myriad of water use activities. The greywater discharged are mostly left untreated and mostly end up in rivers and other aquatic ecosystems that are sources of livelihood for humans and livestock which can lead to health risks. the main aim of this study is to explore the possibilities of reusing greywater to achieve sustainability as stated in the sustainable development goal 6 which is to ensure sustainable management of water and sanitation for all.

\section{Chapter 2}

Chapter two reviews relevant literature on greywater characteristics, treatment systems, reuse strategies and user perception. The chapter places special emphasis on greywater systems in developing countries. It emerged from this review that there is a wide variation in greywater characteristics and generation rates and this is influenced by lifestyle, fixtures used and climatic conditions. There are many technologies for treating greywater, however, available technologies have mostly been designed for a targeted pollutant. The study further established that most of the treatment systems were applicable on a large scale and this discourages household greywater treatment and reuse intentions. Considering the variations in characteristics and quality, it is, therefore, necessary to establish the quality of greywater before implementing any treatment or possible reuse scheme. The study further identified the impact of public perception as a key element in implementing greywater reuse. The study concludes that greywater treatment and reuse if embraced can lead to substantial decline in over-reliance on freshwater resources for potable and non-potable purposes.

\section{Chapter 3}

An assessment of greywater quality is necessary to decide on which contaminant to remove. This chapter presents the quality assessment and generation rates of greywater within the study area. This assessment involved grouping of households into households that had water on their premises and households that had to move out of their premises to access water. There were significant differences between the two groups of households with water consumption of houses with access at home being $82.51 \mathrm{l} / \mathrm{c} / \mathrm{d}$ and $36.65 \mathrm{I} / \mathrm{c} / \mathrm{d}$ for those who relied on external sources and return factors of $74.16 \%$ and $88.75 \%$ respectively. The study showed the majority of the pollutants in the greywater within the study area exceeded the Ghana EPA discharge guidelines and therefore not suitable for discharge without prior treatment. The discharged greywater was also identified not to be suitable for direct irrigation based on the salinity and sodium hazard analysis. Principal component analysis conducted on the data indicated that the characteristics of the greywater were influenced by cooking and cleaning practices, personal hygiene, biodegradability, frequency of water use before disposal and sanitary practices in the bathroom. The study concluded that the practice of discharging greywater into the environment is detrimental to the environment and a health risk to both humans and livestock. It is, therefore, necessary to start exploring household greywater treatment in such areas before final disposal or possible reuse.

\section{Chapter 4}

This chapter explores the application of two different locally available agricultural waste materials as sorbent material in reducing the $\mathrm{BOD}_{5}$ and $\mathrm{COD}$ of the greywater. These two parameters were chosen 
because they have been the parameters that are used to assess the level of pollution of wastewater before it is finally discharged. The two agricultural waste materials (tropical almond shell and palm kernel shells) which are common in the study area were used for the preparation of activated carbon. A batch adsorption study was conducted on greywater sample from the study area and reduction of as high as $76 \% \mathrm{BOD}_{5}$ and $65 \% \mathrm{COD}$ were obtained. From the study, it emerged that the palm kernel shell had larger internal surface and was able to perform better as compared to tropical almond shells. The equilibrium concentration for $\mathrm{BOD}_{5}\left(\mathrm{q}_{\mathrm{e}}=22.88 \mathrm{mg} / \mathrm{g}\right)$ and $\mathrm{COD}\left(\mathrm{q}_{\mathrm{e}}=34.00 \mathrm{mg} / \mathrm{g}\right)$ was achieved by palm shell activated carbon. The adsorption data were fitted to the adsorption isotherms and the best model that fitted this process was the Freundlich isotherm. The Freundlich isotherm model described $\mathrm{BOD}_{5}\left(R^{2}=0.98\right)$ removal and $\operatorname{COD}\left(R^{2}=0.65\right)$ removal with palm kernel shell as the adsorbent. The reduction of $B O D\left(R^{2}=0.99\right)$ and $\operatorname{COD}\left(R^{2}=0.97\right)$ followed pseudo-second order kinetics. The study identified palm kernel activated carbon to be a better material for removal of $\mathrm{BOD}_{5}$ and COD.

\section{Chapter 5}

The performance of a fixed-bed column packed with palm kernel activated carbon for the reduction of $\mathrm{BOD}_{5}$ and $\mathrm{COD}$ in greywater was evaluated using column breakthrough data at different flow rates and bed depths. The Yoon-Nelson, Thomas, Adams Bohart and Bed Depth Service Time (BDST) models were used to evaluate the design parameters of the column. A maximum uptake capacity of $35 \mathrm{mg} / \mathrm{g}$ and $54 \mathrm{mg} / \mathrm{g}$ was achieved for $\mathrm{BOD}_{5}$ and $\mathrm{COD}$ respectively. The Yoon-Nelson model provided a superior description of the kinetic data as compared to the Thomas model. The study concluded that the activated carbon prepared from palm kernel shell which is an agricultural waste material can be used to reduce the $\mathrm{BOD}_{5}$ and $\mathrm{COD}$ concentrations in greywater. the design of a fixed-bed column for $\mathrm{BOD}_{5}$ and $\mathrm{COD}$ removal from greywater can be based on these models.

\section{Chapter 6}

This chapter explored the determinants that influenced people's intentions to reuse greywater for either potable or non-potable purposes. This study adopted a socio-cognitive model known as the theory of planned behaviour (TPB) in identifying the construct that influences one's choice of reuse application thus potable or non-potable applications. The study was conducted taking into consideration the role of cultural practices, educational background, source of water and religious beliefs. It emerged that participants generally had a positive intention towards greywater reuse; however, potable reuse had a very strong negative intention indicating the unwillingness to reuse greywater for potable purposes. The study identified attitude and behavioural control as the two main constructs that affect intentions to reuse greywater for both reuse applications. It further emerged from the study that to promote greywater reuse, one intervention method that targets the two reuse applications is not likely to lead to effective outcomes. Interventions are to be targeted at the specific reuse application with its associated factors. From the study, it emerged that non-potable reuse approaches might be easier to implement as compared to potable reuses largely due to the perceived health risk associated with potable reuses. To promote potable reuses, the best mode of approach will be to address it from the perceived health risk and further enhance trust in the ability of the individual. The study concludes with a recommendation for assessing the willingness of households to adopt greywater treatment and reuse systems to promote household treatment. 


\section{Chapter 7}

This chapter explored the willingness of households to adopt a greywater and reuse system. The study adopted the theory of planned behaviour (TPB) in its original form and an extended model including personal norms. The personal norm was selected because it has been argued to improve the predictive ability in determining willingness for pro-environmental behaviours. Data was collected from 478 household heads within the study area. The results from analyzing the data using structural equation modelling indicated that the extended model with personal norms gave an improved fit and explained a higher percentage of the variance in the data as compared with the original TPB model. Although, all the four factors thus attitude, personal norms, subjective norms and perceived behavioural control seemed to all contribute to the intentions, however, attitudes and personal norms seem to be the dominant determinants. This indicates that to promote household participation in greywater treatment and reuse, it is imperative to tailor intervention methods around personal norms and attitudes. The results of this study can be applied by stakeholders who intend to promote greywater reuse in developing countries.

\section{Chapter 8}

This chapter summarizes the main findings from the different studies, the different methodologies adopted in data collection and analysis and the recommendations. From the main findings of this study, it can be concluded that greywater is discharged into the environment without treatment. Some of the pollutants analyzed in the greywater were above the regulatory limit of discharge without treatment and this is detrimental to both human and livestock. It also identified a locally available waste material which has a high potential of being used to reduce the $\mathrm{BOD}_{5}$ and $\mathrm{COD}$ levels in greywater. It further emerged from the study that, attitude and perceived behavioural control were the two main factors that influenced one's choice of either reusing greywater for potable or non-potable purposes. The willingness of households to adopt a treatment system at home was assessed. It emerged that attitude and personal norms were the two main factors that could be used in promoting household participation of greywater and reuse schemes. The study recommends the design a fully functional domestic greywater treatment and reuse system using the media studied in this research as the adsorptive media on a pilot scale. It further recommends a study that will explore the regenerative method of the media once it loses its treatment capacity and the proper disposal methods. It further recommends an institutional approach to greywater treatment and reuse which will address issues such as policy, economics, treatment quality guidelines and installation and design codes for buildings that will be interested in adopting this concept. 


\section{Valorization}

Access to adequate potable water has remained a problem in many developing countries. While this situation has received significant attention in some countries, many other countries continue to experience limited access to this resource. Lack of access can be associated with many conditions such as limited resource, polluted resource, limited technology among others. However, greywater which is less polluted is mostly discharged untreated into the environment in areas which do not have proper sewer networks. These unregulated discharges can then lead to environmental pollution of both soil and freshwater resources leading to environmental hazards. The high volumes of greywater discharged and the low level of contamination makes greywater a good resource that can be harnessed to augment water supplies in areas of limited access. The limited supply of water has a huge effect on sanitation practices and this can lead to bad sanitation practices which in the long run affect the environment and the individual. The research presented in this thesis provides an overview of greywater reuse in Ghana and forms the foundation for future studies in the area of greywater treatment and reuse in sub-Saharan Africa. This study, therefore, provides a stronger theoretical basis for future studies into greywater treatment and reuse schemes within the sub-region from both the socio-cognitive and technical points of view. It may also serve as an introduction to students, scholars, institutions and interested parties into greywater treatment and reuse.

It further underscores the importance of reusing greywater to supplement water use activities at the household level. Greywater treatment and reuse is a strategy that can reduce the pollution loads to the environment and further augment water supplies for other non-consumptive purposes. Adopting this greywater and treatment system can also lead to reduced water demand from freshwater resources and improved sanitation practices in water-stressed areas.

The economic consequence of lack of water or environmental pollution can translate into many deleterious effects such as the reduction in labour and productivity. The environmental challenges also caused by agricultural waste remain a concern to many in developing countries. The results reported in the thesis emphasize the increasing environmental pollution resulting from the discharge of untreated greywater into the environment. This study identified an agricultural waste that can be converted into suitable material for treating greywater. The application of this local material can promote local acceptability of the concept of greywater treatment and reuse and further create business opportunities for individuals and groups to exploit this material for economic benefits.

The study identified non-potable reuses as the preferred method of reuse application. Concerning beliefs, attitudes and behavioural control that influence the choice of reuse application, the study identified perceived behavioural control and attitude as the dominant significant antecedent of behavioural intentions toward reusing greywater for non-potable purposes. The inclusion of background factors also identified educational level as a distal factor that contributed to the behavioural intentions to reuse water for non-potable purposes. The study further established the willingness of households to begin implementing greywater treatment and reuse practices by adopting treatment systems. The outcome of this study led to the conclusion that personal norms played a major role in the willingness of household heads to begin greywater reuse. Therefore, interventions aimed at promoting greywater reuse should target personal norms rather than other factors. Such campaigns should use messages that appeal to the personal norms of the individual. 
This study contains valuable information surrounding the approach, strategy, potential pitfalls, appropriate treatment media and media performance in greywater treatment and reuse in developing countries. It is the first of its kind in Ghana documented in peer-reviewed publications and addresses the lack of data in the area of greywater reuse as a method of wastewater management practice in Ghana and the sub-region. Additional studies further investigating the real implementation of this concept and the environmental auditing of the impact of unregulated greywater discharge are needed to inform stakeholders on the way forward. Such a study should involve policymakers, environmental experts, development agencies and water quality experts.

Previous studies in some developed countries have used a singular approach in exploring greywater reuse and little has been known about how individuals make their decision to use or not to use greywater. Little has also been known about what informs the choice of the reuse application for greywater in these developed countries. To the best of our knowledge, no previous study has directly assessed these factors using socio-cognitive models in developing countries. In sum, a lot of the innovation lies in the statistical techniques used in this study which was a two-prong approach of socio-cognitive models and laboratory analysis. The lessons learned in this study such as the role of personal norms, level of education and gender has reinforced our understanding of the approach to adopt in implementing greywater and reuse strategies. 


\section{Acknowledgement}

Firstly, I will like to express my profound gratitude to my supervisor at the department of health promotion and Vice Dean of Faculty of Health, Medicine and Life Sciences (FHML) Prof Nanne de Vries. Your guidance, inputs, encouragement and great sense of humor I received throughout this work has strengthened my research skills and broadened my research perspective. You always had time for me to clarify my uncertainties despite your very busy schedule. You had your own way of making difficult tasks look so easy to accomplish. I consider myself very lucky to be supervised by you and I will forever treasure the knowledge you imparted to me.

To my co-supervisor, Prof Mike Agbesi Acheampong pro vice chancellor of the Kumasi Technical University, I say thank you for your inputs, constructive criticisms and direction. To the evaluation committee, I say thank you for the very insightful inputs you made into the thesis. Your contributions to the work are very much appreciated.

I am grateful to the Netherlands Organization for International Cooperation in Higher Education (NUFFIC) for the financial support that made this work a success. I thank my Institution (University of Cape Coast) for the support they offered throughout my study in the Netherlands.

To my loving wife, Doris Oteng-Peprah and my beloved children, Dufie, Nhyira and Michael who give so much happiness and a reason to aspire to greater heights; I thank God for bringing you into my life. To my wife, thank you for all your understanding and encouragement especially for those times when I had to leave you and the children for a long time to be in Maastricht for my studies. Though I was not around, you always made sure I was okay wherever I went by continually keeping in touch. I appreciate all the efforts and support you made to make sure I had peace of mind to study. We have come this far together and I say thank you so much. I also thank my parents Mr. and Mrs. Oteng for always being there for me, encouraging and supporting me in your own way.

To Heinz Greijn, you are such an amazing person. You made my stay in the Netherlands so enjoyable and hassle-free. You were always there to support, assist and encourage. Despite your very busy schedules, you still managed to have some time to be with me and my colleagues. I also thank Pastor Benjamin Odetola and his family for making me feel at home anytime I am in Maastricht. Your encouragement, prayers, advice and care made my stay in Maastricht pleasant. I want to express my profound gratitude to Leon Kolenburg, Patricia von Schenckendorf, Kim van Hensberg and Sandra Habets all in the FHML for their help during my time of studies in Maastricht.

To my colleagues in the department of water and sanitation, Dr Peter Obeng, Dr Albert Duncan, Kwaku Oduro Appiah and Martha Osei-Marfo, thank you all for your encouragement and support. To my office mate and brother, Michael Anang I say thank you for your encouragement, advice and care towards my family when I am away. You are indeed a true brother.

To all my field assistants, Debbie, Elsie, Michael, Jonathan, Veronica, Lydia, Emma and Benjamin who helped me with data collection in the field I say thank you for the long hours we had to spend on the field and sometimes under uncomfortable conditions. To Denis of the Merln center at the University of Maastricht and Emmanuel of Cambridge University - England who helped me with my spectral analysis, I say a big thank you. To the staff of Komenda Edina Equafo Municipality (KEEA) planning and environmental health unit, Centre for Scientific and industrial research (CSIR), SGS and WRESP labs for assisting me with 
my field visits and laboratory analysis, I do appreciate the extra efforts you put in to make sure my results were indeed accurate.

Above all, I owe it all to the Almighty God for His mercies that are new every morning and that has brought me this far. I thank him for granting me the wisdom, good health, journey mercies and strength to undertake this research and bringing it to completion. You have always been faithful and I say Thank You Lord! 


\section{Author's resume}

Michael Oteng-Peprah was born in Takoradi in the Western Region of Ghana on $5^{\text {th }}$ of September 1979. He received his bachelor's degree in metallurgical engineering specializing in mineral processing from the Kwame Nkrumah University of Science and Technology, Ghana in 2004. After his undergraduate studies, he worked with the Golden star resources mining company as a trainee metallurgist on one of its gold treatment plants situated in Akyempim. It was during his time with the mines that he developed the passion for water and wastewater management. This led him to enrol for a master's programme at the Civil Engineering department of the Kwame Nkrumah University of Science and Technology in 2006. He completed the studies in 2008 obtaining an MSc in Water Supply and Environmental Sanitation. Just after his master's program at the Kwame Nkrumah University of Science and Technology in 2008, he received an Erasmus Mundus scholarship to study in Europe. He studied in four universities in Europe including University of Exeter in the United Kingdom, Wroclaw University of Technology in Poland, RWTH Aachen in Germany and Aalto University in Finland. He obtained a double degree in 2010; MSc Minerals and Environmental Engineering specializing in Process systems engineering and MEng Minerals and Geology specializing in mineral upgrading. His professional career started with the University of Cape Coast where he was first engaged as a part-time lecturer in the Department of Chemistry in 2011 and his appointment was regularized in 2013. Though he is officially in the Department of Water and Sanitation and due to his versatility, he sometimes lectures in the Industrial Chemistry unit. In 2016 he received a scholarship as part of the capacity-building project of the Netherlands Organization for International Cooperation in Higher Education (NUFFIC) to pursue his PhD at the University of Maastricht, Netherlands. His research interest includes water and wastewater management, hydraulic structures, process control and optimization and sanitation-related behaviour studies. 


\section{Publications}

\section{Included in thesis}

Oteng-Peprah, M., de Vries, N., \& Acheampong, M. A. (2020). Households' willingness to adopt greywater treatment technologies in a developing country - Exploring a modified theory of planned behaviour (TPB) model including personal norm. J Environ Manage, 254, 109807. doi:10.1016/j.jenvman.2019.109807

Oteng-Peprah, M., Acheampong, M. A., \& DeVries, N. K. (2019). Predicting greywater reuse for potable and nonpotable purposes in a developing country - a theory of planned behaviour approach. Desalination and Water Treatment, 142, 56-64. doi:10.5004/dwt.2019.23414

Oteng-Peprah, M., Acheampong, M. A., \& deVries, N. K. (2018). Greywater Characteristics, Treatment Systems, Reuse Strategies and User Perception-a Review. Water Air Soil Pollut, 229(8), 255. doi:10.1007/s11270-018-3909-8

Oteng-Peprah, M., de Vries, N. K., \& Acheampong, M. A. (2018). Greywater characterization and generation rates in a peri urban municipality of a developing country. J Environ Manage, 206, 498506. doi:10.1016/j.jenvman.2017.10.068

\section{Not included in thesis}

Anang, M. A., Oteng-Peprah, M., \& Opoku-Boadu, K. (2019). Extraction and Characterisation of African Star Apple (Chrysophyllum albidum) Seed Oil and the Adsorptive Properties of the Fruit Shell in Ghana. Int J Food Sci, 2019, 4959586. doi:10.1155/2019/4959586

Anang, M. A., Tulashie, S. K., Oteng-Peprah, M., Opoku-Boadu, K., \& Wofessor, A. (2014). Physicochemical assessment of the quality of water of the Amansure River in the Western Region of Ghana. Journal of basic and applied sciences, 1(2), 96-107.

Duncan, A. E., Oteng-Peprah, M., \& Osei-Marfo, M. (2014). Groundwater quality analysis on selected hand dug wells in the Cape Coast metropolis, Ghana: A case study of Abura. Journal of basic and applied sciences, 1(2), 23-30.

Oteng-Peprah, M., Marfo-Osei, M., Duncan, A. E., \& Sitsofe, A. A. (2014). Rainwater harvesting potential of University of Cape Coast Campus; a GIS approach. Paper presented at the 37th WEDC International conference on sustainable water and sanitation services for all in a fast changing world, Hanoi - Vietnam.

Drzymala, J., Kowalczuk, P. B., Oteng-Peprah, M., Foszcz, D., Muszer, A., Henc, T., \& Luszczkiewicz, A. (2013). Application of the grade-recovery curve in the batch flotation of Polish copper ore. Minerals Engineering, 49, 17-23. doi:10.1016/j.mineng.2013.04.024 

$0 \cup$

O 0

17

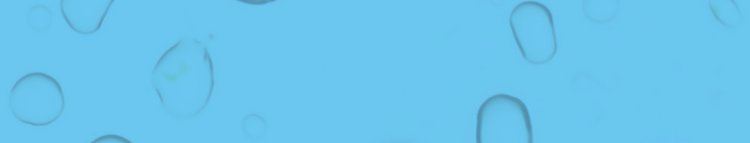<smiles>[CH-]</smiles>

○

I

0

50

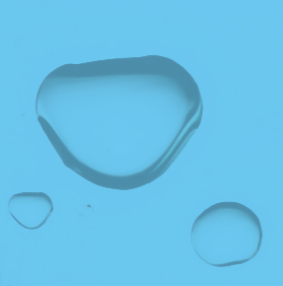

0

0

$\int 200$

ก?

ก<smiles>[AlH2]</smiles><smiles>[CH]1CCCC1</smiles>
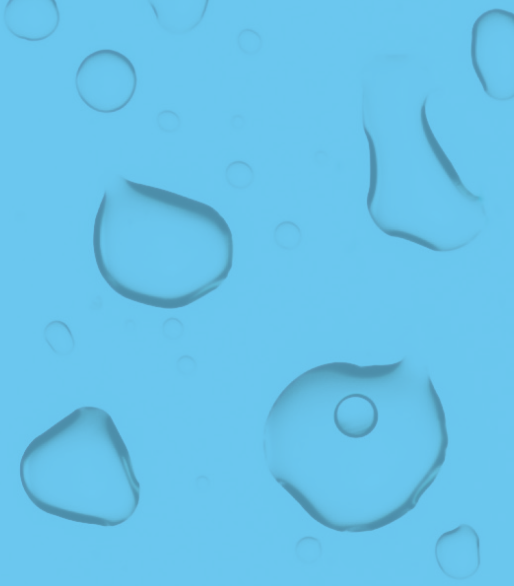

O

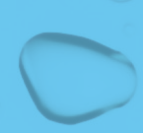

c

0

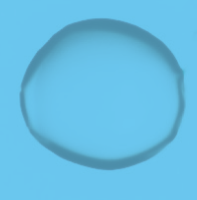

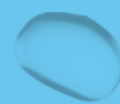

0

$\bigcup_{0} ?$<smiles>C1=CCC1</smiles><smiles>C1CCCC1</smiles>

0

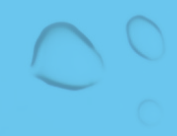

c

( 0

ก

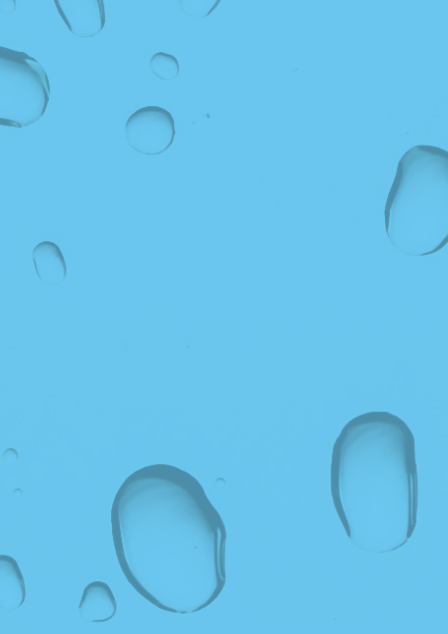

$0^{0} 0$

ก

กิ่

no

C

O

c

0 